\title{
Risks for cardiovascular disease in middle-aged women in different social environments
}

Carina Wennerholm



Department of Medical and Health Sciences Linköping University, Sweden Linköping 2017 
(c) Carina Wennerholm, 2017

Illustration/Design: Carina Wennerholm

Published article has been reprinted with the permission of the copyright holder.

Printed in Sweden by LiU-Tryck, Linköping, Sweden, 2017

ISBN 978-91-7685-497-6

ISSN $0345-0082$ 
Till Magnus, Johanna, Emil och Smilla

"Snöflingor är ett av naturens bräckligaste ting, men se bara vad de kan göra när de håller ihop"

Okänd 



\section{CONTENTS}

ABSTRACT

LIST OF PAPERS...........................................................................................

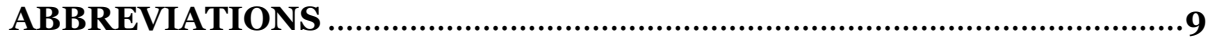

BACKGROUND ........................................................................................... 11

Social and economic changes in the society and public health ...............................11

Healthy and unhealthy environments ................................................................... 12

Upstream and downstream perspectives............................................................ 13

Promoting health equity.................................................................................. 15

Health inequalities in Europe............................................................................. 15

Genus perspective and health ......................................................................... 15

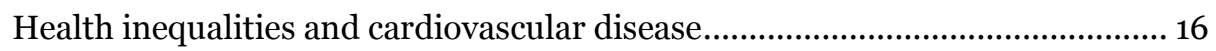

Social environment and cardiovascular disease .................................................. 16

Working life related to CVD ..................................................................................17

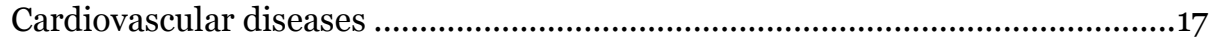

CVD nationally/internationally ……………………………................................ 18

Risk factors for CVD ........................................................................................... 19

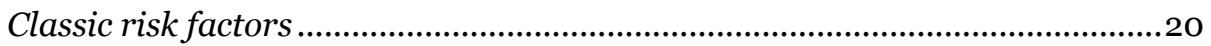

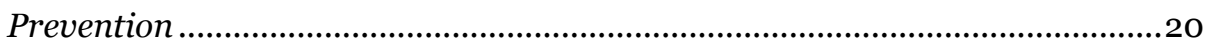

Psychosocial risk factors ............................................................................. 21

Personality traits and CVD ......................................................................... 22

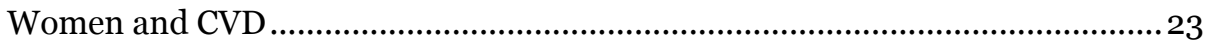

Model over upstream and downstream perspective in this thesis .......................24

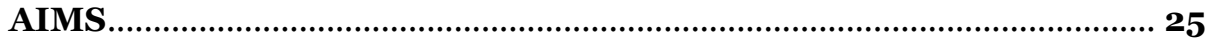

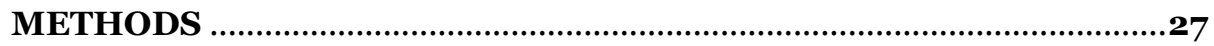

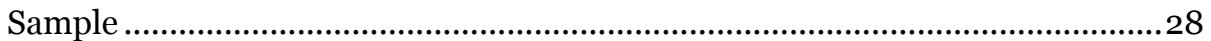



Questionnaire..................................................................................................... 29

The Health Care Register .............................................................................. 30

The Scottish Health Survey ....................................................................................3 


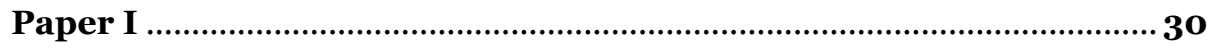

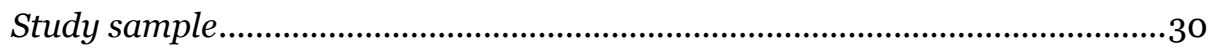



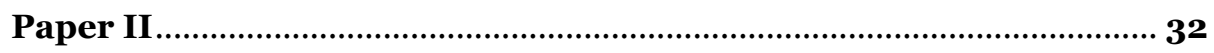

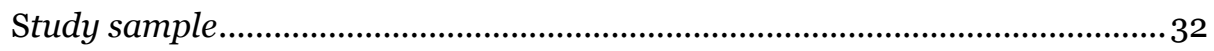

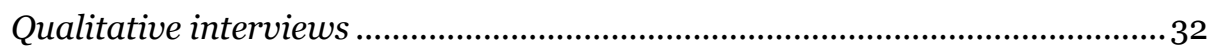



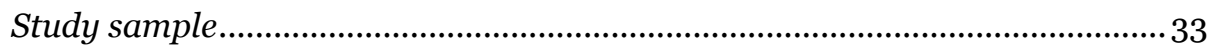

Diagnosis from the Health Care Register ......................................................... 33

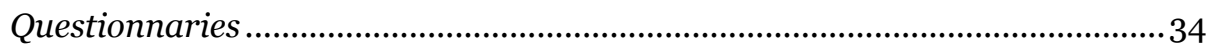

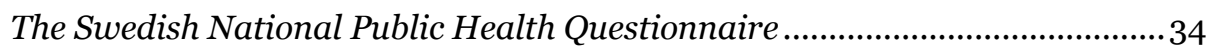

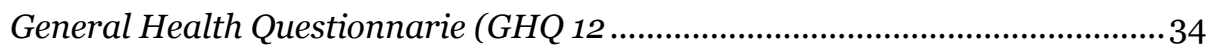

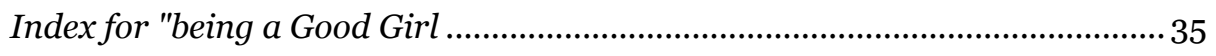

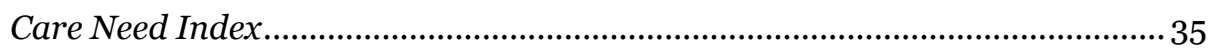

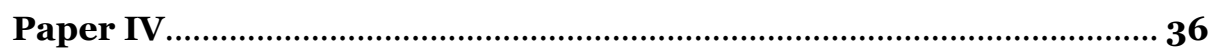

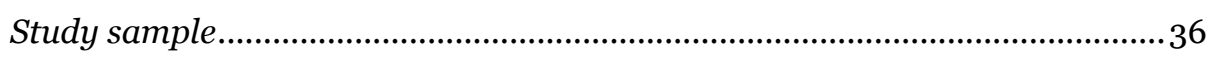

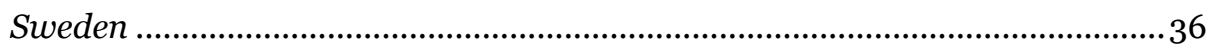



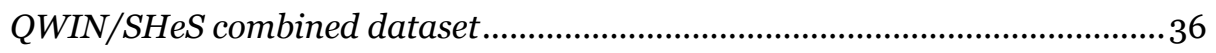

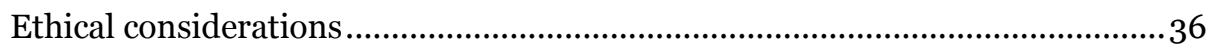





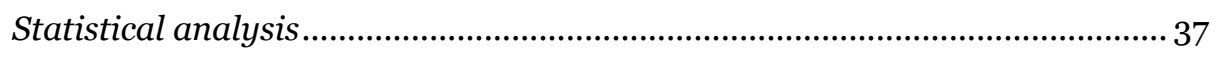

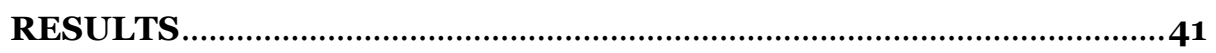



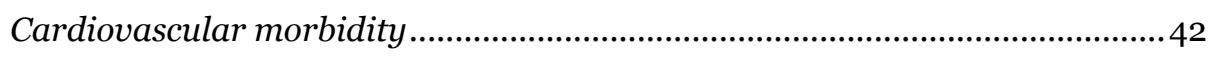

Cardiovascular mortality ........................................................................... 45

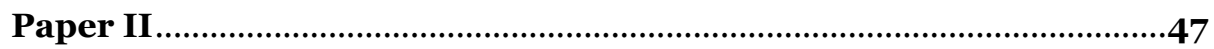

Themes and categories ................................................................................ 47

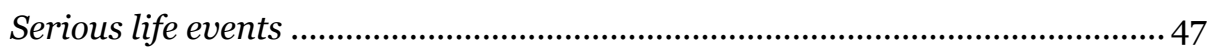



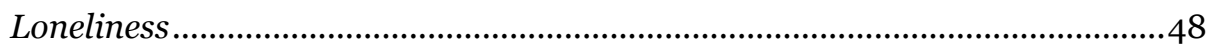

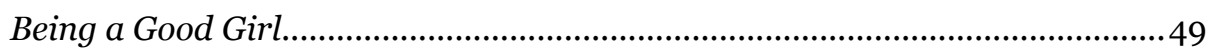

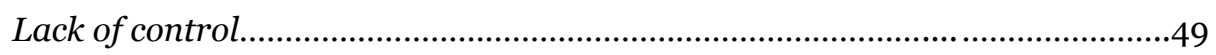




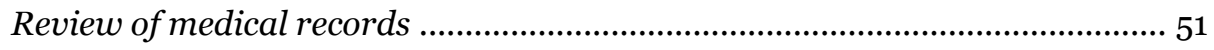

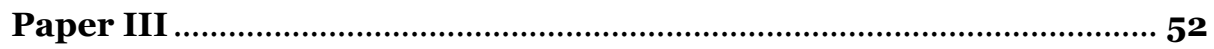

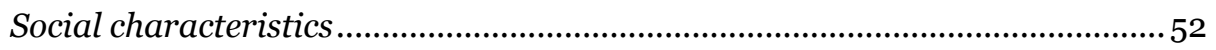

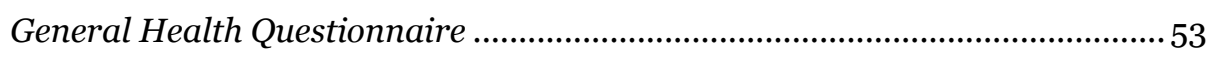

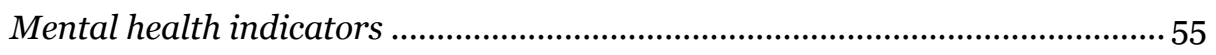

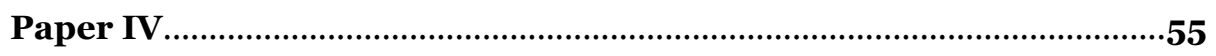

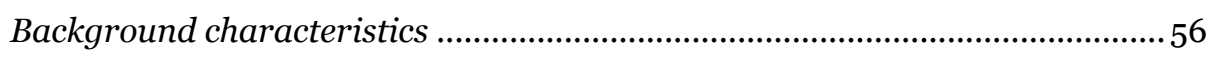

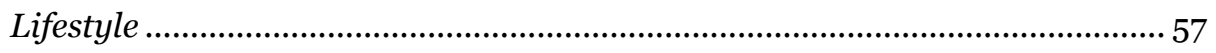

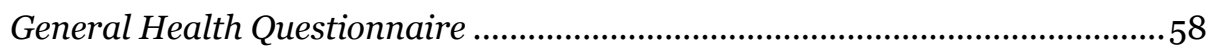



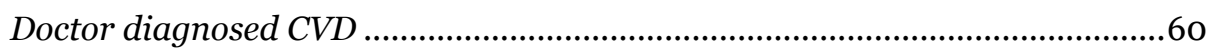



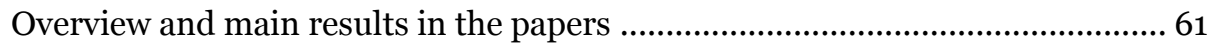

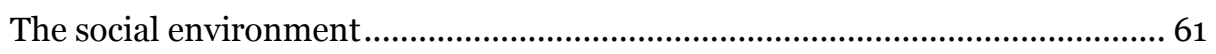

Twin cities - comparing a blue and a white collar city ...................................62

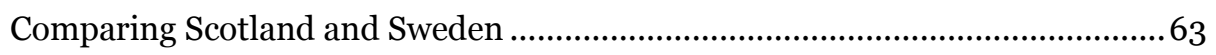



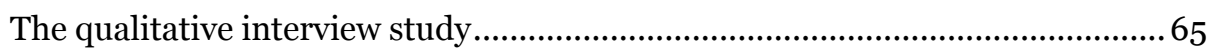

Risk factors for CVD and personality traits ....................................................66

Study Limitation and Methodological Consideration ........................68

The Health Care Register ...............................................................................6 68

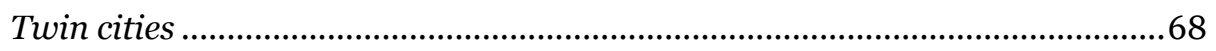

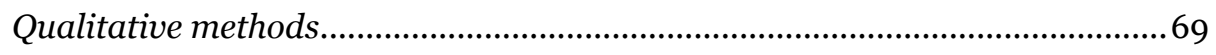

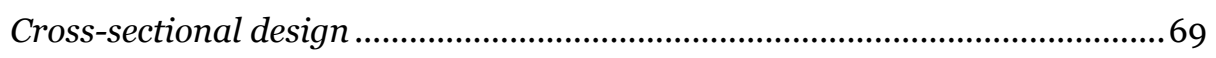

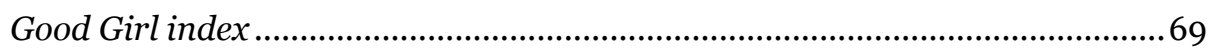

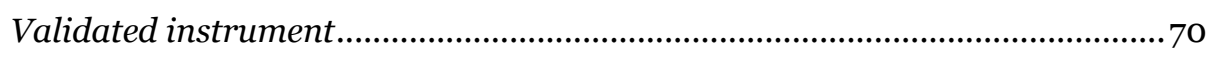

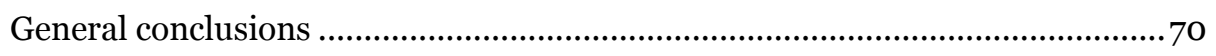

Implications for further research.......................................................... 71

POPULÄRVETENSKAPLIK SAMMANFATTNING ................................73

ACKNOWLEDGEMENTS ............................................................. 75

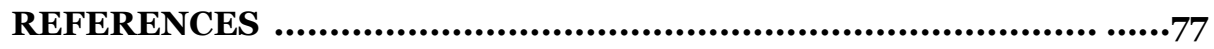


Contents 


\section{ABSTRACT}

Background: The importance of the social environment and human life conditions for public health was early recognized in community medicine. The society's hierarchical structures have consequences for health and the individual's position in that structure, has consequences for health. Despite major reductions in recent decades, cardiovascular diseases (CVD) is one of the leading causes of mortality and morbidity for both genders in all European countries.

Aim: The overall aim of this thesis was to increase our knowledge of factors in the social environment and of individual psychosocial factors that could explain why some women in working ages are affected by cardiovascular diseases. Further, to analyze cardiovascular risks and cardiovascular disease occurrence for middleaged women in different social environments.

Methods: The Swedish sample comes from the urban population in two major cities in a region in the south-east of Sweden, the Twin cities. According to their social history they could be labelled a blue collar and a white collar city. Cardiovascular morbidity data in all papers for the Twin cities was derived from a computerized population-based administrative Health Care Register (HCR). Data presented are cumulative incidence rates. Mortality data for ischemic heart diseases is based on official Swedish statistics.

In Paper II, women who had suffered an MI the past two years, were interviewed and their narratives were interpreted by qualitative content analysis. We identified all women $(n=46)$ under 65 years of age through HCR in the Twin cities and a strategic selection of $n=16$ women was made.

The QWIN-study is a cross-sectional survey to middle-aged women aged 40-65 years (Paper III). The sampling was made in the Twin cities. Besides a self-reported survey, data of health visits and diagnosis were also collected through a HCR. Finally, in Paper IV, we made a comparative study of cardiovascular risks of Swedish and Scottish middle-aged women. Swedish data were based on the QWIN-study and Scottish data comes from the Scottish Health Survey.

Results: In Paper I, the cumulative incidence of different cardiovascular diagnoses for younger and also elderly men and women were significantly different in the Twin cities. The occurrence rates were in all aspects highest in the population of the blue collar city in all ages and for both sexes.

The qualitative interviews of women after an MI, in Paper II, showed that many of these women had been exposed to extreme and repeated traumatic life events in their lives. Many had a cynical attitude towards others, felt lonely and experienced a lack of social support. Many of these women endeavored to "be a Good Girl", which was a special psychosocial phenomenon found.

Paper III demonstrated that women with a high level of the personality trait "being a Good Girl" reported significantly more psychological distress, anxiety and chest pain and had a higher incidence of the diagnose depression. Furthermore, the high level Good Girl group reported significantly more tiredness and "consider themselves to be pedantic". They were also less physically active and had a more sedentary lifestyle compared to the low level Good Girl group.

No increased incidence for various CVD-diagnoses were found in the high level Good Girl group. 
In almost all cardiovascular risks measurements in Paper IV, there were significant differences between the countries, favoring the Swedish women. Scottish women demonstrated a higher frequency of alcohol consumption, smoking, obesity, and low vegetable consumption, a sedentary lifestyle and also more psychological distress. For doctor-diagnosed CHD there were also significant differences, with a higher prevalence among the Scottish women.

Conclusions:

The social environment is of importance for cardiovascular risks and cardiovascular morbidity and mortality. This has been shown in Swedish Twin cities context and also in comparative studies between Swedish and Scottish women.

Cardiovascular morbidity and mortality risks and health behaviors and lifestyles seem to prevail in the blue collar city. The thesis gives strong implications for an upstream public health approach initiating long-term community intervention program in the blue collar city and among Scottish middle-aged women. 


\section{LIST OF PAPERS}

This thesis is based on the original publications, which are referred to in the text by their Roman numerals I-IV.

I. Wennerholm C, Grip B, Johansson A, Nilsson H, Honkasalo M-L, Faresjö T. Cardiovascular disease occurrence in two close but different social environments. International Journal of Health Geographics 2011, 10;5.

II. Wennerholm C, Jern M, Honkasalo M-L, Faresjö T. Life before Myocardial Infarction - A Qualitative Study of Middle-Aged Women. Health, 2014, 6, 2765-2774.

III. Wennerholm C, Johansson AK, Jaarsma T, Årestedt K, Nilsson S, Faresjö T. Personal traits of being a good girl and cardiovascular risk factors for middle-aged women. BMC Public Health; (submitted, Mars 2017).

IV. Wennerholm C, Bromley C, Johansson AK, Nilsson S, Frank J and Faresjö $\mathrm{T}$. Two tales of cardiovascular risks - middle-aged women living in Sweden and Scotland - a cross-sectional comparative study. BMJ Open, $2017 ; 7$ :e016527. 


\section{ABBREVIATIONS}

CHD Coronary Heart Disease

CVD Cardio Vascular Disease

CNI Care Need Index

HCR Health Care Register

SeHS The Scottish Health Survey

NHS National Health Services Scotland

WHO The World Health Organisation

IHD Ischemic Heart Disease

MI Myocardial Infarction

CWT Color Word Test

GG Being a Good Girl

GHQ General Health Questionnaire

ICD The International Classification of Diseases

IHD Ischemic Heart Disease

CI Confidence Interval

COREQ Consolidated Criteria for Reporting Qualitative Research

PHC Primary Health Care

OR Odds Ratio

RR Risk Ratio

QWIN Twin cities survey with women 40-65 years

UK United Kingdom

VDL Vårddatalagret 


\section{BACKGROUND}

\section{Social and economic changes in the society and public health}

The importance of observing human life conditions and the social environment when studying the development of public health was early recognized in community medicine (McKeown T, 1988). Other factors than hospitals and health care, such as sanitation, housing, nutritional habits, vaccines and education play an important role for public health development. For centuries, it has been evident that medicine also needs to include different social determinants to better understand disease occurrence, treatment, health outcomes, and prevention (Marmot M, Wilkinson R, 2006).

The Whitehall studies initiated by Sir Michael Marmot revealed how hierarchies and rankings among British civil servants had consequences in terms of people's mortality and life expectancy. The higher in the social hierarchy individuals find themselves, the longer they live. When health and risk of premature death were analyzed, Marmot emphasized the meaning of the concept of status. He also had an important social perspective on health (Marmot, 2015). Recently, it has become increasingly important in research to understand the relationships between health inequalities from the perspectives of economic, social and psychological influences on the population (Rostila M, Toivonen S, 2012).

The society's hierarchical structures has consequences for health, and the individual's position in that structure also effects health. Groups with a higher position in the social hierarchy, have more access to influence and money, better housing, jobs with higher status, while other groups with lower positions have access to fewer of these resources. Good health and a long lifeare strongly connected with a higher position in the hierarchical structures. The groups with the higher position enjoy better health, wherever we are in the social hierarchy, and those who are further down the hierarchy have a poorer health in relation to their position. In other words, health follows a social gradient (Siegrist \& Marmot, 2006).

However, there are some additional characteristics for the social gradient in health (ibid). With a few exceptions, there is a universal social gradient for nearly all diseases. Mortality and differences in health are most frequent in ordinary diseases, for example, cardiovascular disease, mental illness, obesity and type 2 diabetes, lung cancer, liver cirrhosis, and sexually transmitted diseases. Minor health differences have been observed in other types of cancer diseases, neurological diseases and gastrointestinal diseases. A few diseases also demonstrate the opposite social gradient; the higher the position, the higher the risks, breast cancer and asthma excepted (Marmot, 2015, Rostila \& Toivanen, 2012).

The social gradient varies between geographical areas, countries, genders and throughout the life course. The gradient is the steepest in childhood and adulthood, meaning that the social differences in health are the greatest during these periods of life. During adolescence and old age, the health differences are less evident. Gender differences in the social gradient of health are noticeable, with the gradient being steeper among men than women. 
There seems to be a variation in health inequality between countries, also in relatively homogenous countries such as the Western European economies (Marmot, 2015, Rostila \& Toivanen, 2012).

However, the differences in health also vary depending on how social position is defined. The most common indicators of social status are education, class and income, which are strongly related to education. A high level of education is often a prerequisite for a high status profession and a good income. Still, it is possible to achieve a high position in society without a long education, which means that social class or income does not always equal a high level of education. The way class, income and education affects health differs. Education is often believed to lead to increased knowledge about healthy living and lifestyle, while income affects health through the material resources it brings. The relation between the indicators social position and living conditions varies with gender, age and ethnic background, meaning that the consequences for health also vary (Edling \& Liljeros, 2010, Rosengren et al, 2009).

Though, there is also a social gradient in health in Sweden that is worsening, particularly in lower socioeconomic positions.

In Sweden, the social gradient has grown in the last 10 years, especially visible when measuring different type of mortality. Ill-health is almost consistently higher among people educated to elementary school level, compared to people with a college or university education (The Public Health Agency of Sweden, 2016).

\section{Healthy and unhealthy environments}

A culture's belief has both negative and positive effects on individual health (Helman, 2007). According to Hahn and Kleinman, "beliefs kill and beliefs heal". The beliefs and behaviors that contribute to stress and that are acquired by growing up in a specific society and its cultural values can be considered as a form of culturally induced stress or "cultural stress". This type of stress is also an example of the "nocebo effect", which means the negative effect of cultural beliefs and expectations on health .The "placebo effect" is the opposite, where beliefs instead lead to health (Hahn, 1997).

Nowadays, both socioeconomic conditions and environmental factors have been recognized as important public health. Factors that are important for public health are: safe and stimulating work, good sanitary conditions and spacious accommodation, access to healthy food in the local environment, proximity to good and safe school environments, proximity to well-functioning primary care, the design of the traffic environment, including good and affordable public transport (Diderichsen, 2002).

A comparison of public health in the Twin cities has been made possible, during the development from industrial to post-industrial era. As the social history and socioeconomic structure of the cities are radically different, they can be defined as a blue-collar city and a white-collar city. However, public health is remarkably different in these Twin cities to the detriment of the blue-collar city (Faresjö et al, 2007). 
Studies on gastrointestinal disorders, another disease group in the Twin cities, have revealed that knowledge of the occurrence of gastrointestinal problems in populations is better understood if viewed in a context where social environments are included (Grodzinsky et al, 2012).

Additionally, educational level and health in the local community in the Twin cities reveal that public health in local communities tends to reflect the social history and social heritage of the population. It was found that educational level appears to be a vital factor for an individual's perceived good health in a community (Faresjö, 2010). Mortality and life expectancy differ between communities, even when the socioeconomic situation is kept constant. Male workers in a suburb of Stockholm, Sweden (Sundbyberg), live about two years less than their colleagues in another suburb north of Stockholm (Solna), even though they share the same economic and social conditions. These two districts with the same economic and social conditions are located next to each other. The same trend applies to civil servants (Kölegård-Stjärne, 2005).

Another example can be found in Scotland. When socioeconomic factors have been kept constant, there are still disparities in mortality between people living in Glasgow versus Edinburgh. Glasgow researchers Sally McIntyre and Anne Ellaway have highlighted the importance of the physical and social environments, such as infrastructure, schools, medical facilities, access to shops, but also proximity to nature areas, which have been shown to be factors affecting health. An unequal health situation in the population of the two cities was revealed, where the people of Glasgow were the unhealthiest with more ill-health and worse public health (MacIntyre S, 2002). "Contextual factors" is the concept used for these aspects in the environment, in contrast to "compositional", meaning social and economic conditions (McIntyre, Ellaway, 2000). Community planning and political decisions, especially on a municipal level might influence these contextual factors (ibid). Furthermore, researchers in Scotland and Canada have performed comparative studies of equal cities.

These studies have found that people free of the inhesion of social class suffer more from diseases and experience lower self-perceived health in Glasgow, Scotland, than in Hamilton, Canada (Wilson K et al, 2010).

A recent study reported that socioeconomic position and infrastructure in suburbs are of importance to health. A high level of social and cultural capital and good social infrastructure in an area affect health positively. On the other hand, a low level of social capital and a lack of social infrastructure affect health negatively (Schule, SA, et al 2015).

\section{Upstream and downstream perspectives studying determinants of health}

The role and importance of social and physical environment for health, the effect of place, and the question of whether we should focus on places or people are still relevant matters for public health science (Macintyre et al 1993, Macintyre et al 2002, Diez-Roux et al 1997, Cummins et al 2007). A general conclusion of this issue is that who you are and how you live your life, as well as where you live your life, are of importance for your health (Picket K, Pearl M, 2001). 
There are by tradition two perspectives for studying determinants of health in public health and social medicine; one focuses on "upstream" factors and the other on "downstream" factors. The upstream approach emphasizes social, ethnical, cultural and economic factors in the community. This perspective, individual differences in lifestyles, and living conditions are not the only important factors in explaining health differences between individuals; social, ethnical, cultural and economic factors in the community will also affect public health and generate health differences between individuals (Wilkinson R, 1997, Wilkinson R, 2005). A defined population in one geographical area could present a particular distribution of risk factors that varies distinctly from those found in a similar population but in another geographical area (Rose G, 1985, Rose G, 2001).

The downstream perspective in health care research and clinical practice predominantly focuses on the individual and on individual living conditions and lifestyles. According to this downstream perspective, disease occurrence in an individual should either be related to environmental exposure or be genetically inherited. However, it is not unusual to combine these two perspectives in public health research (Susser M, Susser E 1996, Vågerö D, 2006).

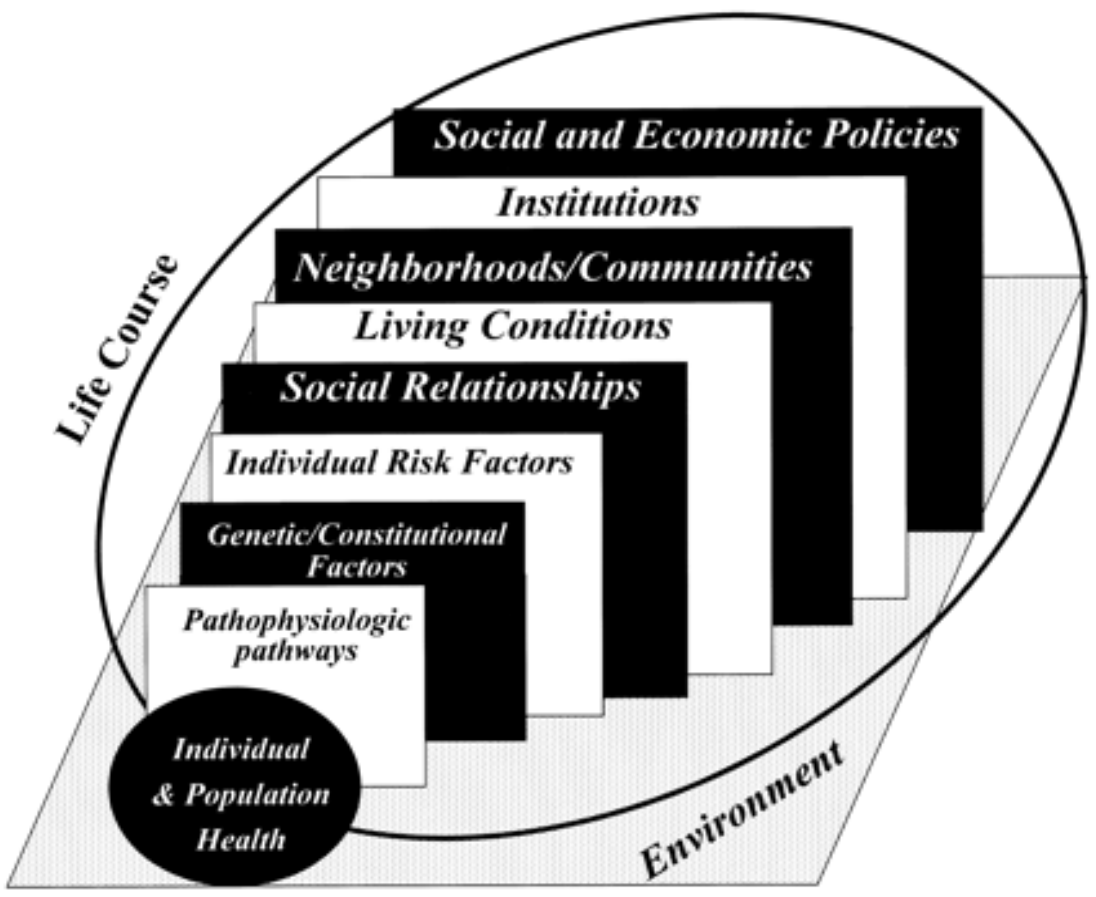

Figure 1. Upstream and downstream determinants of public health. Model of factors influencing health by Kapland, 2004, p. 125. 


\section{Promoting health equity}

In the final report by the WHO "Commission for Social Determinants of Health" in 2008, it was pointed out that inequality in health could be decreased by influencing social determinants of health at different levels (WHO, 2008). It is of importance to address the conditions in which people are born, grow, live, work and age, which are key determinants of health equity. In turn, these conditions of daily life are influenced by structural drivers, such as economic arrangements, distribution of power, gender equity, policy framework and the values of society. A lifelong approach to health equity is essential. Advantages and disadvantages throughout the life-course accumulate.

It all starts with the important early stages of life - early child development and pregnancy - continues with school, the working life transition, employment and conditions at work, and physical and social environments affecting older people. Health becomes progressively better the higher the socioeconomic position of people and communities, explained by the social gradient of health. Policies must be designed to act across the whole gradient and address the people who are the most vulnerable (Frank et al, 2015, Marmot, 2015).

Universal policies are needed to achieve both these objectives, implemented at a level and intensity of action that proportionate to need, that is to say proportionate universalism. The WHO Commission for Social Determinants of Health concluded that the conditions in which people are born, grow, live and age, and the inequalities in power, money and resources that give rise to these conditions of daily life are the reasons and the roots to inequalities in health. It said: "Social injustice is killing people on a grand scale" (WHO, 2008).

\section{Health inequalities in Europe}

There are persisting and substantial health inequalities across Europe, countries with close to the best health are included, with the narrowest health gaps in the world. The reason is a long and sustained period of improvement in people's way of life, increasing affluent socially cohesive societies, health services and highquality education that grew from a solid and developed welfare state.

There is evidence showing that conditions have been created for people to have reason to value their lives, and freedom to lead their lives. The result of all this are remarkable health gains (WHO, 2008).

Nevertheless, the social, economic and health developments have not been shared equally by everyone. Improvements in social and economic circumstances have occurred in all countries, but health has suffered and differences remain, mostly in Eastern Europe. Even more affluent countries have increasingly seen inequalities in people's life conditions and declining social cohesion and social mobility. Health inequalities are not diminishing or reduced. Instead they increase in many countries, as a likely result of these changes (ibid).

\section{Genus perspective and health}

"Women are sicker but men die quicker"- the so-called gender paradox in health (Rostila \& Toivanen, 2012), meaning that women report more ill- health but have longer life expectancy than men. It is difficult to know if this is due to biological or social interaction, or if it is a combination of both. The causes for illness may linked to different factors, depending on whether the person is male or female.

Diseases and causes of death stem from several types of health concerns, as well as various determinants of health. For instance, factors that cause repetitive 
strain injury are not the same as the ones that cause death at younger ages. Women live longer than men, in the view of the health paradox, but have more ill- health. The causes of mortality vary greatly from the causes of ill-health (ibid).

Both sex and gender have an important effect on the health of women, which needs to be considered when developing suitable strategies for prevention and treatment of ill-health and health promotion. Biological differences and gender inequality, both alone and in combination, can increase exposure or vulnerability to a certain risk among women. The manifestation, severity and consequences may differ and are not always identified, but could lead to a limit in women's access to resources and to health care information and services (WHO, 2009).

All the social determinants of health can affect the gender differently according to gender equality. There are fundamental social variations in addition to biological sex differences in how men and women are treated and the resources and flexibility they have. In all societies these gender relations affect health to varying degrees and should be remedied (WHO, 2008).

\section{Health inequalities and cardiovascular disease (CVD)}

For the last 40 years, researchers have reported, that there is an inverse relationship between socioeconomic status and CVD (Kaplan 1993, Clark et al 2009). Individuals with low socioeconomic status living in industrialized countries have a higher incidence and mortality (Alboni 2003, Kyndaron 2011). Previously, individuals at higher socioeconomic levels were affected (Marmot 1978). Social factors such as low socioeconomic status, including a poor residential area, low educational level, a low-status job, and low income predispose for CVD (Perk et al 2012), especially in working ages (Reinier K, 2011). A higher presence of classical risk factors in low socioeconomic groups only partly explains the difference (Wennerholm et al 2011).

Low socioeconomic status has been demonstrated to be associated with higher rates of coronary disease in industrial countries globally. In 52 countries, the strongest relation to increased risk for acute myocardial infarction was the socioeconomic status marker low education. Around half of the increased risk associated with low education was due to modifiable lifestyle factors. In high-income countries the effect of education was more marked, compared to low- and middleincome countries. This is likely to be a reflection of different phases in the epidemiological transition (Rosengren et al, 2009, Veronesi et al, 2016).

\section{Social environment and cardiovascular disease (CVD)}

Neighborhood of residence has been suggested to affect cardiovascular risk above and beyond personal socioeconomic status (Gerber et al 2010, Chaix et al 2010). In a multilevel analysis it was found that neighborhood income predicted individual systolic blood pressure, but it was concluded that both individual and neighborhood socioeconomic status and race were linked to cardiovascular risk disparities as early as in adolescence (McGrath et al 2006, Gerber et al 2008).

People living in environmentally disadvantaged suburbs and neighborhoods in the Stockholm region are more vulnerable to, and suffer more severe myocardial 
infarctions. These contextual differences were evident when people from the same social class were compared (Köhlegård-Stjärne M, 2005).

The decisive part of social, economic and cultural factors responsible for such a frequent disease as CVD is more noticeable when assessing data on women. The recent societal evolution has led to striking upsurges in labor force participation for women, and also changes in their economic role. In the past 20 years, the political and economic situation in Europe has undergone unique changes. When the epidemiology of CVD and its risk factors in European women are described, this notable evolution cannot be ignored (Panico et al, 2010).

From an anthropological perspective, research reveals that values and behaviors leading to heart disease can be built into a culture. The cultures values and rewarded behavior, may be of such a nature, that it might lead to heart disease. Meaning that heart disease is a disease giving you status in the social hierarchy. This means, which the individuals affected of heart disease in such culture, have suffered, been strong and endured, and that gives you social status (Honkasalo, 2009).

\section{Working life related to CVD}

The relationship between work-related stress and myocardial infarction indicates that the risk for suffering MI increases with $50 \%$ for individuals affected by workrelated stress (Kivimäki et al 2006). Previously, extensive research has supported the relationship between negative stress in working life and myocardial infarction (Levi et al 2000). Work-related stress with high demands and lack of control is a risk factor (Kivimäki et al 2006, Johnson et al 1996).

Furthermore, there is a relationship between the risk of CVD and a low level of control over one's job (Bosma et al, 1997). Employees, both men and women, who report adverse occupational exposure such as job strain or lack of decision latitude have an increased risk for ischemic heart disease (IHD). Effective organizational interventions can influence several work environment factors. Psychosocial interventions and good evaluation methods are significant steps in this research field. For some of the working conditions that are developing in the modern working world, new research on IHD will be required (Theorell et al, 2016).

\section{Cardiovascular diseases}

One group of disorders of the heart and blood vessels are included in the disease group cardiovascular disease (CVDs). The division of the disease group CVD into subgroups can be described as follows.

- Coronary heart disease - a disorder of the blood vessels providing the heart muscle with blood.

- Cerebrovascular disease - a disorder of the blood vessels providing the brain with blood.

- Peripheral arterial disease - a disorder of blood vessels providing the arms and legs with blood.

- Rheumatic heart disease - injury to the heart muscle and heart valves from rheumatic fever, affected by streptococcal bacteria.

- Congenital heart disease - deformities of the heart structure present at birth. 
- Deep vein thrombosis and pulmonary embolism - blood clots in the leg veins, which can displace and move to the heart and lungs.

Often, the underlying disease of the blood vessels does not display any symptoms. Unfortunately, the first warning of the underlying disease could be a heart attack or a stroke. Pain or discomfort in the center of the chest or pain or discomfort in the arms, the left shoulder, elbows, jaw, or back are the main symptoms of a MI.

Additional symptoms include difficulty breathing or shortness of breath, feeling sick or vomiting, feeling light-headed or faint, breaking into a cold sweat, and becoming pale. Shortness of breath, nausea, vomiting, and back or jaw pain are more likely symptoms in women (WHO, 2017).

A sudden weakness in the face, arms, or legs, usually on one side of the body, are the most common symptoms of stroke. Additional symptoms include unexpected onset of numbness in the face, arm, or leg, particularly in one side of the body. Still more symptoms include difficulty speaking or understanding speech and confusion, trouble seeing with one or both eyes, trouble walking and feeling dizzy, loss of balance or coordination, severe headache for no reason, and fainting or unconsciousness (ibid).

\section{CVD prevalence nationally/internationally}

The number of deaths per year due to CVD is 17.6 million. One in 10 individuals aged 30-70 die from CVD and 31\% of all deaths are due to CVD (World Heart Federation, 2017). This makes CVD the number one cause of death globally, more people die annually from CVD than from other causes. Coronary heart disease was responsible for 7.4 million deaths and 6.7 million were due to stroke. Over 3/4 of all CVD deaths occur in low- and middle-income countries, (WHO, 2017).

During the last 20 years there has been a substantial decline with 50 percent in mortality related to cardiovascular disease. The decrease involves both men and woman in all industrialized countries (Weinehall 2003, Gulliksson et al, 2009, The Public Health Agency in Sweden, 2016). However, there are major regional differences. Myocardial infarction (MI), which is the diagnosis that leads to most deaths in the disease group, is much more common in Northern Europe than Southern Europe. In eastern Europe, mortality due to MI is even higher and increased sharply after the fall of the Soviet Union, especially among men (Weider et al, 2002). Still, life expectancy is lower in these countries than before the fall of the Soviet Union (Bobak et al, 2004). In the Nordic countries the differences are small, with one exception. Finland has a significantly higher cardiovascular mortality rate than other Nordic countries (Nichols et al, 2013)

Recent studies have indicated that in Europe, mortality from cardiovascular disease falls steadily, except for Russia, where the mortality rate is 10-15 times higher than in Italy, France and Sweden.

In Poland, Hungary and Scotland, the downward trend is less promising than in other parts of Europe (Newton et al 2015, Bertuccio et al 2016). Historically, mortality in cardiovascular disease has gradually increased from the 1920 s to the $1960 \mathrm{~s}$ 
in Sweden. The upward trend then leveled out before there was a substantial decline of $50 \%$ in the last 20 years. The decline applies to both men and women (Weinehall 2003, Gulliksson et al, 2009). The gap between the incidence of acute MI and survival has decreased in Sweden, but varies throughout the country (The Swedish National Board of Health and Welfare, 2015).

Cardiovascular disease (CVD) remains the primary cause of death in Sweden, even though improvements in medicine have been made (Nichols et al, 2013). In 2013, the incidence of MI in Sweden varied for men (522/100000) and women (344/100000). Age and gender have a great impact on incidence, and environmental factors also play a part. As an example, for men in Sweden aged 45 to 74 with 9 years of education or less, the incidence was $40 \%$ higher than for those with 10 years of education or more. For women, the incidence was even higher, $60 \%$ for those with less education (The Swedish National Board of Health and Welfare, 2015). The risk of developing a first myocardial infarction has not declined for women, but the risk of a recurrent event has decreased, although it not as much as in men. In general, the decline of CVD is stronger among men than among women, which has resulted in a convergence between men and women in life expectancy (Public Health in Sweden, 2016).

\section{Risk factors for CVD}

\section{Classic risk factors}

In relation with CVD, the Framingham investigators were the first to mention the term "risk factors". Epidemiological studies, primarily Framingham and

the Seven Countries Study, identified several risk factors that cause the development of CVD (Kannel et al , 1961, . Keys et al 1972).

The main modified risk factors for CVD are high blood pressure, hyperlipidemia, smoking, alcohol consumption, physical inactivity, overweight, unhealthy food, diabetes mellitus, low levels of fruit intake, and psychological factors. The main nonmodified risk factors for CVD are increased age, heredity for CVD, sex and ethnicity. According to the WHO, the modified risk factors were assessed to be the cause of $75 \%$ of CVD-morbidity. The hereditary factors are, however, of less importance (Mendis et al, 2011, Yusuf et al, 2004, Anand et al 2008).

There is an increased risk for CVD in women who smoke, compared to male smokers. The same conditions apply for diabetes (Banzer et al, 2004).

Individuals with diabetes have an intensified risk for developing CVD compared to those without diabetes. Individuals suffering from both diabetes and obesity are at an even higher risk (Banzer et al, 2004, Fox et al, 2008).

Mortality from CVD and hypertension is strongly related, and various pathophysiological mechanisms associate hypertension with the development of atherosclerosis (Andre-Petersson et al, 1999). Total cholesterol is positively associated with mortality due to CVD for both middle-aged and old age individuals. However, modifiable risk factors are highly incorporated and answerable for a great part of all CVD risks (Truthmann et al, 2015).

\section{Prevention related to classic risk factors}

The occurrence of a cluster of risk factors in individuals, such as tobacco use, physical inactivity, unhealthy diet and obesity, harmful use of alcohol, hypertension, 
diabetes and hyperlipidemia, is commonly the root of the cause for stroke and MI (Perk, 2012).

The most important behavioral risk factors for CVD are physical inactivity, unhealthy diet, harmful use of alcohol, and tobacco use. The symptoms based on these risk factors manifest themselves in the individual as overweight and obesity, raised blood pressure, raised blood lipids, and raised blood glucose. In primary care facilities, these "intermediate risk factors" can be measured, and they signify an increased risk of developing a MI, stroke, heart failure, and other difficulties. Regular physical activity, cessation of tobacco use, reduction of salt in the diet, consuming fruit and vegetables, and avoiding harmful use of alcohol reduce the risk of cardiovascular diseases. Nevertheless, drug treatment of diabetes, hypertension and high blood lipids may be necessary to reduce the cardiovascular risk and thereby prevent MI and stroke. For making it easier to do healthy choices, it `s required, to create conductive environments by health policies through more accessible and inexpensive facilities, that are vital for motivating people to regulate and endure healthy behavior. Furthermore, there are several underlying determinants of CVD, or "the causes of the causes".

These are the major influences pushing social, economic, and cultural change globalization, urbanization and an aging population. In addition, poverty, stress and hereditary factors are other determinants of CVD (Mendis et al, 2011, WHO, 2017).

The WHO have identified that cost-effective interventions are feasible for preventing and controlling cardiovascular diseases, even in low-resource settings. Two types of interventions are included, population-wide and individual, namely, upstream and downstream perspectives. A combination of both perspectives is recommended to reduce the peak of the cardiovascular disease burden.

Reducing CVD through interventions with an upstream perspective could involve providing healthy school meals for children, strategies to reduce harmful use of alcohol, widespread tobacco control policies, taxation of foods that are high in fat, sugar and salt, increase physical activity by building walking and cycle paths. From a downstream perspective, the individual level, primarily prevention before the first strokes and MI is recommended. Individual health care interventions to individuals at a high total cardiovascular risk or who are exposed to significant single risk factors, e.g., hypertension and hypercholesterolemia should be focused upon. Secondary prevention should be targeted at those with established disease and who are on medication, e.g., aspirin, beta-blockers, angiotensin-converting enzyme inhibitor and statins, (including treatment for diabetes mellitus). Nearly $75 \%$ of recurrent vascular events can be prevented. Interventions used together with smoking cessation give the highest benefit. Expensive interventions are sometimes necessary for treatment of CVD.

The most commonly used ones are balloon angioplasty, coronary artery bypass, valve repair and replacement, heart transplantation, and artificial heart operation. To treat some CVDs, medical devices are required, including pacemakers, prosthetic valves, and patches for closing holes in the heart (WHO, 2017). 


\section{Psychosocial risk factors for CVD}

Classic risk factors such as high blood pressure, hyperlipidemia, smoking and diabetes only partly explain why people develop CVD. The importance of and focus on psychosocial risk factors for the disease is increasing (Hallman et al 2001, Mendis, 2011, Perk et al, 2012). The majority of risk factors, besides sex, age and genetics can be avoided.

These are related to lifestyle or social circumstances and could account for almost 2/3 of all cardiovascular diseases (Mendis, 2011, Yusuf et al, 2004). Psychosocial risk factors are highly associated with myocardial infarction. The Interheart Study stated that these factors are of greater importance than hypertension (Yusuf et al, 2004).

The key factors accounting for $90 \%$ of the risk of MI also include psychological factors (Yusuf et al, 2004, Anand et al 2008). Other risk factors for MI are stress, depression, and lack of locus of control (Rosengren et al, 2004, Denollet et al, 2000). Physiological risk factors might arise from psychosocial stress (Kuper, 2002), and these are also related to the development of atherosclerosis and high blood pressure, thus enhancing the risk of cardiovascular mortality (Cramer, 1991). Psychosocial risk factors increase the risk of developing and worsening the prognosis of CVD, and the psychobiological mechanism is well described in the literature (Perk et al, 2012, Kop WJ, 1997, Gonzalez et al, 2009). Clusters of psychosocial risk factors in different socioeconomic groups are present in the individuals as well. For instance, people in lower socioeconomic status groups, both men and women, may experience more chronic stress. They are likely to be more socially isolated, hostile and depressed (Denollet et al, 2010, Nabi et al, 2008).

Psychosocial factors might be linked to CVD risks by the mechanisms from an unhealthy lifestyle, such as unhealthy food choices, more frequent incidence of smoking, less physical activity, increased health care consumption, and low adherence to cardiac medications and behavior-change recommendations. While social support seems to be a protective factor, stress in the family and the close social environment, such as conflicts and family crises, particularly affects women's risk for CVD (Perk et al 2012, Low CA et al, 2010).

In addition to being a risk factor for CVD, psychological symptoms such as depression and anxiety increase the risk and worsen the prognosis for CVD. Anxiety is a key component of how stress leads to ill-health (Suinn, R 2001). It could prolong the stress exposure and maintain it on a high level, even if the person is not objectively exposed to stressors (Perk et al 2012, Sapolsky 1994). Major life events such as violence and abuse, diseases, or even losing one's job, cause stress in the body and therefore increase the risk of cardiac events (Gonzalez et al, 2009, Andersen et al 2011).

\section{Personality traits and CVD}

Personality and attitudes also play roles for potential CVD risk factors. Being cynical and hostile and having maladaptive social relations and a suppressed anger increases the risk of CVD. Distressed personality or type-D personality has a general tendency to negative affectivity, which is a chronic risk factor compared to the 
more episodic states of depression and anxiety (Perk et al 2012, Denollet et al 2010). Being positive and optimistic are protective factors (Tindle et al 2009), as is a forgiving attitude (Lawler et al 2003).Among the many potential risk factors for CVD, several personality traits and personality characteristics have been considered. Individuals how easy likely to adopt optimal health behavior described as 'conscientious' (Deary et al, 2010, Bogg et al, 2013).

Extraversion, neuroticism and agreeableness are personality traits that may influence people's emotional and social life, including sensitivity to negative experiences, (Watsonet al, 2014), reduced capacity to adjust to difficult and changing life circumstances, and lack of social support (Connor-Smith et al, 2007). For instance, personality traits such as a type A behavior pattern and a type D personality, as well as hostility and anger proneness, have been indicated to be risk factors for CVD. Type A behavior, also called "coronary prone" behavior pattern, comprises competitive and ambitious behavior, impatience, intolerance and hostility. Links between type A behavior and CVD risks have been described earlier in many studies (Jenkins et al, 1974, Rosenman et al, 1976).

However, more recent studies have questioned these findings (Shekelle et al, 1985, Tunstall-Pedoe et al, 1997). A meta-analysis has also reported that type A behavior has no influence on the development of CVD (Myrtek, 2001). A type A personality may be a risk marker for psychological distress, even though there is minor indication for a prognostic factor in patients with CVD (Kuper et al, 2002, Cramer, 1991).

Type D personality (which includes distressed behavior) involves a permanent predisposition to experience an inhibition of self-expression in relation to others (social inhibition) and a broader spectrum of negative emotions (negative affectivity). Even after adjustment for depressive symptoms, stress, and anger, type D personality has been shown to predict poor prognosis in patients with CVD (Denollet et al, 2010). A relationship between depression and MI has been found, and it is proven that patients with depression have an adverse prognosis (Barth et al, 2004, van Melle et al, 2004).

Positive factors for not becoming ill, i.e, salutogenetic factors, have been poorly studied in relation to CVD, compared to patogenetic factors. In the Whitehall IIstudy (Nabi et al, 2008), potential salutogenetic factors related to personality were not associated with CVD incidence either in men or women.

Nevertheless, some studies have indicated that better emotional vitality, showed as a sense of vitality, positive well-being, and emotional control, are related to a decreased risk for CHD in both genders (Boehm et al, 2016).

Mastery and self-esteem are psychological resources demonstrated to have a strong protective effect on CVD, even after adjustment for traditional risk factors, as well as depressive symptoms. Besides, hopelessness is an independent risk factor for CVD (Lundgren et al, 2015). In the Color Word Test (CWT), maladaptive behavior in individuals has been shown to constitute a higher risk of CVD, as perceived in hypertensive men in the study "Men born in 1914". The same study showed that hypertensive men in a stressful situation and with a maladaptive behavior have a nearly three-fold risk to be affected by CVD (Andre-Petersson et al, 1999). 


\section{Women and CVD}

CVD is the most common cause of death in both men and women. The WHO have reported that CVD is the most forgotten health problem among women, both in developing and industrialized countries. Thus, CVD kills more women than the total number of women dying from cancer, HIV/AIDS, tuberculosis and malaria combined (Schenk-Gustafsson, 2008).

It is the main cause of death in men in eastern Europe and women in Oceania, and the least common in both sexes in the high-income Asia-Pacific region. Globally, the average age-standardized CVD death rate has fallen over the past two decades. Declines in rates of death attributable to both IHD and cerebrovascular diseases accounted for most improvements. None of the changes are attributable to CVD as it increases rapidly in women after the age of 70, surpassing the proportion among men. This trend is driven predominantly by stroke deaths and explains the slightly higher proportion of death attributable to CVD for women overall (Roth et al, 2015).

The burden of CVD, particularly myocardial infarction (MI), the main CVD, is increasing in middle-aged women, and is said to be one of the most serious neglected health problems in the world. In research, women are underrepresented and there is a need for a more profound and gender-specific knowledge about women and CVD (Maas et al, 2010, Wenger et al, 2010).

However, gender-specific data focusing on CVD is becoming increasingly available (Oestreicher Stock \& Redberg, 2012). The risk of middle-aged and elderly women suffering a myocardial infarction is often underestimated, as it has been believed to be a male disease. For many years, despite an international focus on cardiovascular disease in women, overall mortality has not decreased among women, especially among younger women (i.e. those who have not entered menopause). Cardiovascular disease in Sweden does not decrease in women, but it does in men. Still, men have a higher incidence of the disease. It also affects the overall life expectancy, and the gap between men and women has decreased (The Swedish National Board of Health and Welfare, 2015).

Women living in Japan and Italy have the highest life expectancy, but Swedish women also live long (Schenk-Gustavsson, 2008).

Life expectancy for Swedish women is on average 84 years (SCB, 2016). Mortality in connection with MI increases among women in USA, but not in men. In Europe CVD harvest $56 \%$ of all women's lives.

From an international perspective, mortality rates due to CVD in Sweden, are still high, compared with, e.g. countries in the south of Europe. The Mediterranean lifestyle is probably the reason for this difference. The areas around Barcelona see the lowest number of $\mathrm{MI}$ in women globally, which might be due to hereditary factors (Schenk-Gustavsson, 2008). In general, women fall ill about 10 years later than men and the reason for this is still unknown. It has been hypothesized that women are protected by estrogen until menopause, but differences in smoking habits and diet may also be of importance (Anand et al, 2008). 
Many factors referred to as sex-based differences, involve physiological, anatomic and genetic factors, along with delays in recognizing symptoms, underutilization of diagnostic tests and treatments. Inspired by increasing evidence of differences in outcomes and clinical presentations between men and women, essential biological gender differences in vascular function and the underlying pathologic process, has only started to be clarified. However, we are starting to see improvements in outcomes for women, a decline in complication rate after coronary revascularization. This has happened through, for example, the advent of new techniques, such as radial access for cardiac catheterizations and improved involvement of women in clinical trials. A great progress has been made in understanding gender-related differences in CVD, but a great deal more needs to be done to improve the prevention of CVD in both men and women (Oestreicher Stock \& Redberg, 2012). A recent study showed limited gender differences in CHD treatment. The largest gender differences were seen in less educated and elderly patients. The gender gap declined with falling age and higher education (De Smith et al, 2016).
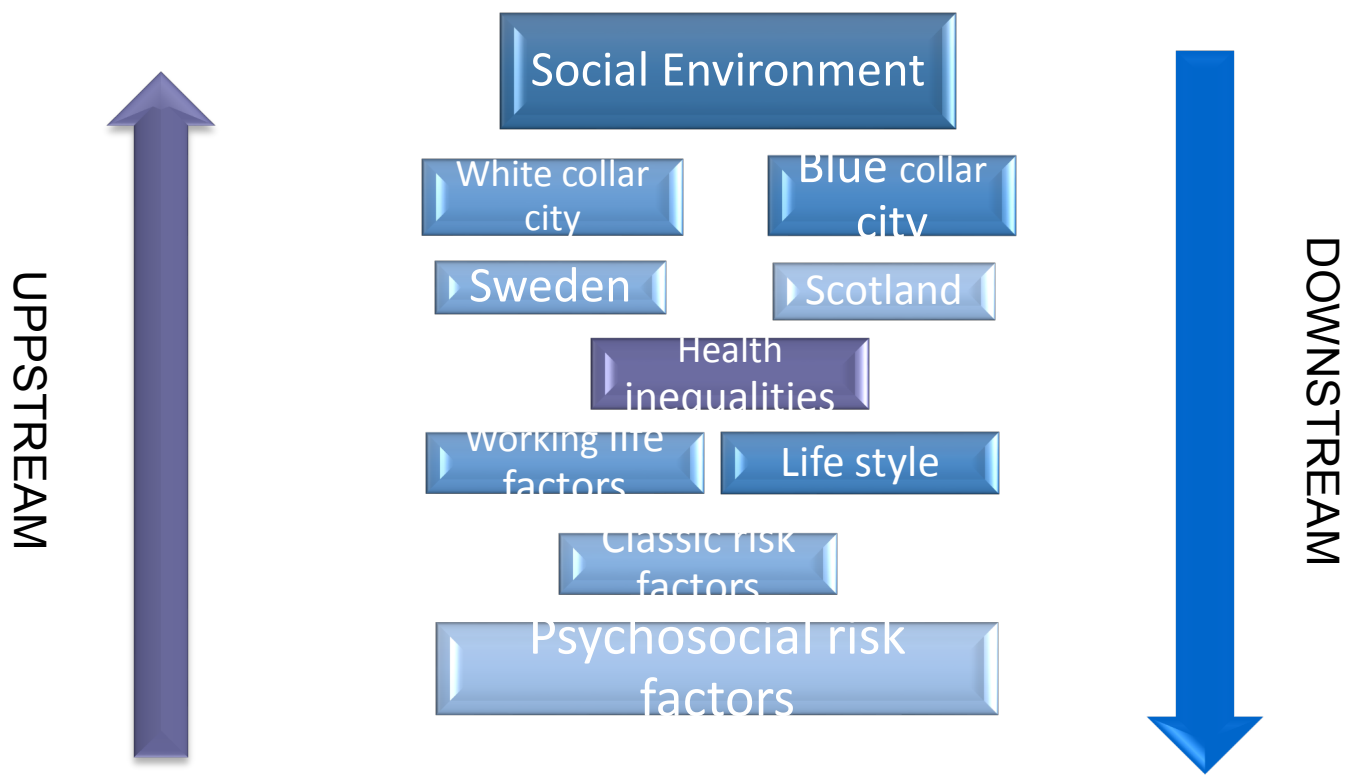

Figure 2. Model of upstream and downstream perspectives for cardiovascular diseases for middle-aged women in this thesis: 


\section{AIMS OF THIS THESIS}

\section{The overall aim:}

In this thesis, the underlying objectives were to increase the knowledge about factors in the social environment or individual circumstances that can explain why women of working age suffer from cardiovascular disease. Furthermore, the aim was to analyze cardiovascular risks and cardiovascular disease occurrence among middle-aged women in different social environments.

\section{The specific aims:}

Paper I: To compare the occurrence of the most frequent cardiovascular diseases and cardiovascular mortality in two close cities, the Twin cities.

Paper II: To explore how life had been for middle-aged women before they suffered a myocardial infarction (MI).

Paper III: To examine if the personality trait "being a Good Girl" is related to risk factors for CVD and CVD in middle-aged women.

Paper IV: To make a comparison between Scotland and Sweden regarding cardiovascular risks, lifestyle and cardiovascular disease in middle-aged women. 


\section{MATERIAL AND METHODS}

Table 1. Overview of the papers in the thesis. Paper I-IV are based on populations from the Twin cities, in Paper IV also compared with Scottish population derived from the Scottish Health Survey.

\begin{tabular}{|c|c|c|c|c|}
\hline Paper & I & II & III & IV \\
\hline Design & Register study & Qualitative study & $\begin{array}{l}\text { Cross-sectional } \\
\text { study }\end{array}$ & $\begin{array}{l}\text { Comparative Cross- } \\
\text { sectional study }\end{array}$ \\
\hline Participations & $\begin{array}{l}\text { Twin Cities, } \\
\text { Total population } \\
\mathrm{N}=285000 \text { inhabit- } \\
\text { ants }\end{array}$ & $\begin{array}{l}\text { Twin cities, } \mathrm{N}=16 \\
\text { women } 30-65 \\
\text { years, } 8 \text { women } \\
\text { from each city }\end{array}$ & $\begin{array}{l}\text { Twin Cities, } \\
\text { the QWIN-study } \\
\text { women } 40-65 \text { years } \\
N=741\end{array}$ & $\begin{array}{l}\text { Scottish Health Survey } \\
\mathrm{N}=6250 \\
\text { The QWIN-study } \\
\mathrm{N}=741 \\
\text { Women } 40-65 \text { years }\end{array}$ \\
\hline Outcomes & $\begin{array}{l}\text { CVD-morbidity and } \\
\text { mortality }\end{array}$ & $\begin{array}{l}\text { How life has } \\
\text { been for middle- } \\
\text { aged women that } \\
\text { had suffered a } \\
\text { Myocardial In- } \\
\text { farction }\end{array}$ & $\begin{array}{l}\text { Comparison of } \\
\text { high/low level of the } \\
\text { personal trait "Good } \\
\text { Girl" regarding psy- } \\
\text { chosocial and clas- } \\
\text { sical risk factors } \\
\text { and CVD morbidity }\end{array}$ & $\begin{array}{l}\text { Comparison between } \\
\text { women in Scotland } \\
\text { and Sweden regarding } \\
\text { life style, psychological } \\
\text { distress, classical risk } \\
\text { factors for CVD and in- } \\
\text { cidence of CVD }\end{array}$ \\
\hline $\begin{array}{l}\text { Data collection } \\
\text { methods }\end{array}$ & $\begin{array}{l}\text { Computerized pop- } \\
\text { ulation- based ad- } \\
\text { ministrative Health } \\
\text { Care Register } \\
\text { (HCR) }\end{array}$ & $\begin{array}{l}\text { Qualitative inter- } \\
\text { views from an in- } \\
\text { terview guide }\end{array}$ & $\begin{array}{l}\text { Questionnaire } \\
\text { survey }\end{array}$ & $\begin{array}{l}\text { Questionnaire survey } \\
\text { (Sweden) } \\
\text { Questionnaire, with an } \\
\text { interviewer (Scotland) }\end{array}$ \\
\hline Data analysis & $\begin{array}{l}\text { Epidemiological } \\
\text { anaysis } \\
\text { Relative Risks (RR) } \\
95 \% \text { confidence in- } \\
\text { terval }\end{array}$ & $\begin{array}{l}\text { Qualitative analy- } \\
\text { sis } \\
\text { Latent content } \\
\text { analysis }\end{array}$ & $\begin{array}{l}\text { Epidemiological } \\
\text { analysis } \\
\text { Chi-Square, Inde- } \\
\text { pendent T-tests } \\
\text { Adjusted for educa- } \\
\text { tional level and for } \\
\text { Care need index re- } \\
\text { lated to residential } \\
\text { by multiple regres- } \\
\text { sion analysis }\end{array}$ & $\begin{array}{l}\text { Epidemiological analy- } \\
\text { sis } \\
\text { Chi-Square, Independ- } \\
\text { ent T-test } \\
\text { Odds Ratio (OR) 95\% } \\
\text { confidence interval } \\
\text { Adjusted for age and } \\
\text { education by multiple } \\
\text { regression analysis }\end{array}$ \\
\hline
\end{tabular}




\section{Samples}

\section{The Twin cities}

The Swedish sample in study I, II, III and IV were derived from the urban population in two major cities in a region in the south-east of Sweden. The two cities, a blue-collar city and a white-collar city, are located only 40 kilometers apart in the same county in the south-east of Sweden. The same county council is responsible for all public-funded health care in the two cities and served by the same health care organization. In this region, the private health care sector is only a marginal phenomenon. The inhabitants have almost the same age distribution Today, and there are around 135 ooo-150 ooo inhabitants in each city.

the cities are fairly alike but their social history differs. Based on their history, we therefore generalize the urban identity of the cities. The term white-collar is generally used to refer to work as a civil servant. The term blue-collar refers to manual labor work. We used these terms to describe the two different social environments and geographical areas. In the 17th century, the blue-collar twin city, received its rights to foreign trade and an international port. This was the beginning of a development that made the blue collar city a center for textile industry, "The Manchester of Sweden". Many women were employed in these monotonous and badly paid jobs. Over time, the textile industry became more mechanized, and in the blue-collar city the number of unskilled workers increased. The blue collar city has become a university city in the last decade, and it is only in recent decades that non-manual occupations have become dominant. At the same time, the white-collar twin city was a regional and agricultural center dominated by a quiet life of pupils from the cathedral school. While the industrial revolution went on in the blue-collar city, the white-collar city remained a rural market town, managed by both the church and the state. There has also been a significant military presence for a long time, with several regiments stationed there. After World War II, the white-collar city grew in terms of population and became industrialized, mainly due to the aviation industry expansion. Today, the university and the high technology companies dominate the white collar city.

These evident disparities have been somewhat reduced throughout recent decades, but the cities may well be considered as typical white collar and blue collar communities. However, there are some evident differences in the populations (Faresjö et al 2010). The inhabitants of the blue collar city are generally less educated, are more often smokers, exercise less, are more overweight, have more periods of sick leave, have shorter life expectancy and a higher frequency of cardiovascular disease, gastrointestinal disorders, but also mental illness, musculoskeletal disease, and rheumatism, etc. These differences seem to have remained stable over the years (Wennerholm et al 2011, Grodzinsky et al 2012). 


\section{The QWIN-Study:}

The QWIN-study dataset was used for paper III and paper IV. The respondents were enrolled from two cities, the Twin cities. An already established partnership with eight health care centers, four in each city formed the basis for the data collection. The private health care sector is only a marginal phenomenon in the region. From an urban population attached to eight health care centers in these two cities, the Twin cities, covering a population of almost 80.000 inhabitants. Every health care center have their own patient-list. The basis for our study population derived from all the patient-lists at each health care center. The final sample was randomly selected from the urban population registered at eight health care centers, four in each city that were matched, in the Twin cities. The female inhabitants aged 40-65 who were enlisted were then invited to participate in the study. This resulted in a total of $\mathrm{N}=1.282, \mathrm{n}=638$ women in the white collar city and $\mathrm{n}=644$ women in the blue-collar city. The sample size was weighted proportionally to the population size in each of the eight health care centers. A total of $\mathrm{N}=1,282$ women were invited to participate in the study, and of these $\mathrm{n}=741 \mathrm{re}-$ sponded, giving a response rate of $58 \%$.

A power calculation showed that to ensure a $25 \%$ difference between the white collar and the blue collar groups, with a p-value less than 0.05 and with a power of at least $80 \%$, a sample of at least 300 women was required.

\section{Questionnaire}

Based on the Swedish Health Survey Questionnaire (National Public Health questionnaire, 2011), and selected parts of the Scottish Health Survey Questionnaire (User Guide, 2011), a new questionnaire was developed. The core focus of the questionnaire concentrated on psychosocial and classic risk factors for CVD, such as educational level, age, residential area, height, weight, waist circumference, general health, mental health, medication, health care contacts, lifestyle, physical activity, eating habits, smoking and alcohol consumption, economic conditions, work and employment, security and social relations. The General Health Questionnaire (GHQ 12), a standardized way of calculating the answers into a score from 0-12 points and o-36 points, was included in the questionnaire. A higher degree of psychological distress is indicated by a higher score (Goldberg et al, 1997). Face validity in the questionnaire was assessed by asking ten women to respond to the questionnaire. Some minor revisions were then made to improve clarity.

The respondents was invited to respond to a postal survey, including an information letter about the study and a postal questionnaire. The respondents were given three alternatives to respond: a postal questionnaire, an online questionnaire, or a telephone interview. The questionnaire was sent out simultaneously with the launch of the online version. Two reminders were sent out with a 2 - 3week interval. After two reminders, $\mathrm{n}=692 \mathrm{had}$ answered the postal questionnaire, whereas 72 answered the online questionnaire. The study started February $2 \mathrm{O}^{\text {th }}, 2015$ and was closed on May $1^{\text {st }}, 2015$. No one wished to be interviewed by telephone. However, 23 respondents were excluded due to incomplete answers in the questionnaire, which gave a final number of 741 respondents (58\%). 


\section{The Health Care Register (HCR):}

An administrative Health Care Register (HCR) was the basis for all analyses in paper I, II, III and IV. In the Scandinavia countries there is a long tradition of documenting diseases in registers. Based on birth date and gender, Swedish inhabitants are assigned a unique personal code.

By law, the county councils are required to report inpatient data to the Swedish Hospital Discharge register on an annual basis. National registration of outpatient data has not yet been implemented (Wirhen et al 2007). In one region in the south-east of Sweden, patient data from primary health care (PHC), outpatient hospital care, and hospital care have been recorded for some years in a shared computerized population-based administrative Health Care Register (HCR). Data from this register have high validity and accuracy and are therefore appropriate for epidemiological studies (ibid).

\section{The Scottish Health Survey - SHeS:}

Initially, the Scottish data were based on the Scottish Health Survey (SHS) that was designed to provide data at a national level about the population living in Scotland in private households. It was not designed to deliver subnational regional data on an annual basis. Since 2008, the survey has been continuous and takes place every year, with a core set of questions repeated every year so that multiple waves in four-year blocks can be combined to create larger samples for analysis. In this study, we used the combined dataset for 2008-2011, following the user guide for 2011 (Userguide 2011).

The sample for the 2011 survey was drawn from the Postcode Address File (PAF). An initial sample of 10431 was selected. The addresses were comprised of three sample types, where $\mathrm{N}=7971$ formed the main sample. All private households in the sample were eligible for inclusion in the survey (up to a maximum of three households per address). Data collection involved an interview, and if applicable, adults in the main sample also had a follow-up visit from a specially trained nurse. In the Scottish Health Survey Questionnaire (SHeS), each survey in the series consists of a set of core questions and measurements (for example, anthropometric and, if applicable, blood pressure measurements and analysis of blood and saliva samples), plus modules of questions on specific health conditions (self-reported), general health, and psychosocial distress (GHQ 12), as well as risk factors such as physical activity, fruit and vegetable consumption, smoking, drinking, employment status, and educational background.

As with the earlier surveys in the series, the principal focus of the 2011 survey was cardiovascular diseases (CVD) and related risk factors. The main components measured in the SHeS are ischemic heart disease (IHD) and stroke. In the Scottish survey, people were simply asked if their reported diseases were doctor-diagnosed (Userguide, 2011).

\section{Paper I}

\section{Study sample}

The morbidity data presented were derived from a computerized populationbased administrative health care register (HCR) in a region in the south-east of 
Sweden; more precisely two major cities, the white collar city (number of inhabitants 144690 (2009), and the blue collar city (total number of inhabitants 129254 (2009). The first diagnosed cases were identified during the six-year study period (2002-2007).

Table 2. Indicators of the social environment in the white collar and blue collar twin city.

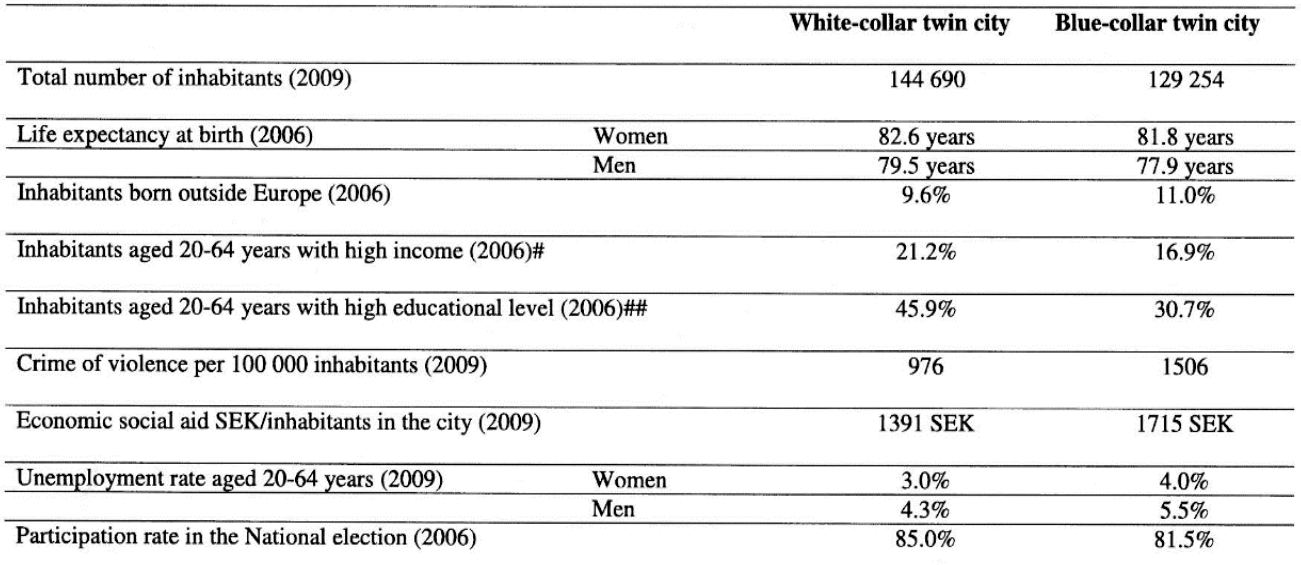

Note: Data for 2006 from Official Statistics, the Swedish Institute of Public Health and Statistics, Sweden.

\#High income refers to the $20 \%$ of the inhabitants nationally with the highest income. \#\# High education refers to 12 or more years of education.

Swedish national data on mortality for ischemic heart diseases (mainly heart infarction) in the largest Swedish cities (all cities with over or around 100 ooo inhabitants) were also included. It represents early mortality in the population from the age of 15 and above in each city between 2002 and 2006 and are age standardized against the national Swedish population (Swedish National Institute of Public Health, 2008).

The historical mortality data of cardiovascular diseases in the twin cities is based on national mortality statistics from The Statistics in Sweden.

Swedish national data on mortality for ischemic heart diseases (mainly heart infarction) in the largest Swedish cities (all cities with around 100 ooo inhabitants or more) was also included. It represents early mortality in the population from the age of 15 and above in each city between 2002 and 2006, and are age standardized against the national Swedish population (Swedish National Institute of Public Health, 2008). The historical mortality data of cardiovascular diseases in the twin cities is based on national mortality statistics from The Statistics in Sweden.

\section{Diagnoses}

The International Classification of Diseases (ICD 10-code) for the CHD disorders presented in Paper I was: E78 (high cholesterol), I10 (hypertension), I20.9 
(angina pectoris), I21 (myocardial infarction), I25 (ischemic heart disease), I50 (cardiac insufficiency), I61.9 (cerebral haemorrhage), I63 (stroke). Physicians in hospitals as well as in primary care assigned these diagnostic codes.

\section{Paper II}

\section{Study sample}

The participants in this study were selected from a regional administrative health care register (HCR) in a region in the south-east of Sweden. The study population consisted of all women $\mathrm{N}=59,217$ in the age group 30-64 years, living in the two major cities in the county, the Twin cities,.

During the two-year study period (2009-2010), a total $n=46$ women from this study population had suffered a myocardial infarction (ICD-I21). Of these, $n=28$ women lived in the blue collar city and $n=19$ women in the white collar city. This resulted in an annual incidence rate of 4.9 per 10,000 women in the blue collar city and 3.1 per 10,000 women in the white collar city; a risk ratio difference of 1.51 (95\% CI 0.84 - 2.72). A strategic selection was done within the total group of $\mathrm{n}=46$ women with MI (ICD-I21), with the intention to obtain a social variety in type of residential area, age, ethnicity, and living in the blue collar or the white collar city. A total of $n=16$ women were selected as informants in the study, $n=8$ women from each city. The mean age of the women at the time of their MI was 54 years, (ranging from 41 - 64 years). The educational level for the women was $n=3$ elementary school, $n=9$ above elementary school and $n=4$ university education. At the time of the MI, the women's occupations were $n=8$ employed, $n=5$ unemployed, and $n=3$ early retirement.

\section{Qualitative interviews}

Prior to the data collection, a pilot interview with one woman was conducted to test the validity of the interview guide. An information letter regarding the study was sent to the convenience sample informants, which was followed by a phone call one week later. All contacted women agreed to participate. The majority of the interviews took place at the informants' homes, except for two made by telephone and one at the university according to the women's preferences. The interviews were conducted from March 2011 to March 2012 by the two researchers, who alternated between the role as leader or observer. The role as a leader was mainly to push the conversation forward, ask questions, etc., while the observer's role was to make comments and document impressions during the conversation. Both these interviewers are trained in interview techniques and have extensive experience of the interview situation. In this qualitative content study, an open inductive approach described by Graneheim \& Lundman was applied (Graneheim \& Lundman, 2004). An open interview guide with broad themes that covered the women's life stories including experiences of their childhood, relations, education, occupation and their own health and well-being, was used.

Examples of questions derived from the open interview guide are "Could you tell us about your childhood" or "How is your daily life now?" The interviews lasted $60-90$ minutes and were recorded and then transcribed verbatim by the two researchers. 


\section{Paper III}

Study sample

This study had a cross-sectional design and was mainly based on a survey distributed to middle-aged women (aged 40-65 years). Additional data on diagnoses, i.e., doctor- set ICD-10 diagnoses (International Classification of Diagnosis) were retrieved from a regional health care register in a county in the south-east of Sweden. The diagnosis followed the International Classification of Diseases (ICD 10code) for the CVD disorder. The diagnosis was accumulated over five years, i.e., it only occurred once in our database

\section{Diagnoses from Health Care Register (HCR)}

\section{Cardiovascular Diagnoses:}

I20.0 Instabile angina pectoris

I20.1 Angina pectoris with documented spasm

I20.8 Other forms of angina pectoris

I20.9 Angina pectoris, unspecified

I21 ST elevation (STEMI) and non-ST elevation

(NSTEMI) myocardial infarction

I25 Chronic ischemic heart disease

G45 Transient cerebral ischemic attacks and related syndromes

Ro7 Pain in throat and chest

I50 Heart Failure

Ro6 Abnormalities of breathing

\section{Cerebral:}

I61 Nontraumatic intracerebral hemorrhage

I63 Cerebral infarction

I64 Cerebrovascular insult

I67-P Other cerebrovascular diseases

I69.1 Sequelae of nontraumatic intracerebral hemorrhage

I69.2 Sequelae of other nontraumatic intracranial hemorrhage

I69.3 Sequelae of cerebral infarction

I69.4 Sequelae of acute cerebrovascular disease, not specified as haemorrhage or infarction

I69.8 Sequelae of other cerebrovascular diseases

I69 Sequelae of cerebrovascular disease

Figure 3. Diagnoses from HCR as a complement for the self-reported data in the QWIN-study. 
The sample in this study was enrolled from the urban population registered at eight health care centers, four in each city that we matched, in the Twin cities. The private health care sector only plays a marginal role in both cities. Female inhabitants aged 40-65 years were randomly selected proportionally from each health care center, and were then invited to participate in the study. In total, $\mathrm{N}=1.282$ women, $\mathrm{n}=638$ women in the white- collar city and $\mathrm{n}=644$ women in the blue collar city.

\section{Questionnaries}

A questionnaire was developed using questions from the Swedish Health Survey Questionnaire (National Public Health questionnaire, 2011), and selected parts of the Scottish Health Survey Questionnaire (Userguide, 2011). The main topic of the questionnaire focused on psychosocial and classic risk factors for CVD, such as educational level, age, residential area, height, weight, waist circumference, general health, mental health, medication, health care contacts, lifestyle, physical activity, eating habits, smoking and alcohol consumption, economic conditions, work and employment, security and social relations.

This group of women was invited to respond to a postal survey, including an information letter about the study and a postal questionnaire. The respondents were given three alternatives to respond: a postal questionnaire, an online questionnaire, or a telephone interview. The questionnaire was sent out simultaneously to the launch of the online version. Two reminders were sent out with a 2 3 -week interval. After two reminders, $n=692$ had answered the postal questionnaire, whereas 72 answered the online questionnaire. No one wished to be interviewed by telephone. The study was opened February 20, 2015 and closed May 1, 2015. However, 23 respondents were excluded due to incomplete answers in the questionnaire, which gave a final number of 741 respondents (58\%).

\section{The Swedish National Public Health Questionnaire}

Every year since 2004, the national public health survey has been run. The questionnaire from 2016 covered 60 questions on a total of 13 pages. It was shorter than in previous years as it used to include about 90 questions on 18 pages.

The national public health survey includes questions on physical and mental health, drug consumption, health care contacts, dental health, lifestyle, economic conditions, work and occupation, work environment, safety and social relationships (National Institute of Public Health Sweden, 2009).

In conclusion, the topics in the national public health survey used in our QWINquestionnaire were psychosocial and classic risk factors for CVD, such as educational level, general health, mental health, medication, health care contacts, lifestyle, physical activity, eating habits, smoking and alcohol consumption, economic conditions, work and employment, security and social relations.

\section{General Health Questionnaire (GHQ 12)}

As a screening device, The General Health Questionnaire (GHQ) can be used for identifying minor psychiatric disorders within a community or non-psychiatric clinical settings, such as primary care or general medical outpatient units, and also in the general population. 
It is appropriate for all ages from adolescence and up, but it is not suitable for children. It is used to assess the respondent's current state and to distinguish whether it differs from his or her usual state. The General Health Questionnaire is therefore sensitive to short-term psychiatric disorders, but not long-term conditions. The self-administered questionnaire concentrates on two major areas: The presence of new and distressing phenomena and the inability to carry out normal functions. GHQ 12 was included in the survey, and a standardized way of calculating the answers into a score from 0-36 points was used. A higher score indicated a higher degree of psychological distress (Goldberg \& Williams, 1988).

\section{Index for "Being a Good Girl":}

The index"being a Good Girl" (GG) was created to measure the personality traits of "being a Good Girl". This index was based on three questions referring to the experience of the interview study (Wennerholm, 2014): "Do you place high demands on yourself”?, "Do you have difficulties prioritizing your own needs?”, and "Do you have difficulties saying no in contacts with other people, or when someone asks for help?" All items had three response categories ranging from 1 to 3; "Yes, definitely" = 3 points, "Yes, partly 2 points", and "No, 1 point", maximum score 9 points. The questions were initially formulated based on our previous qualitative study of middle-aged women who had suffered myocardial infarction (Wennerholm et al, 2014).

To justify the index (i.e., to evaluate if the items would form a uni-dimensional measure), a factor analysis based on a principal component extraction method was conducted. Based on the Kaiser-Meyer-Olkin test (0.624) and Bartlett's test of sphericity $\left(\chi^{2}(3)=274.1, \mathrm{p}<0.001\right)$, a factor analysis was considered appropriate. The Kaiser-Guttman rule (i.e., eigenvalues greater than 1.0) was used to decide the number of factors to extract. The factor analysis ended up in a one factor solution that explained $57.5 \%$ of the total variance. The factor loadings ranged between 0.73 and 0.82 , and were therefore considered to be significant according to the sample size (Pett et al, 2003). Women with a score 0-7 constituted the low level Good Girl group, while women with a score of 8-9 points were classified as the high level Good Girl group. By using this "being a Good Girl Index", a total of $\mathrm{n}=112$ women in this study were classified as "high level Good Girl", whereas $\mathrm{n}=629$ women were classified as "low level Good Girl".

\section{Care Need Index:}

For classifying the residential area of the participating women, the Care Need Index (CNI) was applied. This index was initially developed to measure social deprivation and the impact of social factors on the workload in Swedish primary health care.

It is based on eight sociodemographic factors; elderly living alone, high mobility, foreign born inhabitants from non-western countries, single parent families, children under five years, unemployment rate, people with low education status, and crowded households. Each geographical area that belonged to a certain health care center had a CNI, which was divided into low CNI (0.50.99), middle (1-1.49), and high CNI (1.5-2) (Sundqvist et al, 2003). 


\section{Paper IV}

\section{Study sample}

Sweden

The Swedish data collection was mainly based on a postal survey to middle-aged women (aged 40-65 years), and the QWIN-study, the same study as in paper III. Besides this data collection, some additional data on cardiovascular diagnoses were merged from a regional health care register, based on health care visits and doctors' diagnosis (as in paper III).

\section{Scotland}

The Scottish data were based on the Scottish Health Survey (SHeS), which was designed to provide data at a national level about the population living in private households in Scotland. The Swedish sample was derived only from urban areas. For this study, we excluded Scottish women living in the regions of Highlands, Orkney, Shetland and Western Isles, as these are rural and remote areas. In the Scottish sample, 6,250 women 40-65 years were included, upon which the analyses presented here are based.

\section{QWIN/SHeS combined dataset}

The QWIN/SHeS combined dataset is built on two other datasets, QWIN and SHeS, which in turn build on two different surveys described previously.

The two datasets, QWIN and SHeS, were examined for comparable variables and these data were merged into a new dataset entitled QWIN/SHeS.

A group of qualified researchers from each site evaluated the questions and defined the variables eligible for valid comparisons between the two countries. The variables included in the final Swedish - Scottish merged database were: sociodemographic characteristics, anthropometrics, lifestyle, classic risk factors for CVD, and diagnoses for CVD, general health and psychosocial distress (GHQquestionnaire 12 items). The variable "CHD" includes the diagnoses angina pectoris, unstable angina pectoris, ischemic heart disease, and myocardial infarction merged together.

The variable "CVD" includes the diagnoses heart failure, angina pectoris, unstable angina pectoris, stroke, ischemic heart disease, and myocardial infarction merged together.

\section{Ethical considerations}

To access medical records for paper I, an approval from the ethics committee was needed. The Regional Ethical Review Board in Linköping, Sweden approved the study (Dnr. 2009/26-31).

In paper II, an interview study, the same medical records and dataset were used as in paper I, with same main ethical approval. All participants gave their written and informed consent to participate in the study. A supplementary application was made for the interview study, i.e., The Regional Ethical Review Board in Linköping, Sweden (Dnr. 2010/172-32). 
For Paper III, a questionnaire was sent to middle-aged women, 40-65 years, in the Twin cities,. This was approved by The Regional Ethical Review Board in Linköping, Sweden (Dnr.2014/240-32). To access ICD-diagnoses in the administrative health care register (HCR), in order to confirm the self-reported data and strengthen the study, an additional application was made and approved by The Regional Ethical Review Board in Linköping, Sweden (Dnr.2015/240-32).

For Paper IV, the same data was used as in Paper III regarding the Swedish data, so no further ethical approval was required. For the Scottish data, a large national Scottish Health Survey applies. Ethical approval for the Scottish surveys (20082011) was granted by the Multi-Centre Research Ethics Committee for Wales (REC reference numbers: 07/MREo9/55 and 08/MRE09/62).

\section{Data analysis}

\section{Qualitative content analysis}

Qualitative content analysis and latent content was chosen as analysis method of the qualitative interviews (Graneheim \& Lundman, 2004). In this study, we followed the recommendations and criteria for reporting qualitative research included in the COREQ checklist (Tong et al, 2007). The data were analyzed in the following steps:

1) Audiotapes of the 16 women were listened to and thereafter transcribed, read and re-read by the authors.

2) The text was divided into five content areas; working life, childhood, present life circumstances, serious life events, self-image and view of life, and experiences/perceptions of their myocardial infarction. Each was analyzed separately.

3) Meaning units (words, sentences or paragraphs) containing aspects related to each other through content and context were identified.

4) The meaning units were thereafter condensed and labeled with codes. This text was shortened while still preserving the core.

5) These codes were compared based on similarities and differences and sorted into categories based on similarities.

6) The analysis process involved movements back and forth between the whole text, the codes and the categories for each theme. An interpretation of the underlying meaning that permeated the categories within the content area was formulated into five themes. Reliability and validity was ensured by verifying and interpreting the data in all stages of the analysis according to standard proceeds for qualitative studies (Graneheim \& Lundman, 2004). When the final interpretation of the data was done, all four researchers gathered and discussed the issues to reach a consensus.

\section{Statistical analysis}

For Paper I, the International Classification of Diseases (ICD 10-code) was derived from the health care register (HCR). The CHD disorders presented in this study were: E78 (high cholesterol), I10 (hypertension), I20.9 (angina pectoris), I21 (myocardial infarction), I25 (ischemic heart disease), I50 (cardiac insufficiency), I61.9 (cerebral hemorrhage), and I63 (stroke). Physicians in hospitals as well as in primary care assigned these diagnostic codes. The morbidity data presented are cumulative incidence rates. 
The numerator for the cumulative incidence rates was the number of the first diagnosed cases identified during the study period (2002-2007). The denominator was the number of inhabitants calculated as the mean number in each age group of the population during the six-year study period. The cumulative incidence rates are presented as numbers per 1,00o inhabitants. Swedish national data on mortality for ischemic heart diseases (mainly myocardial infarction) in the largest Swedish cities (all cities with around 100 ooo inhabitants or more) were also included. They represent early mortality in the population from the age of 15 and above in each city between 2002 and 2006, and are age standardized against the national Swedish population (Swedish National Institute of Public Health, 20042008). The historical mortality data of cardiovascular diseases in the Twin cities is based on national mortality statistics from The Statistics in Sweden.

Data were stored in a shared database and statistically analyzed using SPSS 17.0 (SPSS Inc., Chicago, IL, USA). Risk ratios (RR) and 95\% confidence intervals (CI) were calculated based on crude data with the white collar city as the reference group. Independent sample T-test was used for continuous variables when analyzing anthropometrics in Paper III and IV, and to identify differences between the Swedish and Scottish subgroups, social characteristics and anthropometric data. The Pearson chi square test was used for categorical variables in both Paper III and IV.

Mean and standard deviation was used in Paper III for continuous variables comparing high level Good Girl and low level Good Girl, and in Paper IV for continuous variables comparing the Scottish middle-aged women and Swedish middleaged women.

In Paper III, cross-tabulation with Person chi-square test was used to examine differences in the categorical variables in the high level vs. low level Good Girl group. The same applies to Paper IV regarding the examination of differences between Scottish middle-aged women and Swedish middle-aged women. In the Chi square test and crosstabs, variables with more than two possible answers were dichotomized in both paper III and IV. In both paper III and IV, the variable CHD includes the diagnoses angina pectoris, unstable angina pectoris, ischemic heart disease, and myocardial infarction. The variable CVD includes the diagnoses heart failure, angina pectoris, unstable angina pectoris, stroke, ischemic heart disease and myocardial infarction.

In paper III, the high vs. low level Good Girl groups the variables for lifestyle, risk factors for CVD, medication, diagnoses for CVD, depression and anxiety were analyzed using bivariate analysis. All bivariate analyses were also adjusted for educational level and for the Care Need Index related to residential area in multiple logistic regressions. In paper IV above all, prevalence odds ratios estimates (OR) were calculated for almost all outcomes with 95\% confidence intervals (CI). Current analyzed variables were sociodemographic characteristics, anthropometrics, life style, classic risk factors for CVD and diagnoses for CVD, general health and psychosocial distress (GHQ-questionnaire 12 items).

The analysis in paper IV was adjusted by using logistic regression for age and educational level. Variables with more than two categories in paper IV were divided for BMI as follows; Underweight < 18.5, Normal Weight 18.5-24.9, Overweight 25-29.9 were compared with Obese 30-50. 
For self-assessed health, good and fair were compared with bad, and for education level, high and medium education were compared with low education. Each GHQ variable was dichotomized from four answer options to two for the odds ratio estimate.

In Paper I, III and IV all data were analyzed using SPSS 23.o (SPSS Inc., Chicago, IL, USA). A p-value of $\mathrm{p}<0.05$ was considered statistically significant. 


\section{RESULTS}

\section{Overview of the results in the present thesis}

The overall aim of this thesis was to increase our knowledge of factors in the social environment and of individual factors that could explain why some women of working age are affected by cardiovascular diseases. Furthermore, the aim was to analyze cardiovascular risks and cardiovascular disease occurrence among middle-aged women in different social environments.

This thesis started with a comparison of cardiovascular morbidity and mortality in two different social environments, a blue collar and a white collar city, referred to as the Twin cities. Profound differences in cardiovascular morbidity and mortality between these cities were found, where the population in the blue collar city was most affected. These differences in cardiovascular risks also seem to be stable over time. Our initial findings inspired us to dig deeper into the issue of cardiovascular risks and middle-aged women. Who are these middle-aged women that have suffered a myocardial infarction and what their lives were like before they became ill? To shed some light on these questions, a qualitative interview study was conducted, focusing on middle-aged women who had recently suffered a myocardial infarction. The findings revealed a broad picture of social factors, life circumstances, personalities and, not least, psychosocial factors that are important to middle-aged women who have suffered an MI. The psychosocial phenomenon to strive "to be a Good Girl" was a personality trait also found, to which these women have been shaped throughout their lives.

A quantitative study of middle-aged women within the frame of the Twin cities, the QWIN-study, was next step.

This study indicated that women demonstrating a high level of the personality trait labeled "being a Good Girl" have more psychological distress, a higher incidence of diagnosed depression and self-reported anxiety, tiredness, consider themselves to be pedantic, and more commonly report chest pain without seeking medical care.

However, no increased prevalence of cardiovascular diseases was found among women in the high level Good Girl group compared to the low level Good Girl group.

To further elaborate on the importance of the relationship between social environment and cardiovascular risks, a study comparing differences between Scotland and Sweden was carried out. The population of Scotland is known to have one of the highest cardiovascular mortality rate in western Europe. This study focused on middle-aged women and cardiovascular risk factors, morbidity and lifestyle factors.

This comparative study clearly showed that Scottish middle-aged women are relative to Swedish women - particularly affected by a worse profile of CVD risks, even after adjustment for education. 


\section{Paper I}

Cardiovascular morbidity

The cumulative incidence of different cardiovascular diagnoses was calculated for younger men and women (aged 45-64 years). Significant differences were revealed in all studied diagnoses in the comparison between the Twin cities, except for high cholesterol levels.

Table 3. Cumulative incidence of cardiovascular disease and cardiovascular risk factors (according to the diagnoses in ICD-10) and RR (risk ratio) for women 4564 years (diagnosed 2002-2007) in the Twin Cities.

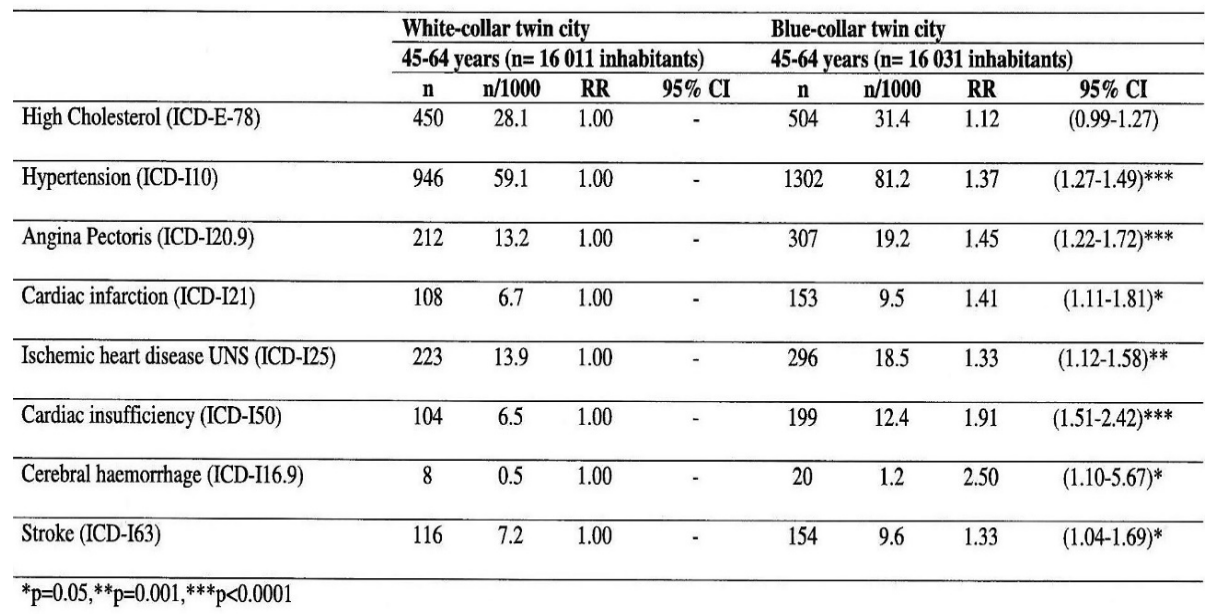


Table 4. Cumulative incidence of cardiovascular disease and cardiovascular risk factors (according to the diagnoses in ICD-10) and RR (risk ratio) for women 6579 years (diagnosed 2002-2007) in the Twin cities.

\begin{tabular}{|c|c|c|c|c|c|c|c|c|}
\hline & \multirow{2}{*}{\multicolumn{4}{|c|}{$\begin{array}{l}\text { White-collar twin city } \\
65-79 \text { years ( } n=8151 \text { inhabitants) }\end{array}$}} & \multicolumn{4}{|c|}{ Blue-collar twin city } \\
\hline & $65-79$ & & & ants) & $65.79 y$ & rs $(n=80$ & inhabi & \\
\hline & $\mathrm{n}$ & $\mathrm{n} / \mathbf{1 0 0 0}$ & $\mathbf{R R}$ & $95 \%$ CI & $\mathrm{n}$ & $\mathbf{n} / \mathbf{1 0 0 0}$ & RR & $95 \%$ CI \\
\hline High Cholesterol (ICD-E-78) & 608 & 74.6 & 1.00 & - & 526 & 65.6 & 0.88 & $(0.79-0.99)^{*}$ \\
\hline Hypertension (ICD-I10) & 1644 & 201.7 & 1.00 & - & 2026 & 252.8 & 1.25 & $(1.18-1.33)^{* * *}$ \\
\hline Angina Pectoris (ICD-I20.9) & 548 & 67.2 & 1.00 & - & 616 & 76.9 & 1.14 & $(1.02-1.28)^{*}$ \\
\hline Cardiac infarction (ICD-I21) & 392 & 48.1 & 1.00 & - & 391 & 48.8 & 1.01 & $(0.89-1.16)$ \\
\hline Ischemic heart disease UNS (ICD-I25) & 542 & 66.5 & 1.00 & - & 645 & 80.5 & 1.21 & $(1.08-1.36)^{* *}$ \\
\hline Cardiac insufficiency (ICD-I50) & 539 & 66.1 & 1.00 & - & 700 & 87.3 & 1.32 & $(1.19-1.47)^{* * *}$ \\
\hline Cerebral haemorrhage (ICD-I16.9) & 16 & 2.0 & 1.00 & - & 42 & 5.2 & 2.67 & $(1.50-4.74)^{* *}$ \\
\hline Stroke (ICD-I63) & 316 & 38.8 & 1.00 & - & 348 & 43.4 & 1.12 & $(0.97-1.30)$ \\
\hline
\end{tabular}

In the blue collar city population, the relative rates were higher for both sexes. The cumulative incidence of different cardiovascular diagnoses was also calculated for elderly men and women (aged 65-79 years). Even in these age-groups, significantly higher relative rates of the studied cardiovascular diagnosis were shown among the elderly in the blue collar city compared to the white collar city. One exception was the diagnosis high cholesterol levels, which was significantly more common among both males and females in the white collar city. Regarding myocardial infarction and stroke, no difference in occurrence in elderly women was found between the cities. 


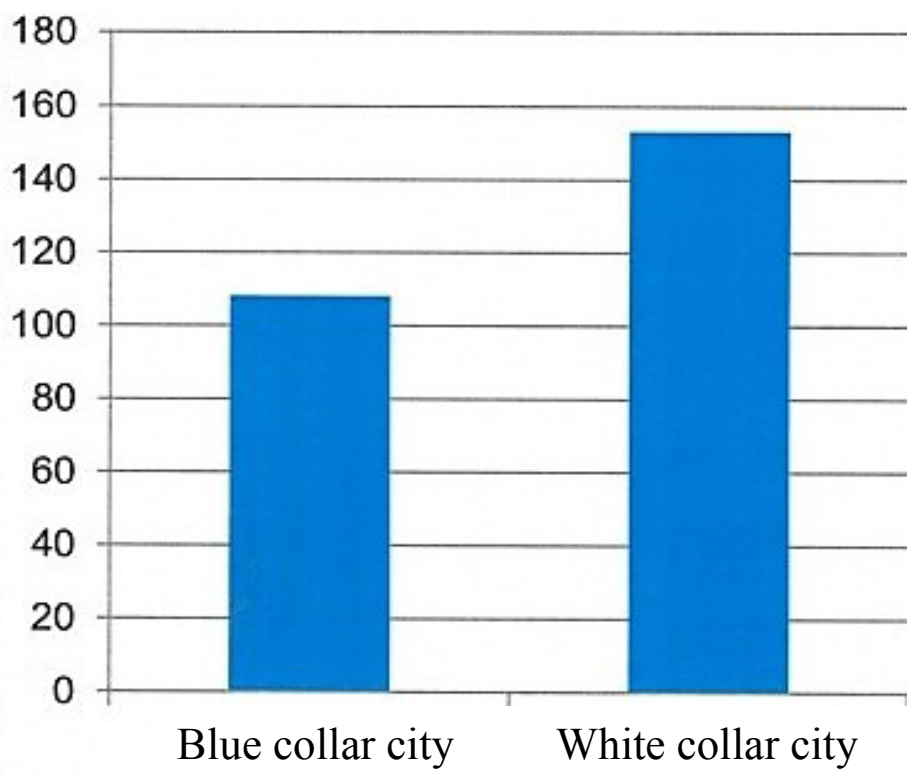

Figure 4. Incidence of myocardial infarction for middle-aged women year 20022007 in white collar city and blue collar city, the Twin cities. 


\section{Cardiovascular mortality}

Swedish national data (2002-2006) on mortality in association with ischemic heart disease from all Swedish cities with around 100 ooo inhabitants or more were chosen for this comparison. Mortality rates were generally higher in males than females. The blue collar city had the highest mortality rates in association with ischemic heart diseases in both males and females, related to all other comparable Swedish cities of the same size. The white collar city had lower mortality rates than the national mean in this respect in both females and males.

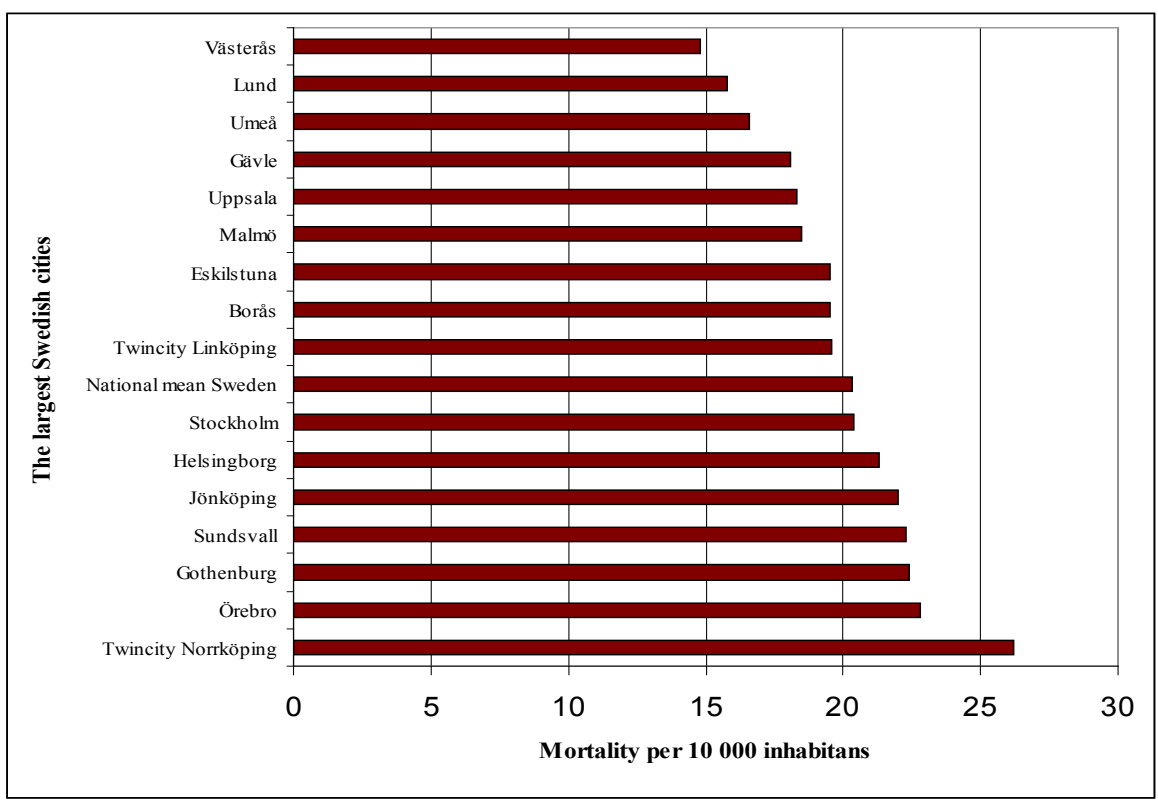

Figure 5. Mortality in ischemic heart diseases (all ages over 15, age-adjusted) yearly per 10 ooo inhabitants for females in the largest Swedish cities (around and above 100 ooo inhabitants) 2002-2006. Data from National Board of Health and Welfare, Sweden 2010. 


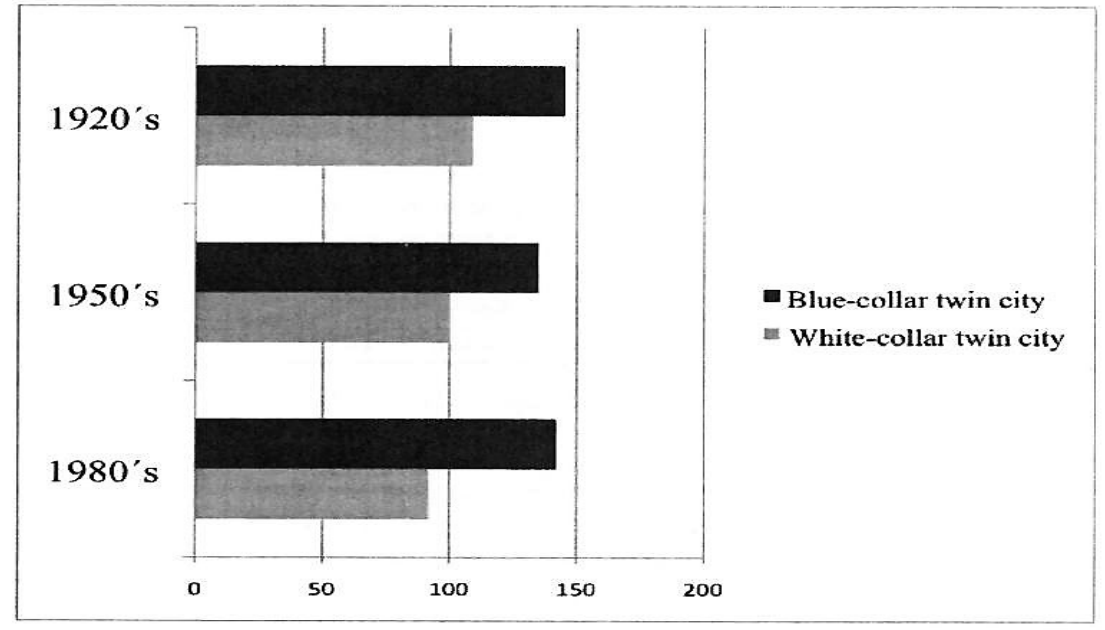

Figure 6. Present historical data of cardiovascular mortality for the Twin cities. A higher rate of coronary heart mortality is evident in the population of the blue collar city from the 1920's until recent decades compared with the white collar city. 


\section{Paper II}

Table 5. Themes and categories concerning what life had been like for middleaged women before they suffered a myocardial infarction, and some characteristics of their personalities $(\mathrm{N}=16)$.

\begin{tabular}{|l|}
\hline Themes and categories \\
\hline A:Serious life events \\
A1:Childhood life events \\
A2:Adult life events \\
\hline B:Negative affectivity \\
B1:Cynicism \\
B2:Hostility \\
\hline C:Loneliness \\
C1:Lack of reliance \\
C2:Betrayal \\
\hline E:Being a Good Girl \\
E1:Conscientiousness \\
E2:Self-sacrifice \\
\hline F:Lack of control \\
F1:Victims of circumstances \\
F2:Failure \\
\hline
\end{tabular}

\section{A: Serious life events}

The women who were interviewed had all experienced serious life events in their childhood and/or adulthood. Traumatic life events are part of most people's lives. However, these women often had a history of extreme and repeated trauma.

\section{A1: Childhood life events}

The women described $t$ being sexually abused by close relatives and that the adults pretended not to see what happened. They expressed that they were abused as a child or lived in dysfunctional families and violent environments. Furthermore, they talked about growing up with parents with alcohol problems and/or mental health problems, who were not able to take their responsibility. Informants described their experiences as being a refugee of war and that they had to take an adult responsibility early in life. "We escaped the holocaust (...), it's been very, very tough." [D]

A2: Adult life events - In adult life, the informants suffered from severe diseases, were abused or experienced serious betrayals. An abusive husband left a woman while heavily pregnant; another woman discovered as an adult that she had another biological father than her siblings. Furthermore, the women had children who suffered from severe mental and/or physical illness, or had conflicts at work that resulted in dismissal. One woman reported that she had repeatedly tried to commit suicide. Additional examples were sexual abuse or criminality in the close family. Another example is a woman who was affected by unemployment, which in turn led to a considerable life crisis. "It really has been hard on me, I mean really, really hard, to become unemployed." [B] 


\section{B: Negative affectivity}

Common features for these women were a general negative affectivity, with negative attitudes and thoughts, hostility and cynicism.

\section{B1: Cynicism}

Some women expressed a negative attitude towards relatives, friends, co-workers and people in general. This was also reflected in the way they described other people and what they expected from them. Statements of mistrust of foster families could illustrate this; "that they only want money for taking care of children." [A]. Another expression of cynicism was self-blame, portrayed by an informant who felt that she deserves to be punished. One woman described disappointment of her husband, and insinuated that he was irresponsible; "My husband always went away (...) I even thought of putting a photo of him on the door so I could tell the children 'this is what your father looks like' so they would recognize him when he showed up." [B]

\section{B2: Hostility}

A hostile attitude demonstrates itself as always thinking the worst about people, and becoming agitated over their behaviors. The informants expressed that they blame other people for things they had done wrong. One woman said that her manager was stupid, but the woman herself probably failed to do her job. Another informant even blamed her neighbors and colleagues for giving her MI as their bad manners upset her. The informants described it as hard not to care about what others do and that things need to be done properly and thoroughly. Furthermore, one woman stated that she was aware of her hostile attitude and that it affected her in a negative way.

"I show my claws (...) and always think the worst about people." [L]

\section{C: Loneliness}

Some women expressed a lack of social support and someone to trust. They also had a tendency to keep their problems and sorrows to themselves.

\section{C1: Betrayal}

The informants described that they had been exposed to severe betrayals in their childhood or/and as adults. The women talked about parents who did not manage to take responsibility for their family. As a consequence, they were left alone without any support as young children. Furthermore, parents and adults did not care when abuse occurred. Another example was a woman who was left on her own with young children, without any support from her husband who was an alcoholic.

One woman referred to her mother who caused conflicts in the family, especially between the siblings, which affected her relationships with other people; "My mum caused conflicts between us siblings and as a result, my relationship with my sisters is still bad." [L] 


\section{C2: Lack of reliance}

The women found it difficult to share their thoughts and problems and did not trust others. For example they kept all their feelings to themselves so as not to be a bother "I never show my sadness, it goes inwards." [A].

This is particularly true of their relationships with husbands and close relatives, but they were often willing to listen to and support others. The informants described that they always had to fend for themselves and did not expect any support from anyone, but it was our impression that there are people around who want to listen and help, but the women do not allow them to; "Ive had to take a lot of responsibility, had to rely on myself." [B]

\section{E: Being a Good Girl}

The women were in most cases extremely dutiful and had high demands on themselves. It was important to them and they also wanted others to perceive them as "Good Girls". They also had a self-sacrificing behavior and always put their own needs aside.

\section{E1: Conscientiousness}

Most of the women were responsible for the home and family while also holding down a full-time job. The informants told us that they belong to that generation where women are responsible for the home and family and are expected to cope with it and enjoy it. Furthermore, the informants did not want to work less even if the doctor told them to do so for health reasons. For them, this was perceived as unthinkable. One woman had strict ideas of right and wrong and how to manage things. She became so upset with her colleagues mismanaging their jobs that she even thought this might have caused her MI; "Ive always been too well-behaved (...) shouldered responsibility and became very upset about skiving colleagues." $[\mathrm{H}]$ Another woman continued teaching her class at school, despite an ongoing MI. After the class, her colleagues found her unconscious; "They had to be allowed to take their test." [D]

\section{E2: Self-sacrifice}

A common characteristic among the interviewed women was that they had a selfsacrificing behavior and seldom prioritized their own needs; "You can't say no, you just have to do your bit." [C]. Other perceptions were that you should never go to the doctor just because you are $t$ tired. They often wanted to be a perfect wife, mum, friend and employee, and were often expected by their friends and family to help out; "My family and my parents have also put all responsibility on me because I have the strength to deal with everything...so I have never cared about myself, Ive never done that because you're expected to be able to handle everything." [D].

\section{F: Lack of control}

It appeared that most of the women did not have control of their lives and often failed in their career and relationships. Things just happened and they often did not see their potential to change or take control over conditions in life. They were "victims of circumstances". 


\section{F1: Failure}

The informants also expressed dreams and goals with their lives, but often failed to achieve them. These barriers could include having children out of wedlock when they were too young or broken marriages ending up in divorce.

The women felt that they had failed in their motherhood; they even had children in foster homes. The informants had experienced conflicts at work that resulted in dismissal. Other examples are failure to achieve educational goals or returning to work after a period of sick leave. "I've had a dream that everything would be like before and that she would go back to work. That was the goal "to be like everybody else", but then I became a disability pensioner in 2009 and then made redundant in 2010. That was tough, very hard indeed." [P]

\section{F2: Victims of circumstances}

The women did not acknowledge that they were responsible for their lives and blamed others for their misery. They also seemed to have insufficient belief in themselves to be able to influence the future. This as described by a woman who could not understand why nobody told her that her son was using drugs. Another example is a woman who just lost her job and did not seem to reflect on why or how she could have avoided it. "I constantly feel badly treated and that everybody else is in the wrong." [A] 


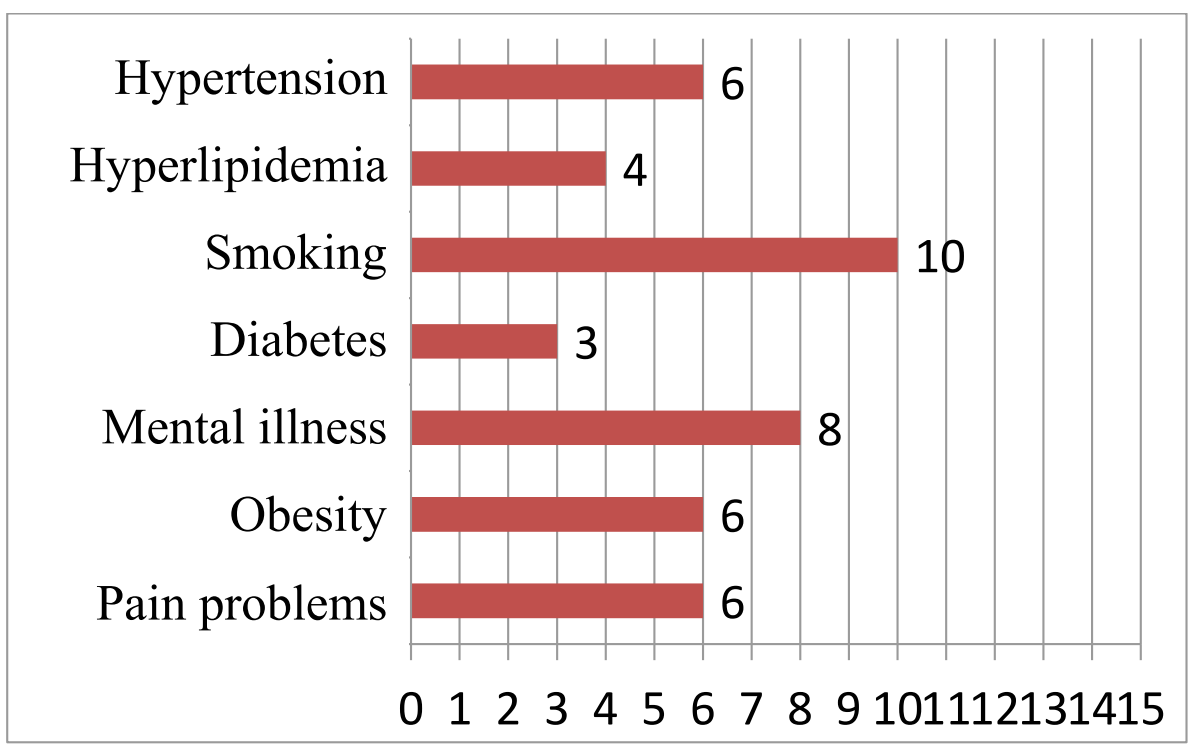

Figure 7. A review of the medical records was carried out, to complement the data from the interviews regarding diagnosis for hypertension, hyperlipidemia, diabetes, mental illness, pain problems, obesity and smoking. 


\section{Paper III}

Mean age for the women in the high level Good Girl group was 52.1 years , and 53.1 years for those in the low level Good Girl group. As for distribution in the white-collar and the blue-collar city, there was no statistically significant difference in the various groups $(\mathrm{p}=0.834)$. A significantly higher education level $(62 \%$ versus $48 \%, \mathrm{p}=0.001$ ) was found among women in the high level Good Girl group compared to the low level Good Girl group. Regarding sociodemographic characteristics, there were no other significant differences between the groups.

Table 6. Social characteristics for the two group's high level v.s. low level Good Girl.

\begin{tabular}{|c|c|c|c|c|c|c|}
\hline & \multicolumn{2}{|c|}{$\begin{array}{l}\text { High level Good Girl group } \\
\qquad \mathrm{n}=112\end{array}$} & \multicolumn{2}{|c|}{$\begin{array}{l}\text { Low level Good Girl group } \\
\qquad \mathrm{n}=629\end{array}$} & \multirow[b]{2}{*}{ p-value } & \multirow[b]{2}{*}{ p-value\# } \\
\hline & $\%$ & $\mathrm{n}$ & $\%$ & $\mathrm{n}$ & & \\
\hline \multicolumn{7}{|l|}{ Education level } \\
\hline Elementary school & 4.5 & (5) & 12.8 & (80) & & \\
\hline High school & 34.2 & $(38)$ & 40.3 & (251) & & \\
\hline University & 61.3 & $(68)$ & 46.9 & (292) & 0.005 & 0.001 \\
\hline \multicolumn{7}{|l|}{ Accommodation } \\
\hline Living in own house & 56.3 & (63) & 54.6 & (343) & 0.749 & 0.660 \\
\hline \multicolumn{7}{|l|}{$\begin{array}{l}\text { Care Need Index related to } \\
\text { residential area }\end{array}$} \\
\hline Low residential area & 59.8 & $(67)$ & 55.8 & $(351)$ & & \\
\hline Medium/High residential area & 40.2 & $(45)$ & 44.2 & (278) & 0.429 & 0.989 \\
\hline \multicolumn{7}{|l|}{ Social environment } \\
\hline White collar city & 55.4 & $(62)$ & 51.8 & (326) & & \\
\hline Blue collar city & 44.6 & $(50)$ & 48.2 & (303) & 0.491 & 0.834 \\
\hline \multicolumn{7}{|l|}{ Economy } \\
\hline $\begin{array}{l}\text { Able to obtain } 15000 \text { SEK } \\
\text { in a week }\end{array}$ & 85.6 & (95) & 84.4 & (525) & 0.751 & 0.618 \\
\hline \#P-value adjusted for educatio & idential a & & & & & \\
\hline
\end{tabular}


There were significant differences between the two groups in nearly all of the 12 items in the General Health Questionnaire (GHQ-12) measuring psychological distress. More psychological distress was reported in the high level Good Girl group compared to the low level Good Girl group, except for the item "Able to enjoy day-to-day activities" $(\mathrm{p}=0.179)$ and "Felt playing useful part in things" $(\mathrm{p}=0.080)$.

Table 7. Self-reported mental well-being.

\begin{tabular}{|c|c|c|c|c|c|c|}
\hline & \multicolumn{2}{|c|}{ GGPT group n=112 } & \multicolumn{2}{|c|}{ REF group $n=629$} & \multirow[b]{2}{*}{$P$-value } & \multirow[b]{2}{*}{ P-value\# } \\
\hline & $\%$ & (n) & $\%$ & (n) & & \\
\hline \multicolumn{7}{|l|}{ Able to concentrate } \\
\hline Less than usual & 18.0 & 20 & 10.1 & 63 & 0.015 & 0.011 \\
\hline \multicolumn{7}{|c|}{ Felt playing useful part in things } \\
\hline Less than usual & 15.3 & 17 & 10.9 & 68 & 0.180 & 0.179 \\
\hline \multicolumn{7}{|c|}{ Lost sleep over worry } \\
\hline More than usual & 22.6 & 24 & 9.3 & 58 & $<0.0001$ & $<0.0001$ \\
\hline \multicolumn{7}{|c|}{ Felt couldn't overcome difficulties } \\
\hline Less than usual & 18.0 & 20 & 6.9 & 43 & $<0.0001$ & $<0.0001$ \\
\hline \multicolumn{7}{|l|}{ Been feeling useful } \\
\hline Less than usual & 10.8 & 12 & 6.7 & 42 & 0.125 & 0.080 \\
\hline \multicolumn{7}{|c|}{ Been feeling unhappy and depressed } \\
\hline More than usual & 19.8 & 22 & 9.8 & 61 & 0.002 & 0.001 \\
\hline \multicolumn{7}{|c|}{ Felt capable of making decision } \\
\hline Less than usual & 10.8 & 12 & 5.0 & 31 & 0.016 & 0.011 \\
\hline \multicolumn{7}{|c|}{ Been losing confidence in self } \\
\hline More than usual & 14.5 & 16 & 4.8 & 30 & $<0.0001$ & $<0.0001$ \\
\hline \multicolumn{7}{|c|}{ Felt constantly under strain } \\
\hline More than usual & 26.1 & 29 & 11.8 & 74 & $<0,0001$ & $<0.0001$ \\
\hline \multicolumn{7}{|c|}{ Been thinking of self as worthless } \\
\hline More than usual & 14.4 & 16 & 5.3 & 33 & $<0,0001$ & $<0.0001$ \\
\hline \multicolumn{7}{|c|}{ Not been able to face problems } \\
\hline More than usual & 22.5 & 25 & 7.0 & 44 & $<0.0001$ & $<0.0001$ \\
\hline \multicolumn{7}{|c|}{ Been feeling reasonably happy } \\
\hline Less than usual & 16.2 & 18 & 8.3 & 52 & 0.009 & 0.019 \\
\hline \multicolumn{7}{|c|}{ Do you feel stressed at present } \\
\hline More than usual & 27.7 & 31 & 10.0 & 63 & $<0.0001$ & $<0.0001$ \\
\hline
\end{tabular}

\#P-value adjusted for education and residential area. 
The GHQ total score was also significantly higher among the women in the high level Good Girl group, $(\mathrm{p}<0.001)$.

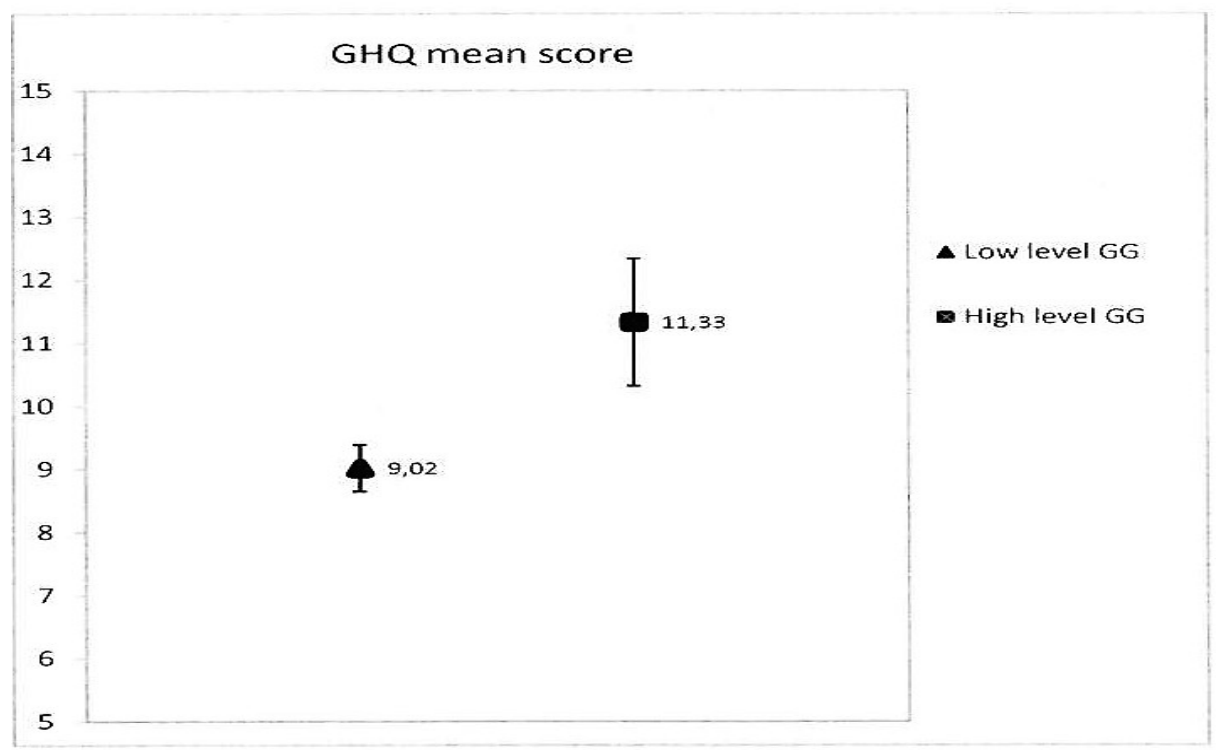

Figur 8. General Health Questionnaire (GHQ) mean score for the two study groups, High level Good Girl group and Low level Good Girl group. The score ranges from $0-36$ points. A higher score indicates a greater degree of psychological distress.

The GHQ total score was also significantly higher among the women in the high level Good Girl group, ( $\mathrm{p}<0.001)$.The women in the high level Good Girl group were significantly less physically active compared to those in the low level Good Girl group $(\mathrm{p}=0.016)$, after adjusting for educational level and residential area. As for eating vegetables, there were also significant differences between the groups; the high level Good Girl group ate less vegetables compared to the low level Good Girl group ( $\mathrm{p}=\mathbf{0 . 0 3 3 )}$.

The same pattern is shown for anxiety ( $p$ o.033) and tiredness $(p=0.018)$. The women in the high level Good Girl group reported significantly more problems than those in the low level Good Girl group, before and after adjustment for education and residential area. 
Table 8. Mental health indicator. The high level Good Girl group reported significantly more "Consider themselves to be pedantic" ( $\mathrm{p}=>0.0001$ vs. adjusted $\mathrm{p}=>0.0001)$, and "Refrain medical consulting despite the need", $(\mathrm{p}=0.001)$, even after adjustment for education and residential area $(\mathrm{p}=0.001)$.

Table 8. Mental health indicators.

\begin{tabular}{|c|c|c|c|c|c|c|}
\hline & \multicolumn{2}{|c|}{$\begin{array}{l}\text { High level Good Girl group } \\
\qquad \mathrm{n}=112\end{array}$} & \multicolumn{2}{|c|}{$\begin{array}{l}\text { Low level Good Girl group } \\
n=629\end{array}$} & \multirow[b]{2}{*}{ p-value } & \multirow[b]{2}{*}{ p-value\# } \\
\hline & $\%$ & $\mathrm{n}$ & $\%$ & $\mathrm{n}$ & & \\
\hline \multicolumn{7}{|l|}{ Doctor diagnosed: } \\
\hline $\begin{array}{l}\text { Depression- } \\
\text { recurrent depression }\end{array}$ & 16.1 & 18.0 & 9.7 & 61.0 & 0.044 & 0.062 \\
\hline Anxiety & 10.7 & 12.0 & 9.2 & 58.0 & 0.619 & 0.672 \\
\hline \multicolumn{7}{|l|}{ Self-reported: } \\
\hline Drug for Depression & 10.9 & 11.0 & 10.7 & 61.0 & 0.964 & 0.916 \\
\hline Anxiety & 40.2 & 45.0 & 30.7 & 192.0 & 0.048 & 0.033 \\
\hline Drug for Anxiety & 5.1 & 5.0 & 8.9 & 50.0 & 0.319 & 0.381 \\
\hline Sleep disturbances & 45.9 & 51.0 & 41.0 & 257.0 & 0.329 & 0.192 \\
\hline Tiredness & 54.5 & 61.0 & 43.3 & 272.0 & 0.029 & 0.018 \\
\hline $\begin{array}{l}\text { Refrains from medical } \\
\text { consultation, despite the ncc }\end{array}$ & 31.8 & 34.0 & 17.1 & 103.0 & 0.001 & 0.001 \\
\hline $\begin{array}{l}\text { Consider themselves to be } \\
\text { pedantic }\end{array}$ & 82.0 & 73.2 & 34.7 & 55.9 & $>0.0001$ & $>0.0001$ \\
\hline
\end{tabular}

The high level Good Girl group was more often diagnosed with depression $(\mathrm{p}=0.044)$, than those in the low level Good Girl group. However, this difference did not persist after adjustment for education and residential area $(p=0.062)$. There were no statistically significant differences with regard to other medical problems between the groups, except for self-reported chest pain; the high level Good Girl group reported significantly more problems in relation to the low level Good Girl group, before and after adjustment for education and residential area $(\mathrm{p}=0.016)$ and $(\mathrm{p}=0.004)$.

\section{Paper IV}

We compared middle-aged women in urban areas in Sweden and Scotland regarding risk factors for CVD (including lifestyle), a history of CVD diagnosis and psychological distress. The mean age of the participating women was similar in both countries. Swedish women were almost $5 \mathrm{~cm}$ taller than the Scottish women $(\mathrm{p}=0.001)$. Scottish women were also less educated than the Swedish women OR $=3.31$ (CI 95\%=1.58-4.25).

Longstanding illness was more common OR=1.57 (CI 95\%=1.35-1.84) among Scottish women than in the Swedish women, and the same was found for self- 
assessed bad general health among the Scottish women OR=2.47 (CI95\%=1.703.59).

Table 9. Background characteristics for the participating women from Scotland and Sweden, and OR-calculations.

\begin{tabular}{|c|c|c|c|c|c|c|c|c|c|}
\hline & \multicolumn{2}{|c|}{$\begin{array}{l}\text { Scotland } \\
\mathrm{N}=6.250\end{array}$} & \multicolumn{2}{|c|}{$\begin{array}{l}\text { Sweden } \\
\mathrm{N}=741\end{array}$} & p-value & OR & CI $95 \%$ & OR\# & CI $95 \%$ \\
\hline \multicolumn{10}{|l|}{ Age } \\
\hline $\operatorname{Mean}( \pm S D)$ & \multicolumn{2}{|c|}{$52.2(7.6)$} & \multicolumn{2}{|c|}{$52.7(7.7)$} & 0.137 & & & & \\
\hline \multicolumn{10}{|l|}{ Height } \\
\hline \multirow[t]{2}{*}{$\operatorname{Mean}( \pm S D)$} & \multicolumn{2}{|c|}{$161.1(6.4)$} & \multicolumn{2}{|c|}{$166.03(6.5)$} & 0.001 & & & & \\
\hline & $\mathbf{n}$ & $\%$ & $\mathbf{n}$ & $\%$ & & & & & \\
\hline \multicolumn{10}{|l|}{$\begin{array}{l}\text { Self-assessed } \\
\text { general health: }\end{array}$} \\
\hline Good & 4533 & 72.5 & 542 & 73.4 & & & & & \\
\hline Fair & 1125 & 18.0 & 166 & 22.5 & & & & & \\
\hline Bad & 592 & 9.5 & 30 & 4.1 & & 2.47 & $1.70-3.59$ & 1.79 & $1.22-2.64$ \\
\hline \multicolumn{10}{|l|}{$\begin{array}{l}\text { Longstanding } \\
\text { illness: }\end{array}$} \\
\hline Yes & 3003 & 48.0 & 272 & 37.0 & & 1.57 & $1.35-1.84$ & 1.44 & $1.22-1.70$ \\
\hline No & 3247 & 52.0 & 463 & 63.0 & & & & & \\
\hline \multicolumn{10}{|l|}{ Education: } \\
\hline Low education & 1955 & 31.4 & 85 & 11.6 & & 3.31 & $1.58-4.25$ & $4.13 \# 2$ & $3.17-5.37$ \\
\hline Medium education & 2009 & 32.3 & 289 & 39.4 & & & & & \\
\hline High education & 2265 & 36.4 & 360 & 49.0 & & & & & \\
\hline
\end{tabular}

There were differences in lifestyle risk factors between the Scottish and Swedish women, favoring the Swedish women. This was evident for smoking $\mathrm{OR}=1.53$ (CI 
95\%=1.27-1.86), alcohol consumption $\mathrm{OR}=4.23$ (CI 95\%=3.59-4.97), vegetable consumption $\mathrm{OR}=5.37$ (CI 95\%=4.00-7.21), fruit consumption $\mathrm{OR}=1.53$ (CI $95 \%=1.23-1.90)$, and sedentary lifestyle $\mathrm{OR}=2.28(\mathrm{CI} 95 \%=1.74-3.01)$.

Table 10. Descriptions of lifestyle among participating middle-aged women from Scotland and Sweden, and OR-calculations.

\begin{tabular}{|c|c|c|c|c|c|c|c|c|}
\hline & \multicolumn{2}{|c|}{$\begin{array}{l}\text { Scotland } \\
N=6.250\end{array}$} & \multicolumn{2}{|c|}{$\begin{array}{l}\text { Sweden } \\
N=741\end{array}$} & \multirow[t]{2}{*}{ OR } & \multirow[t]{2}{*}{ CI $95 \%$} & \multirow[t]{2}{*}{ OR\# } & \multirow[t]{2}{*}{ CI 95\% } \\
\hline & $\mathbf{n}$ & $\%$ & $\mathbf{n}$ & $\%$ & & & & \\
\hline \multicolumn{9}{|l|}{ Smoking } \\
\hline Yes & 1694 & 27.2 & 143 & 19.6 & 1.53 & $1.27-1.86$ & 1.23 & $1.01-1.50$ \\
\hline No & 4545 & 72.8 & 588 & 80.4 & & & & \\
\hline \multicolumn{9}{|l|}{$\begin{array}{l}\text { Drink } \\
\text { alcohol }\end{array}$} \\
\hline Often & 3325 & 53.3 & 248 & 33.7 & 4.23 & $3.59-4.97$ & 5.27 & $4.46-6.24$ \\
\hline Seldom & 2909 & 46.7 & 487 & 66.3 & & & & \\
\hline \multicolumn{9}{|l|}{$\begin{array}{l}\text { Physical } \\
\text { inactivity }\end{array}$} \\
\hline Sedentary & 1044 & 16.8 & 59 & 8.1 & 2.28 & $1.74-3.01$ & 1.80 & $1.36-2.39$ \\
\hline Not sedentary & 5182 & 83.2 & 670 & 91.9 & & & & \\
\hline \multicolumn{9}{|l|}{ Eating fruit } \\
\hline Often & 4999 & 80.0 & 632 & 86.0 & & & & \\
\hline Seldom & 1248 & 20.0 & 103 & 14.0 & 2.28 & $1.74-3.01$ & 1.80 & $1.36-2.39$ \\
\hline \multicolumn{9}{|l|}{$\begin{array}{l}\text { Eating } \\
\text { vegetables }\end{array}$} \\
\hline Often & 4517 & 72.3 & 687 & 93.3 & & & & \\
\hline Seldom & 1730 & 27.7 & 49 & 6.7 & 5.37 & $4.00-7.21$ & 4.70 & $3.47-6.36$ \\
\hline
\end{tabular}

\#OR adjusted for age and education 
The General Health Questionnaire total scores were significantly higher $(\mathrm{p}<0.0001)$ for Scottish women (mean score $=1.77$ ) than the Swedish women (mean score=1.12).

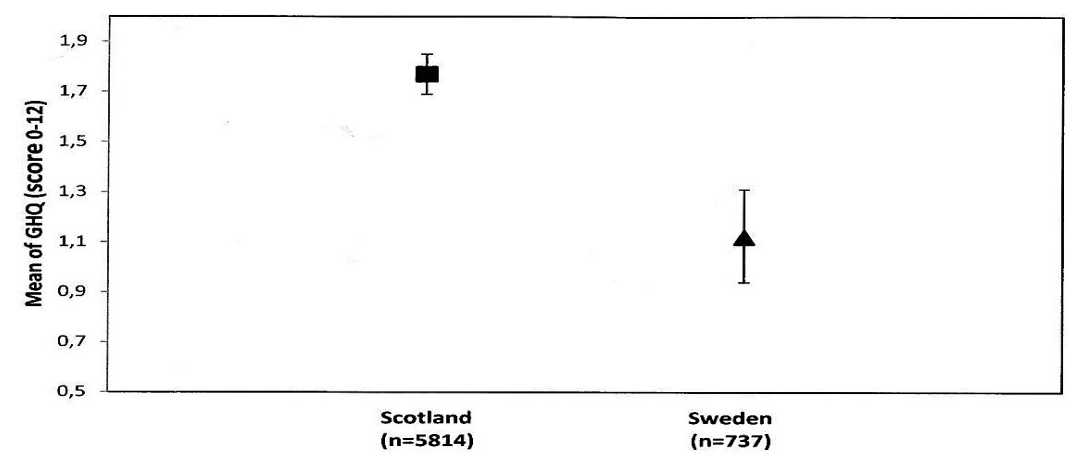

Figure 9. General Health Questionnaire 12 (GHQ 12) (with 95\% confidence intervals) for middle-aged women in Scotland and Sweden. The General Health Questionnaire - GHQ 12, included in the survey provides a standardized way to summarize the answers in a score, ranging from 0-12 points. A higher score indicates a higher degree of psychological distress.

The General Health Questionnaire total scores were significantly higher $(p<0.0001)$ for Scottish women (mean score $=1.77$ ) than the Swedish women (mean score $=1.12$ ).

There were differences in almost all questions in the GHQ between the two countries, favoring the Swedish women, particularly "Lost sleep over worry" OR=2.01 (CI 95\%=1.582.55), "Been feeling unhappy and depressed" OR=1.93 (CI $95 \%=1.52-2.45$ ), "Been losing confidence in self" OR=2.91 (CI 95\%=2.15-3.96) and "Felt constantly under strain" OR=1.85 (CI 95\%=1.49-2.30). 
Risk factors for hypertension and CVD, there were twice as many OR=2.71 (CI 95\% 2.19-3.35) obese Scottish women compared to their Swedish counterparts. In Scotland, more women than in Sweden reported hypertension OR=1.81 (CI $95 \%=1.50-2.91$ ), and diagnosed hypertension (OR 1.69, CI 95\%=1.38-2.06) (Table X)

Table 11. Risk factors for CVD among participating middle-aged women in Scotland and Sweden.

\begin{tabular}{|c|c|c|c|c|c|c|c|c|}
\hline & \multicolumn{2}{|c|}{$\begin{array}{l}\text { Seotland } \\
N=6.250\end{array}$} & \multicolumn{2}{|c|}{$\begin{array}{l}\text { Sweden } \\
\mathrm{N}=741\end{array}$} & \multirow[t]{2}{*}{ OR } & \multirow[t]{2}{*}{ CI $95 \%$} & \multirow[t]{2}{*}{ OR\# } & \multirow[t]{2}{*}{ CI $95 \%$} \\
\hline BMI & $\mathbf{n}$ & $\%$ & $\mathbf{n}$ & $\%$ & & & & \\
\hline Underweight-BMI<18.5 & 42 & 0.8 & 10 & 1.4 & & & & \\
\hline Normal Weight-18.5-24.9 & 1619 & 30.9 & 373 & 51.6 & & & & \\
\hline Overweight-BMI $25-29.9$ & 1878 & 35.8 & 231 & 32.0 & & & & \\
\hline Obese-BMI 30-50 & 1701 & 32.5 & 109 & 15.1 & 2.71 & $2.19-3.35$ & 2.59 & $2.09-3.21$ \\
\hline \multicolumn{9}{|l|}{$\begin{array}{l}\text { High blood pressure } \\
\text { (Self-Reported) }\end{array}$} \\
\hline Yes & 1886 & 30.2 & 142 & 19.3 & 1.81 & $1.50-2.91$ & 1.72 & $1.42-2.10$ \\
\hline No & 4359 & 69.8 & 594 & 80.7 & & & & \\
\hline \multicolumn{9}{|l|}{$\begin{array}{l}\text { \$High blood pressure } \\
\text { (doctor-diagnosed) }\end{array}$} \\
\hline Yes & 1595 & 25.5 & 125 & 16.9 & 1.69 & $1.38-2.06$ & 1.61 & $1.31-1.99$ \\
\hline No & 4655 & 74.5 & 616 & 83.1 & & & & \\
\hline
\end{tabular}

\#OR adjusted for age and education. $\ddagger$ Swedish data derive from medical records while Scottish data are based on self-reported doctor-diagnosed hypertension. 
There were differences between the countries for the variable "CHD" (including angina pectoris and myocardial infarction), with a higher prevalence in the Scottish women $\mathrm{OR}=4.81(\mathrm{CI} 95 \%=2.47-9.36)$. Angina pectoris alone was also more common in the Scottish women than in the Swedish OR=4.47 (CI $95 \%=1.9810 .09$ ). The picture is the same for myocardial infarction OR 3.12 (CI $95 \%=1.15-8.49$ ), the low numbers among the Swedish women are noticeable, particularly with regard to all CHD-diagnoses.

Table 12. Doctor-diagnosed CVD among participating middle-aged women in Scotland and Sweden.

\begin{tabular}{|c|c|c|c|c|c|c|}
\hline & \multicolumn{2}{|c|}{$\begin{array}{l}\text { Scotland } \\
\mathbf{N}=6.250\end{array}$} & \multicolumn{2}{|c|}{$\begin{array}{l}\text { Sweden } \\
\mathbf{N}=\mathbf{7 4 1}\end{array}$} & \multirow[t]{2}{*}{ OR } & \multirow[t]{2}{*}{ CI 95\% } \\
\hline & $\mathbf{n}$ & $\%$ & n & $\%$ & & \\
\hline $\begin{array}{l}\text { †Angina pectoris: } \\
\text { Yes } \\
\text { No }\end{array}$ & $\begin{array}{l}220 \\
6030\end{array}$ & $\begin{array}{l}3.5 \\
96.5\end{array}$ & $\begin{array}{l}6 \\
735\end{array}$ & $\begin{array}{l}0.8 \\
99.2\end{array}$ & 4.47 & $1.98-10.09$ \\
\hline $\begin{array}{l}\text { \yyocardial } \\
\text { infarction (MI) } \\
\text { Yes } \\
\text { No }\end{array}$ & $\begin{array}{l}104 \\
6146\end{array}$ & $\begin{array}{l}1.7 \\
98.3\end{array}$ & $\begin{array}{l}4 \\
737\end{array}$ & $\begin{array}{l}0.5 \\
99.5\end{array}$ & 3.12 & $1.15-8.49$ \\
\hline $\begin{array}{l}\text { †Stroke/TIA: } \\
\text { Yes } \\
\text { No }\end{array}$ & $\begin{array}{l}124 \\
6126\end{array}$ & $\begin{array}{l}2.0 \\
98.0\end{array}$ & $\begin{array}{l}10 \\
731\end{array}$ & $\begin{array}{l}1.3 \\
98.7\end{array}$ & 1.48 & $0.77-2.83$ \\
\hline $\begin{array}{l}\ddagger \text { CVD (angina, MI } \\
\text { stroke) } \\
\text { Yes } \\
\text { No }\end{array}$ & $\begin{array}{l}265 \\
5985\end{array}$ & $\begin{array}{l}4.2 \\
95.8\end{array}$ & $\begin{array}{l}23 \\
718\end{array}$ & $\begin{array}{l}3.1 \\
96.9\end{array}$ & 1.38 & $0.90-2.13$ \\
\hline $\begin{array}{l}\text { ¥CHD (angina, MI) } \\
\text { Yes } \\
\text { No }\end{array}$ & $\begin{array}{l}349 \\
5901\end{array}$ & $\begin{array}{l}5.6 \\
94.4\end{array}$ & $\begin{array}{l}9 \\
732\end{array}$ & $\begin{array}{l}1.2 \\
98.8\end{array}$ & 4.81 & $2.47-9.36$ \\
\hline
\end{tabular}

\#OR adjusted for age and education. $\$$ Swedish data derive from medical records while Scottish data are based on self-reported, doctor-diagnosed diseases. 


\section{DISCUSSION}

\section{Overview and main results in the papers}

This thesis started with a comparison of cardiovascular morbidity and mortality in two different social environments, a blue collar and a white collar city, referred to as the Twin cities. Profound differences in cardiovascular morbidity and mortality between these cities were found, where the population in the blue- collar city was the most affected. These differences in cardiovascular risks also seem to be stable over time.

Our initial findings inspired us to dig deeper into the issue of cardiovascular risks and middle-aged women. Who are these middle-aged women who suffered a myocardial infarction and what were their lives like before they became ill. To shed some light on these questions, a qualitative interview study was conducted, focusing on middle-aged women who had recently suffered from a myocardial infarction. The findings revealed a broad picture of social factors, life circumstances, personalities and, not least, psychosocial factors that are important to middle-aged women who have suffered an MI. The psychosocial phenomenon to strive "to be a good girl" was a personality trait also found, to which these women had been shaped throughout their lives.

A quantitative study of middle-aged women within the frame of the Twin cities, the QWIN-study, was the next step. This study indicated that women with a high level of the personality trait labeled "being a Good Girl" have more psychological distress, a higher incidence of diagnosed depression and self-reported anxiety, tiredness, "consider themselves to be pedantic", and more often report chest pain without seeking medical care. However, no increased prevalence of cardiovascular diseases was found among women in the high level Good Girl group compared to the low level Good Girl group.

To further elaborate on the importance of the social environment and cardiovascular risks, a study comparing the differences between Scotland and Sweden was carried out. The population of Scotland is known to have one of the highest cardiovascular mortality rates in western Europe.

This study focused on middle-aged women and cardiovascular risk factors, morbidity and lifestyle factors. This comparative study clearly showed that Scottish middle-aged women are - relative to Swedish women - particularly affected by a worse profile of CVD risks, even after adjustment for education.

\section{The social environment}

The society's hierarchical structures have consequences for health and the individual's position in that structure has consequences for health. Groups with a higher position in the social hierarchy, have more influence and money, better housing, jobs with status, and so on, while groups with a lower position have access to fewer of these resources. Good health and a long life are strongly connected with a higher position in the hierarchical structures. Groups in a higher position have better health, irrespective of where they are in the social hierarchy, and those who are further down the hierarchy have a poorer health in relation to their position. In other words, health follows a social gradient (Marmot, 2015). 
Twin cities - comparing a blue collar and a white collar city

Differences in risks for cardiovascular morbidity and mortality were found between the populations in a "blue-collar" and a "white-collar" city, and these seem to be profound and stable over time. The Twin cities are quite comparable, even though they historically represented different social environments, a blue collar and a white collar city. It has been known for long that there is a close link between socioeconomic factors and cardiovascular morbidity (Lunch et al, 1996). In men as well as women, low socioeconomic status is associated with an increased risk of CVD (Alboni P et al, 2003, Osler et al, 2000, Wilkinson, 2005).

A study from northern Sweden supported this, where both a higher incidence of and higher mortality due to myocardial infarction and stroke were found amongst blue-collar workers related to respondents in non-manual occupations (Peltonen et al, 2000). Great differences in cardiovascular risk profiles between skilled and unskilled blue-collar workers have also been found (Dorner et al, 2006).

When analyzing cardiovascular risk determinants, individual behavior and lifestyle, and thereby socioeconomic factors, are of importance (McGrath et al, 2006). A good proxy for socioeconomic status is the highest attained educational level. In a socioeconomic context, educational level is furthermore the strongest component (Faresjö et al, 2010).

Not only living conditions are reflected by education level, but also attitudes and health behavior in general. The variation in educational level in the population in the studied twin cities might contribute to the disparities in risk of cardiovascular disease. It is more likely to find different health behaviors, lifestyles, consumption patterns and dietary habits in a city with a mix of more highly educated people (the white collar city), than in a city with less educated people (the blue collar city). This implies that there are differences in the risk of suffering cardiovascular disease between these two cities. In other studies were found connections between neighborhood socioeconomic characteristics in the population and hypertension risk to be refereed by changes in body mass index. (Chaix et al, 2010). This indicates that dietary habits are closely associated to educational level. There is also research that has proposed that people closest friends are obese also tend to have a risk of becoming obese over time (Christakis et al, 2007). Health behavior seems to be created in micro-systems and in close social relationships within a society. Communities with more educated people, even in the social micro-systems, thereby tend to display a variation of lifestyles and cardiovascular risks than in societies with less educated people. Exclusive social norms grow in cultural groups and subgroups in a society. These norms involve explicit as well as implicit rules for what attitudes and behaviors are suitable in this particular group.

If individuals do not follow the rules they might be excluded from the group. The reason why a community-based program might be more successful than individual programs could be explained by these mechanisms (Zhang X et al 2010). In addition, the powerlessness of people, as well as relatively poor working conditions, are detrimental for health.

The blue collar city was "a town of sorrow", until the last 10-15 years, with an old structure and a history of closed factories. All these aspects might have influenced the risk for cardiovascular disease in the population. 
However, in the last decade, the university has established a university campus in the blue collar city, which can have positive effects on health. Today, many social structures in the blue collar city have surpassed the structures of the neighboring white collar city, but public health differences still seem to prevail. The white collar city has undergone a strong economic and population growth throughout the $20^{\text {th }}$ century, particularly during the post-war era. The establishment of an aerospace industry created a demand for engineers and in that way established the white collar city as a high technology city. This city succeeded to turn around an unstable situation in the 1960's, primarily through the establishment of the Technical University College and finally a fully-fledged university. A successful collaboration between the university and the county council led to the establishment of a medical faculty in the 1980's. The political and economic triumph of a city is possibly a health-promoting factor in itself. A segregated industry leading to a varied labor market in the white collar municipality was indeed even more essential. The change from an industrial society to a technological information society was more rapid than in the neighboring blue collar city. On the other hand, there has been a rising income gap and increasing ethnical segregation in the white collar city in the last decade.

\section{Comparing Scotland and Sweden}

One finding in this thesis was that Scottish women tend to have a higher alcohol consumption than Swedish women. There are numerous potential explanations. There is a Nordic model of alcohol control, particularly in Sweden, with the exception of Denmark, characterized by high taxation and restrictions on alcohol sales (Rabinovich et al, 2009). This has been related to reduced alcohol consumption, lower levels of liver cirrhosis mortality and other alcohol-related mortality, and the social problems that alcohol generates. Historically, Scotland (and the UK) has a tolerant attitude to alcohol and a "wet" drinking culture, whereby complete abstinence is atypical and consumption is central to everyday life (Bloomfield et al, 2003). In an attempt to reduce alcohol-related harm in Scotland, a range of policies have been introduced in recent years, but the influence of such interventions will take time to establish in the population (NHS, 2016). Resent estimates show increasing sales of alcohol in Scotland. This is particularly true of supermarkets and off-licences where prices have been stable, whereas there has been a fall in sales in licensed premises where prices have been rising (NHS, 2016). The alcohol control policies in the Nordic countries is one example of a policy area of strong interest because of the health benefits it could indicate (Lundberg et al, 2008). The discrepancy in obesity rates is also striking. Self-reported BMI data, as collected in the Swedish survey, has a propensity to underestimate obesity prevalence. Nevertheless, the reported obesity prevalence for Swedish women in this study (15\%) corresponds with that recorded for all Swedish adults in 2016 (Public Health, 2016).

Several women in Scotland also reported worse psychosocial health and poorer general health. Even though we adjusted for education level, this sociodemographic variable was the one most significantly related with social class differences in chronic disease rates. 
Nearly all the measures of CVD risk factors and outcomes exposed considerably worse profiles among the middle-aged Scottish women than in their Swedish matches.

Scottish women reported higher levels of psychological distress than Swedish women. The impact of inequality on the quality of social relationships and the scale of status differentiation in the two societies is likely to be related to these differences. It has been shown in other studies that larger income inequalities in rich societies are related with higher levels of drug abuse and mental illness (Pickett \& Wilkinson, 2010).

Severe cardiovascular diseases are rather uncommon among middle-aged women. Still, we found a 3.1- to 4.8-fold higher prevalence (OR) of doctor-diagnosed angina pectoris, myocardial infarction, and CHD (both combined), in the Scottish women compared to the Swedish women. This result should be interpreted with caution due to the low numbers, particularly in the Swedish women. It is likely that these profound differences in CVD risk and outcome frequency have arisen from differences in the social, cultural, political and economic environments in which the two groups of women live. In Scotland overall (compared to most of Western Europe), worse health status, and worse health inequalities by social class is well documented (Frank et al, 2015, Wolfe et al, 2015, Schofield et al, 2016).

As shown in other studies, large income differences, are harmful to health and the cause of social costs. In many western countries the income inequality is increasing, but it is greater in Scotland than in Sweden. To improve health, it is important to take into account that an ongoing work is required to decrease inequalities (Pickett \& Wilkinson, 2015). The role of the social, economic and cultural factors, is more evident in women, when determining such a frequent disease as CVD. Societal development has resulted in increased labor force participation among women and thereby changed their economic role. When describing the epidemiology of CVD and its risk factors in European women, this development cannot be overlooked (Panico \& Mattiello, 2010).

The Nordic welfare states are distinguished by their emphasis on universal social policies rather than a reliance on targeted, selective and means-tested policies. Reducing poverty and fostering equality of opportunity as well as equality of outcomes in terms of class, income and gender, has been successful in the Nordic countries. One way to affect public health positively may be made by several citizens served on welfare resources through welfare state institutions and with a universal social policy. Authority over the resources by which we can control and intentionally manage our conditions of life is of crucial significance to health. Both material and intangible resources are included (Lundberg et al, 2008, Marmot 2007).

Individuals with minor material and intangible resources tend to lose the reason to take care of their own health. Could these factors contribute to why there are higher levels of obesity, alcohol consumption and sedentary behavior in women in Scotland? 
In addition, there are important regulatory differences; Sweden has stricter regulations of the food environment, much stricter alcohol control policies (both price and supply), and the transport infrastructure gives more opportunities for walking and cycling and less reliance on cars.

\section{Psychosocial risk factors for CVD}

The risk of developing CVD and the worsening of clinical outcome and prognosis of the disease, is affected of low socioeconomic status, lack of social support, stress at work and in family life, depression, anxiety, hostility, and the type D personality. These factors complicate the possibility of an improved lifestyle and impede treatment recommendations, as well as to promote health and well-being in patients and the population. However, distinct psychobiological mechanisms have been found, which are immediately included in the pathogenesis of CVD (Perk, 2012).

\section{The qualitative interview study}

Although several women presented some classic risk factors such as overweight and smoking, a variety of psychosocial factors likewise appeared, which provided a better understanding of the causal chains for women's risk of suffering an MI. Some of the women who had suffered an MI had well-controlled classic risk factors, but poorly controlled psychosocial risk factors, as shown in previous studies (Albus et al, 2004). Research has started to gradually provide evidence on the fact that the causality pattern for CVD is multifaceted and that psychosocial factors complement the classic risk factors. Psychosocial stress is notably more pronounced in women and constitutes an important risk factor for cardiovascular diseases (Perk, 2012). Nevertheless, this could only be somewhat explained by the trend of more unhealthy behaviors in this group (Yusuf et al, 2004, Kop et al, 1997)

A general impression of the qualitative interviews with the women was that they all had a tendency to demonstrate both anger and stress but turn it on themselves. This could be referred to as inward stress or an internal strain. This phenomenon also reflects the vulnerability and serious life experiences among these women. One thought is that these women are formed from all negative life events, betrayal and loneliness in close relationships, for a long time, which also shaped their personalities.

Several of the interviewed women, particularly those of working ages, could be considered as having a low socioeconomic status and were poorly educated (Reinier et al, 2011). Women's feelings of lack of control of their life contribute to stress at work, resulting in conflicts and layoffs. In addition, a lack of social support accentuates the risk presented by work-related psychosocial factors (Kivimäki et al, 2006). Women reported stressful social life situations in general and in their close family, which likewise comprise risk factors for MI (Perk et al, 2012, Low et al, 2010). A feeling of loneliness due to a lack of social support in the close family is also a risk factor, as well as experiences of serious life events (Perk et al, 2012, Gonzalez et al, 2009). 
"The broken heart syndrome", believed to arise from strong physical or emotional stress, might cause spasms in the blood vessels, and it is particularly pronounced among women (Hallman et al, 2001, Low et al, 2010). This phenomenon might explain the incidence of the disease in some of the women we studied. Several of the women seemed to be hostile, had negative thoughts, suffered from depression/anxiety and suppressed anger. Other studies have shown these factors to increase the risk of MI. On the contrary, positive thinking and an optimistic view of life seem to be protective factors (Perk, 2012, Denollet et al, 2010, Tindle et al, 2009).

"Being a Good Girl" was another characteristic among the interviewed women. They felt squeezed between family life and work, which has earlier been reported to be related to risk of cardiovascular disease (Hallman et al, 2001).

This feature moreover signifies a strife to improve one's low self-esteem, which has been found to lead to over-ambition and a neglect of one's mental and physical limits (Johnson et al, 1995). Feelings of frustration in performance situations, displaying high emotional tension, strong control needs, maladaptive strivings, perfectionism, and a hostile attitude towards others are characteristics of these individuals (Forsman \& Johnson, 1996, Koivula et al, 2002, Blom, 2011). These psychosocial factors could be seen in a gender-specific perspective, where female role models in the society might have influenced the personal characteristics of these women. Myocardial infarction is still considered to be a predominantly male disease. This, among other things, explains the tendency among women to delay seeking care. They also have more problems accepting the disease compared to men (Maas et al, 2011, Wenger, 2010, Hallman et al, 2001). All women in the interview study did not believe they were suffering an MI when having symptoms, and some could not tolerate the MI diagnosis even after a year. The same phenomenon was also found among the high level Good Girl group in the QWIN-study, where there was a higher frequency of self-reported chest pain. This group of women also reported that they refrained from seeking medical care despite the need to do so.

\section{Risk factor for CVD and personality traits}

Being a Good Girl might be a personality trait with higher risk factors for CVD. A higher prevalence of self-reported chest pain was seen in the high level Good Girl group. Another study revealed that patients with unexplained chest pain were likely to be immigrants, they perceived more stress at work and had more symptoms of depression and trait-anxiety compared with the participants in the reference group, even after adjustment for age, smoking, hypertension and diabetes (Mourad et al, 2012). Unfortunately, it is unknown if this refers to cardiac- or non-cardiac chest pain (Mourd et al, 2012, Ono \&Falcao, 2016).

Silent myocardial infarction has a reported incidence ranging from $22 \%$ to $60 \%$ of the total incidence of myocardial infarctions, and is related with poor prognosis (Pride et al, 2013). A misunderstanding of warning signs and symptoms of myocardial infarction and ischemic cardiac pain may be the consequence of different types of cardiac chest pain experienced by women. Besides, the high level Good Girl group of women scored notably higher in "refrain medical consultation despite the need" than the low level Good Girl group. 
It appears that women do not permanently identify the threat of CHD and delay seeking care for signs of acute myocardial infarction, even if there is a significant family history of the disease (O'Keefw-McCarthy S, 2009). This also corresponds with findings in the interview study; the women delayed seeking care and did not recognize the symptoms as they suffered an MI. The high level Good Girl group more often reported symptoms of anxiety than women in the low level Good Girl group, although no major differences in diagnosed anxiety were found.

Anxiety has been confirmed to be a prognosticator of premature all-cause mortality and cardiovascular death in middle-aged women, even after adjustment for depression and standard CVD risk factors. A thinkable biological mechanism by which anxiety in middle-aged women could be associated to CVD is through high norepinephrine and cortisol levels (Nabi et al, 2010).

Significant differences were seen between the two groups in relation to psychological distress. Women in the high level Good Girl group reported more occurrence of stress, living under constant stress, feeling unhappy and depressed, lost sleep because of worrying, low self-confidence and feeling worthless. Individuals with maladaptive behavior in a stressful situation and low scores on extraversion should be classified as vulnerable to the harmful effects of stress and thereby exposed to a strengthened risk of a more severe infarction (André-Petersson et al, 2011).

The suggested personality trait "being a Good Girl" may have associations with the Type D personality. Therefore, it could also be related with depression, anxiety and stress, and thereby be pathophysiological associated with CVD morbidity (Denollet et al, 2010, Schlyter et al, 2011). Individuals with chronic stress and/or depression have an imbalance in the autonomic function, which in turn affects hemostatic and inflammatory processes, myocardial perfusion and the endothelial function (Chandola et al, 2008).

The concept "Good Girl" personality trait was primarily defined by others (Wennerholm, 2014, Blom \& Johnson, 2011, Blom, 2012), in connection with chronic fatigue diseases and the burnout syndrome (Schaufeli \& Buunk, 2003, Apples \& Mulder, 1998). Those affected are characterized by low self-esteem, high demands on themselves, and adapting easily to the environment. They push themselves too hard and have no limits because of a strong need to always be accepted. They need to perform at their best to compensate for their low self-esteem, meaning that they have a performance-based confidence. These women have a contingent self-esteem and place high demands on themselves. In combination with depression, anxiety and sleep disturbances, this may ultimately lead to burnout (Wennerholm, 2014, Blom \& Johnson, 2011, Blom, 2012, Schaufeli \& Buunk, 2003, Apples \& Schouten, 1991).

Women in the high level Good Girl group reported significantly more tiredness and "consider themselves to be pedantic". Burnout can also be called "the superachiever sickness", and occurs when individuals strongly believe in their idealized images of themselves as inexhaustible, charismatic and super-competent people. 
As a result of this behavior, they completely lose touch with their fallible, "real" selves. A typical burn out personality trait is desperately trying to maintain idealized self-image, which additionally drains all emotional resources. With this reasoning, it may be thought that there are common features between "consider themselves to be pedantic" and to be a super-achiever, who believe in their ideal images of a super competent person (Schaufeli \& Buunk, 2003).

Women perceive more work stress than men. However, there are stronger connections between work stressors and burnout among men, whereas in women, there are stronger connections between performance-based self-esteem and burnout, (Blom, 2012). These individual characteristics can be a risk factor for CVD as the link to anxiety and depression and the relationship to the pathophysiological process strengthens the risk for CVD (Steptoe \& Kivimäki, 2013).

\section{Study limitation and methodological consideration}

\section{The health care register (HCR)}

Computerized data files of all inhabitants in Sweden, The Health Care Register (HCR), are linked by birth date and gender. The same personal code is used in the HCR for all visits and diagnoses. An individual can thus be followed retrospectively or prospectively through the health care system. All health care levels, primary care, outpatient hospital care, and/or inpatient hospital care, as well as in which health care institution the patient was diagnosed. A general limitation is that misclassifications in register data do occur, including cases that are not recorded because they are overlooked or given incorrect clinical codes. There is also potential for some referral bias. However, according to The National Board of Health and Welfare, analysis of the quality and content of the Swedish Hospital Discharge Register implies up to $98 \%$ coverage of main diagnostic codes of inpatient care (Wirehn et al, 2007). Validation of the HCR and other similar administrative health care data registers has presented high specificity in registers covering all types of health care (Wilchesky et al, 2004, Szeto et al, 2002, Humphries et al, 2000). Therefore, it can be assumed that HCR data show high specificity.

\section{Twin cities}

When comparing geographically close cities, one could always expect that migration between them. However, it unlikely that this population migration is health related, and thus does not present a health selection bias. The comparisons of diagnoses between the two cities were stratified for age, but not age-adjusted. Age is a strong predictor of cardiovascular disease and the age strata might appear broad (45-64; 65-79 years). Still, the age-distribution in the two cities is fairly even, allowing only a minor risk of a potential confounding by age. 


\section{Qualitative methods}

Even though an inductive method was used, impacts of established knowledge cannot be ruled out. Hence, the interview guide used for the qualitative interviews was not developed in isolation, but against the background of prior research in this field. General recall-bias phenomenon could have affected the women's narratives or women who wanted to make changes to their life stories. However, the overall impression of the interviews was that the women were credible, trustworthy and reliable. The fact that the interviews were carried out in the women's own homes was believed to have had a positive effect. Although the interview was extensive and lasted $60-90$ minutes, there were no signs that the respondents found it meaningless or boring. On the contrary, all women participated with great generosity. Over one third of all women who had suffered an MI in the defined region were interviewed during a two-year period, reflecting that MI is quite an unusual event among younger and middle-aged women (Idris et al, 2011). Two experienced researchers conducted all the interviews. These were interpreted and coded by four researcher's altogether, which strengthens the quality. In addition, compliance was $100 \%$; all the contacted women wanted to participate and no dropouts occurred. In the view of qualitative studies, it is fundamentally inductive, to attain generalizable results is not primarily, rather to gain new knowledge and hypothesis. The transferability, i.e., to what extent these results could be transferred to other context or settings, is mainly the authors' responsibility.

The research process should be transparent so that other researchers have the possibility to do the generalizing.

\section{Cross-sectional design/study:}

The cross-sectional study design has one limitation. Because the exposure and outcome are concurrently measured, there is no evidence of a causal association between exposure and outcome. It is not possible to establish a true cause and effect relationship without longitudinal data. Furthermore, there was a problem reaching those in a population most seriously affected, such as the unhealthiest people and those with language difficulties. Regarding the comparison between Scotland and Sweden, this is likely a problem in both countries.

In the QWIN-study (Paper III), the respondents were given different options of how to respond to the survey as an effort to overcome such problems. In the QWIN-study there was a response rate of $58 \%$, which nowadays is acceptable (Paper III). It is not unusual with a response rate below 50\%, as response rates in scientific surveys have tended to decline over time (Nilsson, 2009).

\section{Good Girl index:}

The questions essential for the concept "being a Good Girl" have been previously validated. The factor analysis that was carried out was coherent enough to make the three single questions into an index. Based on three specific questions covering the phenomenon of "being a Good Girl", a factor component score was created. These questions were primarily formulated from acquired knowledge in our previous qualitative study of middle-aged women who had suffered myocardial infarction (Wennerholm et al, 2014). 
Our purpose was to measure this personality trait in a larger group of middleaged women through a quantitative survey (Paper III). It is possible that only parts of the personality trait were covered by the "being a Good Girl"-concept. We still seem to have identified a group of women who presented the same symptoms and inconvenience as in the interview study, which strengthens our Good Girl index.

\section{Validated instruments}

Validated instruments and questions have been used in these studies, which is a strength. We also had access to diagnoses set by doctors from a Health Care Register that complemented the self-reported data (Wirhen, 2007).

Most of the questions in the Swedish questionnaire were replicated from the Scottish Health Survey questionnaire, which should improve the comparison of data between the two countries. The Scottish data were only based on self-reported diagnoses, for the Swedish data we also had access to diagnoses set by doctors. This may, by some means, impair the comparability of the estimates.

However, the self-reported Scottish diagnoses tend to have been underestimates of the true prevalence of conditions, so the variation observed between the two countries is likely to have been under-, rather than over-estimated. The absolute number of affected women in the Swedish data must be considered in the comparisons, as the incidence of cardiovascular diagnosis in general is relatively low among middle-aged women.

\section{General conclusion}

From an upstream perspective, we found profound differences in cardiovascular morbidity and mortality between two close but socially different environments, the Twin cities. These disparities also seem to be stable over time. The comparison between Scotland and Sweden, also an upstream perspective, clearly displayed that Scottish middle-aged women are - relative to Swedish women - particularly affected by a worse profile of CVD risks, even after adjustment for education. The most likely reason for these different pictures of health in each country seems to have cultural, historical, economic and political origins. From a downstream perspective and through qualitative interviews with middle-aged women it was found that these women were affected by a variety of psychosocial factors. The psychosocial phenomenon to strive "to be a good girl", a personality trait to which these women have been shaped throughout their lives, represented a cluster of psychosocial risk factors. Further investigation of the personality trait "being a Good Girl" also from a downstream perspective revealed that women with a high level of the personality trait labeled "being a Good Girl" have more psychosocial risk factors and more commonly report chest pain without seeking medical care. However, no increased prevalence of cardiovascular diseases was found among women in the high level Good Girl group. The high level Good Girl group might be a group of women with a potentially increased risk of developing cardiovascular symptoms and diseases when they grow older and should be considered clinically. 


\section{Implications for further research}

Health behaviors and lifestyles seem to remain in both social environments, casting a shadow of higher risk of cardiovascular disease in the population of the bluecollar city. This has strong public health implications, with an upstream approach to initiate a long-term community intervention program in the blue collar city.

There are programs that have shown that community-based interventions truly decrease the risk of cardiovascular disease in a community, using an upstream perspective and working in collaborations involving politicians, health care providers, primary care and the public. The results are most reassuring: a steady reduction of cardiovascular morbidity and mortality in these populations has been documented (Lindholm, 1996, Weinehall, 1997)

There is plenty of room to improve the health of Scottish women in this age group, for example, through improved recognition and control of traditional "Framingham" risk factors for CVD. Regulatory actions targeting the price and supply of alcohol and unhealthy food, and policies designed to tackle the structural causes of health inequalities might be some avenues to try. In future research, it could be feasible to use an anthropological design to investigate how different cultures, with their specific history, economy and political environments, affect people's ways of thinking and acting. It is a well-known fact that unequal societies are harmful to cardiovascular health. An important key point is therefore to work against unequal societies to promote cardiovascular health with an upstream perspective. Starting early, in childhood and adolescence, should be emphasized. The likelihood of affecting these individuals is greater, the chances for succeeding with the intervention increases, and thus it will be more cost effective.

The importance of the psychosocial phenomenon to strive "to be a good girl" is a hypothesis that needs to be further investigated and identified in future studies of cardiovascular risks in women. This emphasizes the value of psychosocial risk factors in the assessment of middle-aged women's risk profile for MI. In clinical practice, the assessment of the individual risk for myocardial infarction among middle-aged women, not least potential psychosocial factors, might also need to be considered.

The middle-aged women in the high level Good Girl group might be a group with a possibly increased risk of developing cardiovascular symptoms and diseases when they grow older. Whether this personality trait occurs among men, i.e., "good men", might be a topic for future research.

Stress is a key component for psychosocial risk factors for CVD. Measurement of long-term stress exposure through cortisol in hair could demonstrate the importance of stress as a psychosocial risk factor for CVD. 


\section{POPULÄRVETENSKAPLIG SAMMANFATTNING}

Vikten av att studera människors olika livsvillkor och sociala miljö för att förstå en befolknings hälsa är känt sedan länge inom social medicin, folkhälsomedicin. Den sociala hierarkin i ett samhälle och individens plats i den hierarkin är av betydelse för hälsan. Trots stor nedgång i sjuklighet och dödlighet i hjärt-kärlsjukdom de senaste decennierna är fortfarande hjärt-kärlsjukdom den största orsaken till sjukdom och för tidig död för båda könen i alla Europeiska länder. Ohälsobördan från hjärt-kärlsjuklighet är betydande och en viktig orsak för att satsa på förebyggande åtgärder.

Syftet med denna avhandling var att öka kunskapen kring faktorer i den sociala miljön och individuella faktorer som kan förklara varför vissa kvinnor i yrkesverksam ålder drabbas av hjärt-kärlsjukdom. Fortsättningsvis att analysera riskfaktorer för hjärt-kärlsjukdom och förekomst av hjärt-kärlsjukdom bland medelålders kvinnor i olika sociala miljöer.

Delstudierna i den här avhandlingen bygger till stor del på populationen inom Twin cities, vilket består av två jämnstora städer som ligger nära varandra och tillhör samman sjukvårdsregion. Med anledning av städernas olika socialhistoria kan de benämnas som,"blue collar" city, en stad med övervägande arbetare och "white collar" city, en stad med övervägande tjänstemän och personer med högre utbildning. Kompletterande uppgifter avseende diagnoser gällande vår studiepopulation har erhållits från ett lokalt register där diagnoser och vårdbesök registrerats.

Den första delstudien visade att det förelåg skillnader i sjuklighet och dödlighet i hjärt-kärlsjukdom mellan de olika städerna, arbetarstaden hade mer sjuklighet och dödlighet i hjärt-kärlsjukdom än tjänstemannastaden. Intervjuer gjorda med kvinnor 40-65 år som drabbats av hjärtinfarkt visade att dessa kvinnor var tyngda av en hög grad av psykosociala riskfaktorer men även klassiska riskfaktorer. Ett personlighetsdrag som hittades bland dessa kvinnor var "Duktig flicka”. Detta personlighetsdrag studerade vi vidare i Twin city via en enkätstudie. Här visade sig att dessa kvinnor med en hög nivå av personlighetsdraget

"'Duktig flicka" hade mer psykosociala och klassiska riskfaktorer för hjärt-kärlsjukdom. Slutligen genomför vi en jämförande studie mellan Sverige och Skottland avseende medelålders kvinnor och risker och sjuklighet i hjärt-kärlsjukdom. Studien uppvisar stora skillnader i både klassiska och psykosociala riskfaktorer för hjärt-kärlsjukdom samt även ökad sjuklighet, företrädesvis i hjärtinfarkt och kärlkramp.

De viktigaste fynden i den här avhandlingen är att olika sociala miljöer har betydelse för risker för hjärt-kärlsjukdom och även sjuklighet och dödlighet i hjärtkärlsjukdom. Att medelålders kvinnor som drabbas av hjärtinfarkt i denna avhandling fanns vara "Duktiga flickor" och tyngda av främst psykosociala riskfaktorer för hjärt-kärlsjukdom, vilka kan antas ha en ökad risk för att insjukna i hjärt-kärlsjukdom när de blir äldre. 


\section{ACKNOWLEDGEMENTS}

This thesis would never have come to existence without the collaboration and support of a large number of people to whom I would like to express my warmest gratitude. In particular, I would like to thank:

My supervisor Tomas Faresjö, for your faithful support and constant inspiration throughout this roller-coaster ride or bumper cars. Always cool, down to earth and understanding, and for your ability to make me do things I am afraid of. For me, you are a true humanist, always with a sense of humor and sharpness and never standing on high horses.

Co-supervisor AnnaKarin Johansson, thank you for not thinking like me, I also appreciate your sharpness and skills. Staffan Nilsson for giving me medical advice in my studies and for your quantitative way of thinking, (and for all the money), Tiny Jaarsma I am grateful that you have taken time to supervise me and share your great knowledge and experience.

Professor John Frank, The Scottish Collaboration of Public Health Research (SCPHRP), Edinburgh University, Scotland, for letting me come and stay with your team for a month in June 2014. Thank you for your supervision and positive interest in my research, and sharing the excellent Scottish Health Survey database with me.

Catherine Bromley, the person with the most experience of the Scottish Health Survey at SCPHRP. Thank you for your guidance and for sharing your knowledge with me.

Other colleges at SCPHRP, Edinburgh University, Ruth Jeppson, Tony Robertson, and Renee Ingram, office manager.

The researchers in the TWINCITIES Research Group for support and inspiring seminars and discussions.

The 16 interviewed women who generously shared their life experiences and professor Marja-Liisa Honkasalo, Michaela Jern and Lena Trell who supported the qualitative analysis of the collected data.

All the women participating in the QWIN-study, answering a questionnaire.

My managers at the Division of nursing, Sussanne Börjeson and Katarina Berg, for giving me the financial opportunity every semester and encouraged me to move on.

Sophie Stoppert-Gustafsson, for helping me calculate the grants, and our good chats.

Kristoffer Arestedt, for excellent help with statistics in the QWIN-study. 
Sofia McGarvey for helping me, always, with language review of my texts. I do not understand how you manage?

My dear friend Marie Danielsson, thank you for your faithful support and friendship.

Helen Marklund, thank you for letting me and my family enjoy your lovely Anderstorp. You are always supportive and positive.

Elisabeth Larsen-Cederström, thank you for always believing in me and supporting me in everything. You have taught me a lot, especially how to be a good leader.

Ing-Marie Byström, what would I do without you? Always there helping out, patient and calm.

Colleagues and doctoral students at the Nursing department, Linköping University, Jenny Drott, Lena Näsström (not working with us anymore) Carina Hjelm, Sara Bergstrand, Helena Johansson, Rikard Wärdig och Birgitta Samuelsson.

Colleauges and doctoral students at Community medicine, Linköping University; first Carl-Johan Östgren as a substance liable in General Medicine where I was enrolled as a PhD-student.

Susanna Strömberg, thank you for helping me with the QWIN-database and our nice chats.

I also want to mention Mats Foldevi, Karin Rådholm and Kristian Gessing.

The National Research School in General Practice, a fantastic time. The best scientific courses, seminars and teachers you can imagine. Always full with energy after our meetings.

And last, but not least, my husband Magnus and our children Emil and Johanna whom I love dearly, for giving me the opportunity to only think about one thing, the Thesis!

The Church hosts and other friends in Vidingsjö kyrkby, Linköping, you always listen to my worries and whine about me writing a Thesis.

\section{GRANTS}

The studies where supported by the the Department of Nursing Science, Linköping University, grants from Linköping University and Region Östergötland "from student to docent" and Clinic ALF grants, Riksföreningen HjärtLung, Stockholm, Sweden, Research and Research Education Board (FUN), Linköping University, Predoc at Edinburgh University sponsored by National Research School in General Practice, Sweden. 


\section{REFERENCES}

Alboni, P., Amadei, A., Scarfó, S., Bettiol, K., Ippolito, F., Baggioni, G.(2003) In industrial nations, a low socioeconomic status represents an independent predictor of mortality in patients with acute myocardial infarction. Italian Heart Journal, 4(8) ss. 551-558.

Albus, C., Jordan, J. \& Herrmann-Lingen, C. (2004) Screening for Psychosocial Risk Factors in Patients with Coronary Heart Disease - Recommendations for Clinical Practice. European Journal of Preventive Cardiology, 11, ss. 75-79.

Anand, S.S., Islam, S., Rosengren, A., Franzosi, M.G., Steyn, K., Yusufali, A.H. \& Keltai, M. (2008). Risk factors for myocardial infarction in women and men: insights from the INTERHEART study. European Heart Journal, 29, ss. 932-940.

Andersen, I., Diderichsen, F., Kornerup, H., Prescott, E. \& Rod, N.H. (2011) Major life events and the risk of ischaemic heart disease: does accumulation increase the risk? International Journal of Epidemiology, 40(4), ss. 904-913.

André-Petersson,L., Hagberg, B., Hedblad, B., Janzon, L. \& Steen, G. (1999) Incidence of cardiac events in hypertensive men related to adaptive behavior and stressful encounters. International Journal Behavioral Medicine. 6(4), ss. 331355 .

André-Petersson, L., Schlyter, M., Engström, G., Tydén, P. \& Hedblad, B. (2011). Behavior in a stressful situation, personality factors, and disease severity in patients with acute myocardial infarction: baseline findings from the prospective cohort study SECAMI (The Secondary Prevention and Compliance following Acute Myocardial Infarction-study). BMC Cardiovascular Disorders, 11, ss. 45.

Apples, A. \& Mulder, P. (1998). Fatigue and heart disease. The association between vital exhaustion and past present and future coronary heart disease. Journal Psychosomatic Research, 33, ss. 727-738.

Apples, A. \& Schouten, E. (1991). Burnout as a risk factor for coronary heart disease. Behavioral Medicine, 17(2), ss. 53-59.

Arnberg, F.K., Michel, P.-O., \& Johannesson, K.B. (2014) Properties of Swedish Posttraumatic Stress Measures after a Disaster, Journal of Anxiety Disorders.

Banzer, J.A., Maguire, T.E., Kennedy, C.M., O’Malley, C.J. \& Balady, G.J. (2004) Results of cardiac rehabilitation in patients with diabetes mellitus. American Journal of Cardiology. 93(1), ss.81-84. 
Barth, J., Schumacher, M. \& Merrmann.Lingen, C. (2004) Depression as a risk factor for mortality in patients with coronary heart disease: a meta-analysis. Psychosomatic Medicine, 66(6), ss.802-13.

Beaglehole, R., Bonita, R., Kjellström, T. (2010) Grundläggande epidemiologi. Lund: Studentlitteratur.

Bertuccio,P., Levi, F., Lucchini, F., Chatenoud, L., Bosetti, C., Negri, E., La Vecchia, C. (2016) Coronary heart disease and cerebrovascular disease mortality in young adults: recent trends in Europe. European Journal of Cardiovascular Prevention \& Rehabilitation,18(4).

Blom, V. (2011) Striving for Self-Esteem-Conceptualization and Role in Burnout. Diss, Stockholm: Stockholm University.

Blom, V., Johnson, M. (2011) Physiological and Behavioral Reactivity when One's Self-Worthis Staked on Competence. Individual Differences Research, 9(3) ss. 138-152.

Blom, V. (2012) Contingent self-esteem, stressors and burnout in working women and men. Work, 43, ss. 123-131.

Bloomfield K, Stockwell T, Gmel G, Rehn N. (2003) International Comparisons of Alcohol Consumption. National Institute for Alcohol Abuse and Alcoholism, United Kingdom. https://pubs.niaaa.nih.gov/publications/arh27-1/95109.htm[2017-05-01]

Boehm, J.K., Chen, Y., Williams, D.R., Ryff, C.D., Kubansky, L.D. (2016) Subjective well-being and cardiometabolic health: An 8-11 year study of midlife adults. Journal Psychosomatic Research, 85, ss. 1-8.

Bogg,T., Brent, W,R. (2013) The Case for Conscientiousness: Evidence and Implications for a Personality Trait Marker of Health and Longevity. Annals of Behavior Medicine, 45, ss. 278-288.

Bosma, H., Marmot, M.G., Hemingway, H., Nicholson, A.C., Brunner, E., Stansfeld, S.A. (1997) Low job control and risk of coronary heart disease in Whitehall II (prospective cohort) study. British Medical Journal, 314(7080), ss. 558-65.

Chaix, B., Bean, K., Leal, C., Thomas, F., Havard, S., Evans, D., et al (2010) Individual /neighbourhood social factors and blood pressure in the Record cohort study: which risk factors explain the associations? Hypertension, 55, ss. 769-775.

Chandola, T., Britton, A., Brunner, E., Hemingway, H., Malik, M., Kumari, M. et al (2008) Work stress and coronary heart disease: what are the mechanisms? European Heart Journal, 29, ss. 640-648.

Christakis, N., Fowler, J. (2007) The spread of obesity in a large social network over 32 years. New England Journal of Medicine, 357, ss. 370-378. 
Clark, A.S., Des Meules, M., Lou, W., Duncan, A.S., Wielgosz, A. (2009) Socioeconomic status and cardiovascular disease: risk and implication for care. Nature Reviews Cardiology. Nov, 6(11), ss. 712-22.

Connor-Smith, J.K., Flachsbart, C. (2009) Relations between personality and coping: A meta analysis. Journal of Personality and Social Psychology, 93, ss. $1080-1107$.

Coventry, L., Finn, J., Bremner, A. (2011) Sex differences in symptom presentation in acute myocardial infarction: A systematic review and meta-analys. Heart \& Lung, ss. 477-491

Cramer, D. (1991) Type A behavior pattern, extraversion, neuroticism and psychological distress. British Journal of Medical Psychology, 64, ss. 73-83.

Cummins, S., Curtis, S., Diez-Roux, A.V., MacIntyre, S. (2007) Understanding and representing "place" in health research: a relational approach. Social Science of Medicine, 65, ss. 1825-1838.

Deary, I.J., Weiss, A., Batty, G.D. (2010) Intelligence and personality as predictors of illness and death: How researchers in differential psychology and chronic disease epidemiology are collaborating to understand and address health inequalities. Psychological Science in Public Interest, 11, ss. 53-79.

Denollet, J. (2000) Type D personality. A potential risk factor refined. Journal of Psychosomatic Research. 49(4), ss. 255-266. DOI:10.1016/So0223999(00)00177-X.

Denollet, J., Schiffer, A.A., Spek, V. (2010) A general propensity to psychological distress affects cardiovascular outcomes: evidence from research on the type D (distressed) personality profile. Circulation: Cardiovascular Quality Outcomes, 3, ss. 546-557.

De Smith, D., De Bacquer, D., De Sutter, J., Dallongeville, J., Gevaert, S., De Backer, G. et al. (2016)The gender gap in risk factor control: Effects of age education on the control of cardiovascular risk factors in male and female coronary patients. The EURASPIRE IV study by the European Society of Cardiology. International Journal of Cardiology, 209, ss. 284-290.

Diderichsen, F. (2002) Hälsan går att påverka. Stockholm: Karolinska Institutet.

Diez-Roux, A.V., Nieto, F.J., Muntaner, C., Tyroler, H.A., Comstock, G.W., Shahar, E. et al. (1997) Neighborhood environments and coronary heart disease, a multilevel analysis. American Journal of Epidemiology, 146, ss. 48-63.

Dorner, T., Fodor, J.G., Allichhammer, D., Kiefer, I., Lawrence, K., DÁngelo, M.S., et al. (2006) A heart for Vienna - the prevention program for the big city. Blue-collar workers as a special target group. Wien Medizinische Wochenschrift, 156, ss. 552-557. 
Edling, C. \& Liljeros, F. (red) (2010). Ett delat samhälle: makt, intersektionalitet och social skiktning. Malmö: Liber.

Fox, C.S., Pencina, M.J., Wilson, P.W., Paynter, N.P,, Vasan RS, D’Agostino,R.B, Sr. Lifetime risk of cardiovascular disease among individuals with and without diabetes stratified by obesity status in the Framingham heart study. Diabetes Care, 31(8),ss.1582-1584.

Gerber, Y., Weston, S.A., Killian, J.M., Therneau, T.M., Jacobsen, S.J., Roger, V.L. (2008) Neighborhood income and individual education: effect on survival after myocardial infarction. Mayo Clinical Proceedings, 83, ss. 663-669.

Gerber, Y., Benyamini, Y., Goldbourt, U., Drory, Y. (2010) Israel Study Group on First Acute Myocardial Infarction. Neighborhood socioeconomic context and long-term survival after myocardial infarction. Circulation, 121, ss. 375-383.

Gisselmann, M., Hemström, Ö., Toivanen, S.(2012) Kön, genus och skillnader i hälsa. I Rostila, M. \& Toivanen, S. Den orättvisa hälsan - om socioekonomiska skillnader i hälsa och livslängd, Stockholm: Liber, ss. 62-79.

Golderberg, D., Williams, P. (1988) A user's guide to the General Health questionnaire. UK: Windsor, NFER-Nelson.

Goldberg, D.P., Gater, R., Sartorious, N., Ustun, T.B., Piccinelli, M., Gureje, O. et al. (1997) The validity of two versions of GHQ in the WHO study of mental illness in general health care. Psychological Medicine, 27, ss. 191-197.

Gonzalez, A., Jenkins, J.M., Steiner, M., Flemming, A.S. (2009) The relation between early life adversity, cortisol awakening response and diurnal salivary cortisol levels in postpartum women. Psychoneuroendocrinology, 34(1), ss. 76-86.

Graneheim, U.H.,Lundman, B. (2004) Qualitative Content Analysis in Nursing Research: Concepts, Procedures and Measures to Achieve Trustworthiness. $\begin{array}{lllll}\text { Nurse } \quad \text { Education } & \text { Today, } & \text { s. } & \text { 105-112. }\end{array}$ http://dx.doi.org/10.1016/j.nedt.2003.10.001

Grodzinsky, E., Hallert, C., Faresjö, T., Bergfors, E., Faresjö, A.O. (2012) Could gastrointestinal disorders differ in two close but divergent social environments? International Journal of Health Geographics, 11(5).

Guest, G., Bunce, A., Johnson, L. (2006) How Many Interviews Are Enough? An Experiment with Data Saturation and Variability. Field Methods, 18, ss. 59-82.

Gulliksson, M., Wedel, H., Köster, M., Svärdsudd, K. (2009) Hazard function and secular trends in the risk of recurrent acute myocardial infarction: 30 years of follow-up of more than 775000 incidents. Circulation: Cardiovascular Quality Outcomes, 2, ss. 178-185. 
National Institute of Public Health A (2011;09). Health on equal terms. Purpose and background to the issues of the National Public Health questionnaire. https://snd.gu.se/en/catalogue/series/national-public-health-survey-healthon-equal-terms. [2017-03-24].

Hahn, R. A. (1997) The nocebo phenomenon: concept, evidence, and influence on public health. Preventive Medicine, 26, ss. 607-611.

Hardy, G. E., Shapiro, D. A., Haynes, C. E., \& Rick, J. E. (1999). Validation of the General Health Questionnaire-12: Using a sample of employees from England's health care services. Psychological Assessment 11(2), ss.159.

Honkasalo, M.-L. (2009a) Grips and Ties - Agency, Uncertainty, and the Problem of Suffering in North Karelia. Medical Anthropology Quarterly, 23, ss. 5169.

Faresjö, T., Söderqvist, J., Ludvigsson, J., Grodzinsky, E., Nilsson, H. (2007) Twin cities with big social differences when it comes to public health. A sociomedical "experiment" introduced in Norrkoping and Linkoping. Läkartidningen, Jun 4-11, 104(23), ss. 1788-1790.

Faresjö, T., Rahmqvist, M. (2010) Educational level is a crucial factor for good perceived health in the local community. Scandinavian Journal of Public Health, 38 , ss. $605-610$.

Forsman, L., Johnson, M. (1996) Dimensionality and Validity of Two Scales Measuring Different Aspects of Self-Esteem. Scandinavian Journal of Psychology, 37, ss. 1-15. http://dx.doi.org/10.1111/j.1467-9450.1996.tboo635.x

Frank, J., Bromley, C., Doi, L., Estrade, M., Jepson, R., McAteer, J. et al. (2015) Seven key investments for health equity across the lifecourse: Scotland versus the rest of the UK. Social Science \& Medicine,140, ss.136-146.

Hahn, R. A. (1997) The nocebo phenomenon: concept, evidence, and influence on public health. Preventive Medicine, 26, ss. 607-611.

Hallman, T., Burell, G., Setterlind, S., Odén, A., Lisspers, J. (2001) Psychosocial risk factors for coronary heart disease, their importance compared with other risk factors and gender differences in sensitivity. Journal of Cardiovascular Risk, 8(1), ss. 39-49.

Helman, C.G. (2007) Health and Illness. Oxford: University Press.

Holmberg, S., Weibull, L. (red.) (2009) The national SOM Study. Göteborg: Nordic light.

Humphries, K.H., Rankin, J.M., Carere, R.G., Buller, C.E., Kiely, F.M., Spinelli, J.J. (2000) Co-morbidity data in outcomes research: Are clinical data derived from administrative databases a reliable alternative to chart review? Journal of Clinical Epidemiology, 53, ss. 343-349. 
Idris, N., Aznal, SS., Chin, SP., Ahmad, W.A., Rosman, A., Jeyaindran, S. (2011) Acute Coronary Syndrome in Women of Reproductive Age. International Journal of Women's Health, 3, ss. 375- 380.

Jenkins, C.D., Rosenman, R.H., Zyzanski, S.J. (1974) Prediction of clinical coronary heart disease by test of the coronary-prone behavior pattern. New England Journal of Medicine, 290, ss. 1271-1275.

Johnson, J.V., Stewart, W., Hall, E.M., Fredlund, P., Theorell, T. (1996) Longterm psychosocial work environment and cardiovascular mortality among Swedish men. American Journal of Public Health, 86(3), ss. 324-331.

Johnson, M., Forsman, L. (1995) Competence Strivings and Self-Esteem: An Experimental Study. Personality and Individual Differences, 19, ss. 417-430. http://dx.doi.org/10.1016/0191-8869(95)ooo81-G

Kabir, Z., Bennett, K., Shelly, E., Unal, B., Critchley, J.A., Capewell, S. (2007) Comparing primary prevention with secondary prevention to explain decreasing coronary heart disease death rates in Ireland. 1985-2000. BMC Public Health, 7, Ss. 117 .

Kannel, W.B., Dawber, T.R., Kagan, A., Revotskie, N., Stokes, J. (1961) Factors of risk in the development of coronary heart disease: six year follow-up experience. The Framingham Study. Annals International Medicine, 55, ss. 33-50.

Kaplan, G.A., Keil, J.E. (1993) Socioeconomic factors and cardiovascular disease: a review of the literature. Circulation, 88(4 Pt 1), ss. 1973-98.

Kaplan, G.A. (2004) What's Wrong with Social Epidemiology, and How Can We Make It Better? Epidemiologic Reviews, 26, ss. 124-135.

Karlén, J., Ludvigsson, J., Frostell, A., Theodorsson, E., Faresjö, T. (2011) Cortisol in hair measured in young adults - a biomarker of major life stresors? BMC Clinical Pathology, 11, 12.

Keys, A., Aravanis, C., Blackburn, H., Van Buchem, F.S., Buzina, R., Djordjevic, B.S. et al. (1972) Probability of middle-aged men developing coronary heart disease in five years. Circulation, 45(4), ss. 815-828.

Kivimäki, M., Virtanen, M., Elovainio, M., Kouvonen, A., Väänänen, A., Vahtera, J. (2006) Work stress in the etiology of coronary heart disease - a meta-analysis. Scandinavian Journal of Work, Environment \& Health, 32(6), ss. 431-442.

Koivula, N., Hassmén, P., Fallby, J. (2002) Self-Esteem and Perfectionism in Elite Athletes: Effects on Competi- tive Anxiety and Self-Confidence. Personality and Individual Differences, 32, ss. 865-875. http://dx.doi.org/10.1016/So1918869(01)00092-7 
Kop, W.J. (1997) Acute and chronic psychological risk factors for coronary syndromes: Moderating effects of coronary artery disease severity. Journal of Psychosomatic Research, 43(2), ss. 167-181.

Kuper, H., Marmot, M., Hemingway, H. (2002) Systematic review of prospective cohort studies of psychosocial factors in the etiology and prognosis of coronary heart disease. Seminars in Vascular Medicine, 2, ss. 267-314.

Kvale, S., Brinkmann, S. (2009) Den kvalitativa forskningsintervjun; andra upplagan. Lund: Studentlitteratur.

Kyndaron, R., Thomas, E., Andruseik, D., Aufderheide, S., Callaway, C., Pepe, P., et al. (2011) Socioeconomic status and incidence of sudden death of cardiac arrest. Canadian Medical Association Journal, October 18, 183(15).

Kölegård-Stjärne, M., Didrichsen, F., Reuterwall, C., Hallqvist, J. (2002) Socioeconomic context in area of living and risk of myocardial infarction: results from Stockholm Heart Epidemiology Program (SHEEP). Journal of Epidemiological Community Health, 56, ss. 29-35.

Kölegård-Stjärne, M.(2005) A matter of context. Social inequalities of myocardial infarction. Diss. Stockholm: Stockholms Universitet/Karolinska Institutet.

Lawler, K.A., Younger, J.W., Piferi, R.L., Billington, E., Jobe, R., Edmondson, K., Jones, W.H. (2003) A change of heart: cardiovascular correlates of forgiveness in response to interpersonal conflict. Journal of Behavior Medicine, 26(5), ss. 373-393.

Levi L, Bartley M, Marmot M, Karasek R, Theorell T, Siegrist J. et al. (2000) Stressors at the workplace: theoretical models. Occupational Medicine, JanMars;15(1), ss. 69-106.

Lindholm, L. (1996) Health economic evaluation of community-based cardiovascular disease prevention: some theoretical aspects and empirical results. Diss. Umeå: Umeå University.

Low, C.A., Thurston, R.C., Matthews, K.A. (2010) Psychosocial factors in the development of heart disease in women: current research and future direction. Psychosomatic Medicine, 72(9), ss. 843-854.

Lunch, J.W., Kapland, G.A., Cohen, R.D., Tuomilehto, J., Salonen, J.T. (1996) Do cardiovascular risk factors explain the relation between socioeconomic status, risk of al-cause mortality, cardiovascular mortality, and acute myocardial infarction? American Journal of Epidemiology, 144, ss. 934-942.

Lundberg, O., Manderbacka, K., (1996) Assessing reliability of a measure of selfrated health. Scandinavian Journal of Social Medicine, 24, ss. 218-24 
Lundberg, O., Åberg Yngwe, M., Kölegård Stjärne, M., Björk, L., Fritzell, J. (2008) The Nordic Experience: Welfare States and Public Health (NEWS). Health Equity Studies No 12 Centre for Health Equity Studies (CHESS), Stockholm: Stockholms Universitet/Karolinska Institutet.

Lundgren, O., Garvin, P., Jonasson, L., Andersson, G., Kristenson, M. (2015) Psychological Resources are associated with reduced incidence of coronary heart disease. An 8-year follow-up of a community-based Swedish sample. International Journal of Behavior Medicine, 22, ss. 77-84.

Maas, A.H., van der Schouw, Y.T., Regitz-Zagrosek, V., Swahn, E. Appleman, Y.E., Pasterkamp, G. (2011) Red alert for women's heart: the urgent need for more research and knowledge on cardiovascular disease in women: proceedings of the workshop held in Brussels on gender differences in cardiovascular disease, 9 September 2010. European Heart Journal, 32(11), ss. 1362-1368.

Macintyre, S., Maciver, S., Sooman, A. (1993) Area, class and health, should we focus on places or people? Journal of Social Policy, 22, ss. 213-234.

MacIntyre S., Ellaway, A. (2000) Ecological Approaches. Rediscovering the Role of the Physical and Social Environment. I Berkman L, Kawachi I (red.), Social Epidemiology. UK:Academic Press

Macintyre, S., Ellaway, A., Cummins, S. (2002) Place effects on health, how can we conceptualise, operationalise and measure them? Social Science \& Medicine, 55, ss.125-139.

Marmot, M.G., Adelstein, A.M., Robinson, N., Rose, G.A. (1978) Changing social class distribution of heart disease. British Medical Journal, ii, ss. 109-112.

Marmot, M., \& Wilkinson, R. (red.) (2006) Social determinants of health.

Oxford: Oxford University Press.

Marmot, M. (2007) Achieving health equity: from root causes to fair outcomes. Lancet, 370, ss.1153-1163.

Marmot, M. (2015) The Status Syndrome. GB: Blumsburry Publishing.

McGrath, J.J., Matthews, K.A., Brady, S.S. (2006) Individual versus neighborhood socioeconomic status and race as predictors of adolescent ambulatory blood pressure and heart rate. Social Science \& Medicine, 63:1442-1453.

McKeowen,T. (1988) The Orgins of Human disease. Oxford: Basil Blackwell Ltd.

Mendis, S., Puska, P., Norrving, B. (red.) (2011) Global atlas on cardiovascular disease prevention and control. Geneva: World Health Organisation.

Mourad, G., Jaarsma, T., Hallert, C, Strömberg A. (2012) Depressive symptoms and healthcare utilization in patients with noncardiac chest pain compared to patients with ischemic heart disease. Heart \& Lung, 41,5, ss. 446-55. 
Myrtek, M. (2001) Meta-analyses of prospective studies on coronary heart disease, type A personality, and hostility. International Journal of Cardiology, 79, Ss. 245-251.

Nabi, H., Kivimaki, M., De Vogli, R., Marmot, M.G., Singh-Manoux, A. (2008) Positive and negative affect and risk of coronary heart disease: Whitehall II prospective cohort study. British Medical Journal, 337a, ss. 118.

Nabi, H., Hall, M., Koskenvuo, M., Singh-Manoux, A., Oksanen, T., Suominen, S. (2010) Psychosocial and Somatic Symptoms of Anxiety and Risk of Coronary Heart Disease: The Health and Social Support Prospective Cohort Study. Biological Psychiatry, 67, ss. 378-385.

National Institute of Public Health (2009;09)Health on equal terms. Purpose and background to the issues of the National Public Health questionnaire. https://snd.gu.se/en/catalogue/series/national-public-health-survey-healthon-equal-terms [2017-03-24].

National Services Scotland (NHS) (2015). Alcohol consumption and price in Scotland, 2015 (NHS) Health Scotland, 2015. http://www.healthscotland.scot/media/1202/27345-oo-alcoholconsumption-and-price-in-scotland-2015may2016.pdf [2017-06-01]

National Services Scotland (NHS) (2016). Monitoring and Evaluating Scotland's Alcohol Strategy - Final Annual Report. National Services Scotland (NHS) Health Scotland, 2016. http://www.healthscotland.scot/media/1100/mesas-final-annual-report_5780_mar-2016.pdf [2017-06-01]

Newton, J., Briggs, A.D., Murray, C,J., Dicker, D., Foreman, K.J., Wang, H. et al. (2015) Changes in health in England, with analysis by English regions and areas of deprivation, 1990-2013: a systematic analysis for the Global Burden of Disease Study 2013. Lancet, 386, ss. 2257-2274.

Nichols, M., Townsend, N., Scarborough, P., Rayner, M. (2013) Cardiovascular disease in Europe: epidemiological update. European Heart Journal, 34(39), ss. 3028-3034. doi:10.1093/eurheartj/eht356).

Oestreicher Stock, E., Redberg, R. (2012) Cardiovascular Disease in Women. Current Problems in Cardiology, 37, ss. 450-526.

O'Keefw-McCarthy, S. (2009) Women's experience of cardiac pain: a review of the literature. Canadian Journal of Cardiovascular Nursing, 19(2), ss. 3.

Ono, R., Falcao, L.M. (2016) Takotsubo cardiomyopathy systematic review: Pathophysiologic process, clinical presentation and diagnostic approach to

Takotsubo cardiomyopathy. International Journal of Cardiology, 209, ss. 196-205. 
Osler, M., Gerdes, L.U., Davidsen, M., Brönnum-Hansen, H., Madsen, M., Jörgensen, T. et al. (2000) Socioeconomic status and trends in risk factors for cardiovascular diseases in the Danish MONICA population, 1982-1992. Journal of Epidemiology \& Community Health, 54, ss. 108-113.

Panico, S., Mattiello, A. (2010) Epidemiology of cardiovascular disease in woman in Europe. Nutrition, Metabolism and Cardiovascular Diseases, 20, ss. 379-380.

Peltonen, M., Rosen, M., Lundberg, V., Asplund,K. (2000) Social pattering of myocardial infarction and stroke in Sweden: incidence and survival. American Journal of Epidemiology, 151, ss. 238-292.

Perk, J., De Backe, G., Gohlke, H., Granham, I., Reiner, Z., Verschuren, M. et al. (2012) European Guidelines on cardiovascular disease prevention in clinical practice (version 2012): The Fifth Joint Task Force of the European Society of Cardiology and Other Societies on Cardiovascular Disease Prevention in Clinical Practice. Atherosclerosis, 223(1), ss. 1-68.

Pett, M.M., Lackey, N.R., Sullivan, J. (2003) Making sense of factor analysis the use of factor analysis for instrument development in health care research. CA: Thousand Oaks, SAGE.

Picket, K., Pearl, M. (2001) Multilevel analysis of neighbourhood socio-economic context and health outcomes, a critical review. Journal of Epidemiology \& Community Health, 55, ss. 111-122.

Pickett, K.E., Wilkinson, R.G. (2010) Inequality: an under acknowledged source of mental illness and distress. British Journal Of Psychiatry, 197, ss. 426-428.

Pickett, K.E., Wilkinson, R.G. (2015) Income inequality and health: A causal review. Social Science \& Medicine, 128, ss. 316-326.

Polit, D., Beck, C.T. (2008) Nursing Research, Generationg and Assessing Evidence for Nursing Practice, eighth ed. Philadelphia: Lippincott Williams \& Wilkins.

Pride, Y.B., Piccirillo, B.J., Gibson, C.M. (2013) Prevalence, consequences, and implications for clinical trials of unrecognized myocardial infarction. American Journal of Cardiology, 111, ss. 914-918.

Rabinovich L, Brutscher P-B, de Vries H, Tiessen J, Clift J, Reding A. (2009) The affordability of alcoholic beverages in the European Union. European Commission, RAND Corporation, UK, 2009. http://ec.europa.eu/health/ph_determinants/life_style/alcohol/documents/alcohol_rand_en.pdf [2017-06-01] 
Reinier, K., Thomas, E., Andrusiek, D.L., Andrusiek, D.L., Brooks, S.C., Callaway, C.W. et al. (2011) Resuscitation Outcomes Consortium Investigators. Socioeconomic status and incidence of sudden cardiac arrest. Canadian Medical Association Journal , 183(15), ss. 1705-1712.

Rose, G. (1985) Sick individuals and sick populations. International Journal of Epidemiology, 14, ss. 32-38.

Rose, G. (2001) Sick individuals and sick populations (reiteration). International Journal of Epidemiology, 30, ss. 427-432.

Rosengren, A., Hawken, S., Ounpuu, S., Sliwa, K., Zubaid, M., Almahmeed W.A. et al.(2004) Association of psychosocial risk factors with risk of acute myocardial infarction in 11119 cases and 13648 controls from 52 countries (the INTERHEART study): case-control study. Lancet, 364(9438), ss. 953-962. doi:10.1016/So140-6736(04)17019-0.

Rosengren, A., Subramanian, S.V., Islam, S., Chow, C.K., Avezum, A., Kazim, K. et al. (2009) INTERHEART; Educational and risk for acute myocardial infarction in 52 high, middle and low-income countries. Heart, 95, ss. 2014-2022.

Rosenman, R.H., Brand, R.J., Sholtz, R.I., Friedman, M. (1976) Multivariate prediction of coronary heart disease during 8.5 year follow up in the Western colloborative group study. American Journal of Cardiology, 37, ss. 903-910.

Rostila, M. \& Toivanen, S. (2012) Den orättvisa hälsan - om socioekonomiska skillnader i hälsa och livslängd. Stockholm: Liber.

Roth, G.A., Huffman, M.D., Moran, A.E., Feigin, V., Mensah, G.A., Naghavi, M., Murray, C.J. (2015) Global and regional patterns in cardiovascular mortality from 1990 to 2013. Circuation, Oct 27, 132 (17), ss. 1667-1678.

Sapolsky, R. (1994) Why zebras don't get ulcers: A guide to stress, stress-related diseases and coping. New York: WH Freeman.

Schaufeli, W.B., Buunk, B.P. (2003) Burnout: an overview of 25 years of research and theorizing. I Schabracq, M.J., Winnbust, J.A.M., Cooper, C.C. (red.) The handbook of Work and Health Psychology. 2nd ed. UK: Wiely; Wesr Sussex, ss. 383-429.

Schenk-Gustafsson, K. (2008) Det brustna kvinnohjärtat - om kvinnors hjärtkärlsjukdomar, Stockholm: Prisma.

Schlyter, M., André-Petersson, L., Engström, G., Tydén, P., Östman, M. (2011) The impact of personality factors on delay in seeking treatment of acute myocardial infarction. BMC Cardiovascular Disorders, 11, ss. 21.

Schofield, L., Walsh, D., Munoz-Arroyo, R., McCartney, G., Buchanan, D., Lawder, R. et al. (2016) Dying younger in Scotland: trends in mortality and deprivation relative to England and Wales, 1981-2011. Health Place, 40, ss. 105-114. 
Schüle, SA., Bolte, G. (2015) Interactive and independent associations between the socioeconomic and objective built environment on the neighborhood level and individual health. A systematic review of multilevel studies. PLOS One, April $7,10(4)$.

Scottish Health Survey (2011) User Guide. Scottish Centre for Social Research Department of Epidemiology and Public Health, University College London \& The MRC Social and Public Health Sciences Unit, Glasgow.

http://doc.ukdataservice.ac.uk/doc/7247/mrdoc/pdf/7247_shes11_userguide.p df. [2017-03-24]

Shekelle, R.B., Hully, S.B., Neaton JD, Billings, J.H., Borhani, N.O., Gerace, T.A. et al. (1985) MRFIT behavior pattern study. II. Type A behavior and incidence of coronaly heart diasease. American Journal of Epidemiology, 122, ss. 559-570.

Siegrist, J. \& Marmot, M. (red.) (2006) Social inequalities in health :new evidence and policy implications. Oxford : Oxford University Press.

Statistiska Centralbyrån (SCB) (2016) Swedish statistics, 2016. http://www.scb.se/hitta-statistik/statistik-efter-

amne/befolkning/befolkningsframskrivningar/befolkningsframskrivningar/pon $\mathrm{g} /$ tabell-och-diagram/sveriges-framtida-befolkning-2016206o/medellivslangdefter-kon-och-prognos/ [2017-08-02]

Steptoe, A., Kivimäki, M. (2013) Stress and cardiovascular disease: an update on current knowledge. Annual Review of Public Health, 34, ss. 337-354.

Stjärne, M.K., Ponce de Leon, A., Hallqvist, J. (2004) Contextual effects of fragmentation and material deprivation on risk of myocardial infarction - results from the Stockholm Heart Epidemiology Program (SHEEP). International Journal of Epidemiology, 33, ss. 732-741.

Suinn, R.M. (2001) The terrible twos - anger and anxiety. American Psychologist, 56, ss. 27-36.

Sundqvist, K., Malmström, M., Johansson, S.E., Sundquist, J. (2003) Care Need Index, a useful tool for the distribution of primary health care resources. Journal of Epidemiology \& Community Health, 57, ss. 347-352.

Susser, M., Susser, E. (1996) Choosing a future for epidemiology: II from black box to Chinese boxes and eco-epidemiology. American Journal of Public Health, 86, ss. 674-677.

Swedish National Institute of Public Health (2010) Basic Facts of the Swedish Communities, Mortality in Ischemic Heart Disease 2004-2008.

http://app.fhi.se/pxweb/Database/kbf/databasetree.asp_[2010-06-01]

Szeto, H.C., Coleman, R.K., Gholami, P., Hoffman, B.B., Goldstein, M.K. (2002) Accuracy of computerized outpatients diagnoses in a Veterans Affairs general medicine clinic. American Journal of Manage Care, 8, ss. 37-43. 
Theorell, T., Jood, K., Slunga Järvholm, L., Vingård, E., Perk, J., Östergren, P.O. et al. (2016)A systematic review of studies in contributions of the work environment to ischemic heart disease development. European Journal of Public Health, 26, 3, ss. $470-477$.

The Public Health Agency of Sweden (2016) Public Health in Sweden. Yearly Report 2016. www.folkhalsomyndigheten.se/pagefiles/23257/Folkhalsan-i-Sverige2016-16005.pdf [2017-06-01].

The Swedish National Board of Health and Welfare.(2015) Guidelines for treatment of coronary heart disease. Lindesberg: SE:Bergslagens Grafiska.

Tindle, H.A., Chang, Y.F., Kuller, L.H., Manson, J.E., Robinson, J.G., Rosal, M.C. et al. (2009) Optimism, Cynical Hostility, and Incident Coronary Heart Disease and Mortality in the Women's Health Initiative. Circulation, 120(8), ss. 656-662.

Tong, A., Sainsbury, P., Craig, J. (2007) Consolidated Criteria for Reporting Qualitative Research (COREQ): A 32-Item Checklist for Interviews and Focus Groups. International Journal for Quality in Health Care, 19, ss. 349-357. http://dx.doi.org/10.1093/intqhc/mzmo42

Truthmann, J., Busch, M.A., Scheidt-Nave, C., Mensink, G.B., Gosswald, A., Endres, M., et al. (2015) Modifiable cardiovascular risk factors in adults aged 40-79 years in Germany with and without prior coronary heart disease or stroke. $B M C$ Public Health, 15, ss. 701. doi:10.1186/s12889-015-1929-5.

Tunstall-Pedoe, H., Woodward, M., Tavendale, R., A'Brook, R., McCluskey, M.K. (1997) Comparison of the prediction by 27 different factors of coronary heart disease and death in men and women of the Scottish Heart Health Study. British Medical Journal, 315, ss. 722-729.

Van Melle, J.P., de Jong, P., Spijkerman, T.A., Tijssen, J.G., Ormel, J., van Veldhuisen, D.J. et al. (2004) Prognostic association of depression following myocardial infarction with mortality and cardiovascular events: a meta-analysis. Psychosomatic Medicine, 66(6), ss. 814-822.

Watson, D., Naragon-Gainey, K. (2014) Personality, Emotion, and the Emotional Disorders. Clinical Psychological Science, 1, 2(4), ss. 422-442.

Weinehall, L. (2003) The emerging epidemic cardiovascular disease. Scandinavian Journal of Public Health, 61(Supp 1), ss. 5-8.

Weinehall,L. (1997) Partnership for health, on the role of primary health care in a community intervention programme. Diss. Umeå: Umeå University.

Wenger, N.K. (2010) The female heart is vulnerable to cardiovascular disease: emerging prevention evidence for women must inform emerging prevention strategies for women. Circulation Cardiovascular Quality Outcomes, 3(2), ss. 118-119. 
Wennerholm, C., Grip, B., Johansson, A., Nilsson, H., Honkasalo, M-L., Faresjö, T. (2011) Cardiovascular disease occurrence in two close but different social environments. International Journal of Health Geographic, 10:5.

Wennerholm, C., Jern, M., Honkasalo, M-L., Faresjö, T. (2014) Life before the myocardial infarction? A qualitative study of middle-aged women. Health, 6, ss. 2765-2774. DOI: 10.4236/health.2014.62031610.4236

Veronesi, G., Ferrario, M.M., Kuulasmaa, K., Bobak, M., Chambless, L.E., Salomaa, V. et al. (2016) Educational class inequalities in the incidence of coronary heart disease in Europe. Heart, 102, ss. 958-965.

Wilchesky, M., Tamblyn, R.M., Huang, A. (2004) Validation of diagnostic codes within medical services claims. Journal of Clinical Epidemiology, 57, ss. 131-141.

Wilkinson, R. (1997) Health inequalities, relative or absolute material standards? British Medical Journal, 314, ss. 591-595.

Wilkinsson, R. (2005) The impact of inequality - how to make sick societies healthier. London: Routledge.

Wilson, K., Eyles, J., Ellaway, A., Macintyre, S., Macdonald, L. (2010) Health status and health behaviors in neighborhoods. A comparison of Glasgow, Scotland and Hamilton, Canada, Health \& Place, 16(2), ss. 331-338.

Wirehn, A.B., Karlsson, M.H., Carstensen, J.M. (2007) Estimating disease prevalence using a populations-based administrative healthcare database. Scandinavian Journal of Public Health, 35, ss. 424-431.

Wolfe, I., Donkin, A., Marmot, M., Macfarlane, A., Cass, H., Viner, R. (2015) UK child survival in a European context: recommendations for a Countdown Collaboration. Archives of Diseases in Childhood, 100(10), ss. 907-914.

World Health Organization (WHO). (2017) Cardiovascular disease (CVDs), Fact sheet, 2017. http://www.who.int/mediacentre/factsheets/fs317/en [2017-06-01]

World Health Organization (WHO). (2008) Closing the gap in a generation: health equity through action on the social determinants of health. Final report of the Commission of Social Determinations of Health. Genève: World Health Organization.

World Health Organization (WHO). (2009) Women and health: today's evidence tomorrow's agenda. Geneva: WHO Press.

World Heart Federation (2017) Driving non-communicable diseases to the top of the global agenda. https://www.world-heart-federation.org/2017 [2017-08-20]

Vågerö, D. (2006) Where does new theory come from? Journal of Epidemiology \& Community Health, 60, ss. 573-574. 
Yusuf, S., Hawken, S., Õunpuu, S., Dans, T., Avezum, A., Lanas, F. (2004) Effect of potentially modifiable risk factors associated with myocardial infarction I 52 countries (the INTERHEART study): case-control study. Lancet, 9438, ss. 937952.

Zhang, X., Cowling, D.W., Tang, H. (2010) The impact of social norm change strategies on smokers' quitting behaviours. Tobacco Control, 19 (Suppl 1), Ss. 51-55. 


\section{Papers}

The papers associated with this thesis have been removed for copyright reasons. For more details about these see:

http://urn.kb.se/resolve?urn=urn:nbn:se:liu:diva-140934 
Bilaga 1 



\section{Intervjuguide - Kvinnor och hjärtsjukdomar}

\section{Nutiden:}

- Hur ser ditt liv ut nu? Arbetsliv? Är du nöjd? Trivs du?

- Hur vill du att det skall vara?

- Om hjärtsjukdomar

- I familjen?

- Egna besvär - När? Hur?

- Vad har försökt göra med dem?

- Hur har sökt hjälp? Hos vilka?

- Vad har hänt?

1. Varför?

- Får man hjärtbesvär?

- Vad är orsaken/orsakerna?

- Många tänker att det är?

- Stress/levnadsvanor $\mathrm{mm}$ - hur tänker du/din familj/dina vänner?

\section{Bakgrund:}

- Livshistoria

- Berätta om din livshistoria

- Barndomsfamilj, levnadsförhållanden

- "kultur" (där man har formats till den man är i dag) 

Bilaga 2 



\section{Din bakgrund}

1. Vilken är din utbildningsbakgrund?

ㄱ Folkskola 9 år eller mindre

ㄱ 9-årig Grundskola

ㅁ Gymnasium praktiskt inriktad

ㄱ Folkhögskola

$\square$ Gymnasium 2-årigt

ㅁ Gymnasium 3-årigt teoretiskt inriktad

ㅁ Högskolestudier 1 - 3 år

ㄱ Högskolestudier/Universitetsutbildning 3 år eller mer

\section{Hur bor du?}

$\square$ Egen villa/radhus

ㅁ Bostads-/andelsrätt

$\square$ Hyresrätt

$\square$ Inneboende, studentlägenhet/rum

ㄱ Annat

\section{3. a) Med vem delar du bostad?}

D.v.s. bor du tillsammans med under större delen av veckan. Du kan ange flera alternativ.

$\square$ Ingen

$\square$ Föräldrar/syskon

Make/maka/sambo/partner

$\square$ Andra vuxna

$\square$ Barn

b) Hur gamla är de barn som du bor tillsammans med?
ㄱ $0-6$ år
口 7-12 år
13-17 år
ㅁ $\quad 18$ år eller äldre

\section{Hur gammal är du?}

år.

5. Hur lång är du?

Svara i hela centimeter.

cm.

6. Hur mycket väger du?

Svara i hela kilo.

$\mathrm{Kg}$ 
7. Här önskar vi att du mäter och skriver ner Ditt midjemått:

\section{Gör så här:}

Du behöver ett måttband som finns medskickat med enkäten. Det är enklast att mäta midjan där du är som smalast. Om du är rund om magen kan du mäta mitt emellan nedersta revbenet och höftbenet. Stå så avspänt som möjligt med benen lite isär. Ta ett djupt andetag och andas ut precis innan du mäter. Mät sedan utan att dra åt måttbandet.

cm

\section{Hälsa}

8. Hur bedömer du ditt allmänna hälsotillstånd?
$\square$ Mycket bra
$\square$ Bra
$\square$ Någorlunda
$\square$ Dåligt
$\square$ Mycket dåligt

9. Har du någon långvarig sjukdom, besvär efter olycksfall, någon nedsatt funktion eller annat långvarigt hälsoproblem?

$\begin{array}{ll}\square & \mathrm{Ja} \\ \square & \mathrm{Ne}\end{array}$

10. Medför dessa besvär att din arbetsförmåga är nedsatt eller hindrar dig i dina andra dagliga sysselsättningar?
$\square$ Nej, inte alls
$\square$ Ja, i någon mån
$\square$ Ja, i hög grad

11. Kan du springa en kortare sträcka (ca $100 \mathrm{~m})$ ?

$\begin{array}{ll}\square & \mathrm{Ja} \\ \square & \mathrm{Nej}\end{array}$

12. Är du på grund av ditt hälsotillstånd begränsad i någon av följande aktiviteter? Sätt ett kryss på varje rad.
a) Kan du gå upp ett trappsteg utan besvär?
t.ex. stiga på buss eller tåg
$\square \quad \mathrm{Ja} \quad \mathrm{Nej}$
b) Kan du ta en kortare promenad (ca 5 min) i någorlunda rask takt? $\quad \square \quad \mathrm{Ja} \quad \square \quad \mathrm{Nej}$
c) Behöver du hjälpmedel eller hjälp av någon annan person för att förflytta dig utomhus?

$\square \quad \mathrm{Ja} \quad \square \quad \mathrm{Nej}$ 
13. Har du av läkare fått något/några av följande sjukdomar konstaterade/diagnostiserade?
a) Diabetes?
a Nej
ㄱ Ja, men inga besvär
ㄱa Ja, lätta besvär
- Ja, svåra besvär

b) Astma?

$\square \mathrm{Nej}$

$\square$ Ja, men inga besvär

ㄱ Ja, lätta besvär

口 Ja, svåra besvär

c) KOL?

口 $\mathrm{Nej}$

$\square$ Ja, men inga besvär

$\square$ Ja, lätta besvär

Ja, svåra besvär

d) Högt blodtryck?

口 $\mathrm{Nej}$

$\square$ Ja, men inga besvär

$\square$ Ja, lätta besvär

Ja, svåra besvär

14. Har du något/några av följande besvär eller symtom?

a) Värk i skuldror, nacke eller axlar?

$\square \mathrm{Nej}$

$\square$ Ja, lätta besvär

口 Ja, svåra besvär

b) Ryggsmärtor, ryggvärk, höftsmärtor eller ischias?

$\square \mathrm{Nej}$

$\square$ Ja, lätta besvär

$\square$ Ja, svåra besvär

d) Huvudvärk eller migrän?

$\square \mathrm{Nej}$

$\square$ Ja, lätta besvär

Ja, svåra besvär

e) Ängslan, oro eller ångest?

$\square \mathrm{Nej}$

$\square$ Ja, lätta besvär

$\square$ Ja, svåra besvär

\section{f) Trötthet?}

$\square \mathrm{Nej}$

$\square$ Ja, lätta besvär

Ja, svåra besvär

\section{g) Sömnsvårigheter?}

$\square \mathrm{Nej}$

$\square$ Ja, lätta besvär

- Ja, svåra besvär

h) Eksem eller hudutslag?

口 $\mathrm{Nej}$

口 Ja, lätta besvär

ㄱ Ja, svåra besvär 


\section{i) Andfåddhet?}

$\square \mathrm{Nej}$

ㄱ Ja, lätta besvär

ㄱ Ja, svåra besvär

\section{j) Bröstsmärtor?}

$\square \mathrm{Nej}$

ㄱa Jältta besvär

ㄱ Ja, svåra besvär

\section{k) Övervikt, fetma?}

$\square \mathrm{Nej}$

$\square$ Ja, men inga besvär

ㄱ Ja, lätta besvär

- Ja, svåra besvär

l) Har någon/några i din släkt haft hjärtkärlsjukdom, dvs hjärtinfarkt, stroke, kärlkramp? (här kan du kryssa i flera alternativ)



\section{Välbefinnande}

15. Har du de senaste veckorna kunnat koncentrera dig på allt du gjort?

$\square$ Bättre än vanligt

$\square$ Som vanligt

$\square$ Sämre än vanligt

․ Mycket sämre än vanligt

16. Har du de senaste veckorna känt att du kunnat uppskatta det du gjort om dagarna?

$\square$ Mer än vanligt

$\square$ Som vanligt

$\square$ Mindre än vanligt

․ Mycket mindre än vanligt

17. Har du haft svårt att sova på grund av oro de senaste veckorna?

$\square$ Inte alls

$\square \quad$ Inte mer än vanligt

$\square$ Mer än vanligt

$\square$ Mycket mer än vanligt

18. Har du de senaste veckorna kunnat ta itu med dina problem?

$\square$ Bättre än vanligt

$\square$ Som vanligt

$\square$ Sämre än vanligt

$\square$ Mycket sämre än vanligt 
19. Upplever du att du har gjort nytta de senaste veckorna?

$\square$ Mer än vanligt

$\square$ Som vanligt

$\square$ Mindre än vanligt

$\square$ Mycket mindre än vanligt

20. Har du ständigt de senaste veckorna känt dig olycklig och nedstämd?

$\square$ Inte alls

$\square \quad$ Inte mer än vanligt

$\square$ Mer än vanligt

․ Mycket mer än vanligt

21. Har du de senaste veckorna kunnat fatta beslut i olika frågor?

$\square$ Bättre än vanligt

$\square$ Som vanligt

$\square$ Sämre än vanligt

․ Mycket sämre än vanligt

22. Har du de senaste veckorna förlorat tron på dig själv?

$\square$ Inte alls

$\square \quad$ Inte mer än vanligt

$\square$ Mer än vanligt

$\square$ Mycket mer än vanligt

23. Har du ständigt känt dig spänd de senaste veckorna?

$\square$ Inte alls

口 Inte mer än vanligt

$\square$ Mer än vanligt

$\square$ Mycket mer än vanligt

24. Har du tyckt att du varit värdelös de senaste veckorna?

$\square$ Inte alls

$\square \quad$ Inte mer än vanligt

$\square$ Mer än vanligt

$\square$ Mycket mer än vanligt

25. Har du de senaste veckorna känt att du inte kunnat klara dina problem?

$\square$ Inte alls

$\square$ Inte mer än vanligt

$\square$ Mer än vanligt

$\square$ Mycket mer än vanligt

26. Har du på det hela taget känt dig någorlunda lycklig de senaste veckorna?

$\square$ Mer än vanligt

$\square$ Som vanligt

$\square$ Mindre än vanligt

ㅁ Mycket mindre än vanligt

27. Känner du dig för närvarande stressad?

$\square$ Inte alls

ㅁ I viss mån

ㅁ Ganska mycket

Väldigt mycket 
28. Uppfattar du dig som en person med höga krav på dig själv?

$\square$ Ja, absolut

$\square$ Ja, delvis

$\square$ Nej, knappast

29. Upplever du att du har svårt att prioritera dina egna behov?

$\square$ Ja, absolut

$\square \mathrm{Ja}$, delvis

$\square$ Nej, knappast

30. Anser du själv att du är en "pedant"?
$\square$ Ja, absolut
$\square \mathrm{Ja}$, delvis
$\square$ Nej, knappast

31. Upplever du att du har svårt att säga NEJ i kontakten med andra människor eller när någon ber om hjälp?

$\square \mathrm{Ja}$, absolut

$\square \mathrm{Ja}$, delvis

$\square$ Nej, knappast

32. Uppfattar du dig själv som en "duktig flicka" ?

(sätt ett kryss på linjen nedan)

\begin{tabular}{llllllllll}
1 & 2 & 3 & 4 & 5 & 6 & 7 & 8 & 9 & 10 \\
\hline & & & & & & & & & Ja, absolut
\end{tabular}

\section{Läkemedel}

33. Har du under de senaste tre månaderna använt något eller några av följande läkemedel? (Sätt ett kryss för varje läkemedel)
a) Magsårs-/magkatarrsmedicin
b) Medicin mot hjärtbesvär/hjärtsjukdom
c) Diabetesmedicin tabletter/insulin
d) Blodtryckssänkande medicin
e) Sömnmedel/insomningsmedicin
f) Medicin mot depression
g) Lugnande/ångestdämpande medicin
h) Smärtstillande/
inflammationshämmande medicin
i) Blodfettssänkande medicin

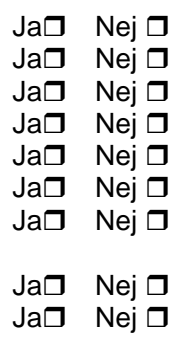




\section{Vårdkontakter}

34. Har du under de senaste tre månaderna besökt eller besökts av någon av följande? (Gäller egna besvär eller sjukdom. Sätt ett kryss på varje rad.)
a) Läkare på sjukhus
$\square \quad$ Nej $\square$ Ja, en gång $\square$ Ja, flera gånger
b) Läkare på vårdcentral,
$\square \quad$ Nej $\square$ Ja, en gång $\square$ Ja, flera gånger privat-/företagsläkare och dyl.
c) Sjuksköterska
$\square \quad$ Nej $\square$ Ja, en gång $\square$ Ja, flera gånger
d) Kurator
$\square \quad$ Nej $\square \quad$ Ja, en gång $\square$ Ja, flera gånger
e) Psykolog
$\square \quad$ Nej $\square$ Ja, en gång $\square$
Ja, flera gånger
f) Sjukgymnast
$\square \quad$ Nej $\square$ Ja, en gång $\square$ Ja, flera gånger
g) Varit inlagd på sjukhus
$\square \quad$ Nej $\square$ Ja, en gång $\square$
Ja, flera gånger

35. Har du under de senaste tre månaderna ansett dig vara i behov av läkarvård men ändå avstått från att söka vård?

$\square \mathrm{Ja}$

$\square \mathrm{Nej}$

\section{Fysisk aktivitet}

36. Hur mycket har du rört och ansträngt dig kroppsligt på fritiden under de senaste 12 månaderna?

Om din aktivitet varierar mellan t.ex. sommar och vinter, så försök att ta ett genomsnitt. (Obs! Kryssa endast $i$ ett alternativ.)

\section{ㄱ Stillasittande fritid}

Rör dig mindre än 2 timmar i veckan.

\section{․ Måttlig motion på fritiden}

Rör på dig under minst 2 timmar i veckan oftast utan att svettas.

$\square$ Måttlig, regelbunden motion på fritiden

Du motionerar regelbundet 1-2 gånger per vecka minst 30 minuter per gång som gör att du svettas.

$\square$ Regelbunden motion och träning I genomsnitt minst 3 tillfällen per vecka. Vardera tillfället varar minst 30 minuter per gång.

37. Hur mycket tid ägnar du en vanlig vecka åt måttligt ansträngande aktiviteter som får dig att bli varm?

ㄷ 5 timmar per vecka eller mer

$\square$ Mer än 3 timmar, men mindre än 5 timmar per vecka

ㅁ Mellan 1 och 3 timmar per vecka

$\square$ Högst en timme per vecka 


\section{Matvanor}

37. a) Hur ofta äter du grönsaker och rotfrukter?

$\square$ dagligen

$\square$ flera gånger i veckan

$\square$ någon gång i veckan

$\square$ mer sällan

b) Hur ofta äter du frukt och bär?

$\square$ dagligen

ㄱ flera gånger i veckan

$\square$ någon gång i veckan

$\square$ mer sällan

c) Hur ofta äter du fikabröd?

$\square$ dagligen

$\square$ flera gånger i veckan

$\square$ någon gång i veckan

$\square$ mer sällan

d) Hur ofta dricker du läsk?

$\square$ dagligen

$\square$ flera gånger i veckan

$\square$ någon gång i veckan

$\square$ mer sällan

e) Hur ofta äter du fisk?

$\square$ dagligen

$\square$ flera gånger i veckan

$\square$ någon gång i veckan

$\square$ mer sällan

f) Hur ofta äter du rött kött?

$\square$ dagligen

$\square$ flera gånger i veckan

$\square$ någon gång i veckan

$\square$ mer sällan

38. Tänker du på vad du äter?

$\square \mathrm{Ja}$

$\square$ Delvis

$\square \mathrm{Nej}$

\section{Rök- och snusvanor}

39. Röker du dagligen?

$\begin{array}{ll}\square & \mathrm{Ja} \\ \square & \mathrm{Nej}\end{array}$

40. Händer det att du röker någon gång då och då?

ㄱ Ja

$\square \quad \mathrm{Nej}$ 
41. Har du tidigare rökt dagligen?

$\square \mathrm{Ja}$

$\square \mathrm{Nej}$

42. Om ja: När slutade du röka?

43. Hur ofta vistas du inomhus i lokaler där andra personer röker eller nyss har rökt? a) I ditt hem

$\square$ Varje dag $\square$ några gånger/vecka $\square$ Några gånger/mån $\square$ Mer sällan eller aldrig

b) På arbetet

$\square$ Varje dag $\square$ några gånger/vecka $\square$ Några gånger/mån $\square$ Mer sällan eller aldrig

\section{Alkoholvanor}

44. Hur ofta dricker du alkohol?

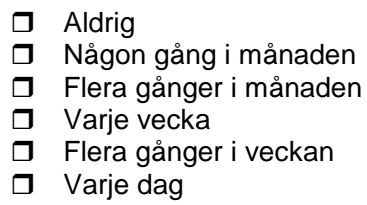

49. Vill du minska din alkoholkonsumtion?

$\square$ Ja, och jag tror att jag klarar det själv
$\square \quad \mathrm{Ja}$, men jag behöver hjälp
$\square \quad \mathrm{Nej}$

\section{Ekonomiska förhållanden}

53. Om du plötsligt skulle hamna i en oförutsedd situation, där du på en vecka måste skaffa fram 15000 kronor, skulle du klara det?

$\square \mathrm{Ja}$

$\square \mathrm{Nej}$

54. Har det under de senaste 12 månaderna hänt att du haft svårigheter att klara de löpande utgifterna för mat, hyra, räkningar m.m.?

$\square$ Ja, vid flera tillfällen

口 Ja, vid ett tillfälle

Nej 


\section{Arbete och sysselsättning}

55. Vilken är din nuvarande sysselsättning?

$\square \quad$ Anställd?

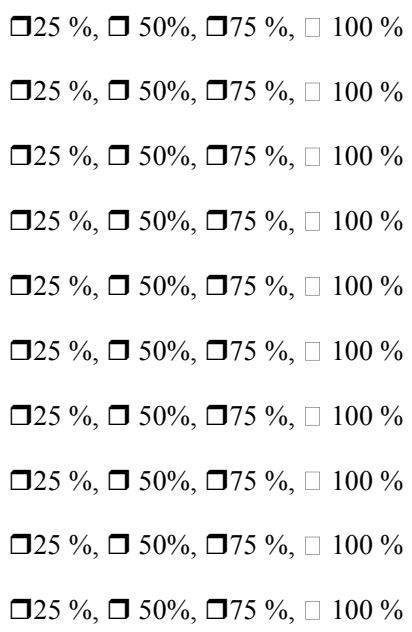

$\square 25 \%, \square 50 \%, \square 75 \%, \square 100 \%$

$\square 25 \%, \square 50 \%, \square 75 \%, \square 100 \%$

$\square 25 \%, \square 50 \%, \square 75 \%, \square 100 \%$

$\square 25 \%, \square 50 \%, \square 75 \%, \square 100 \%$

$\square 25 \%, \square 50 \%, \square 75 \%, \square 100 \%$

$\square 25 \%, \square 50 \%, \square 75 \%, \square 100 \%$

$\square 25 \%, \square 50 \%, \square 75 \%, \square 100 \%$

$\square 25 \%, \square 50 \%, \square 75 \%, \square 100 \%$

$\square 25 \%, \square 50 \%, \square 75 \%, \square 100 \%$

$\square$ Egen företagare

Tjänstledig eller föräldraledig

$\square$ Studerar, praktiserar

$\square$ Arbetsmarknadsåtgärd

$\square$ Arbetslös

$\square$ Ålderspensionär

$\square \quad$ Sjuk-/aktivitetsersättning (förtids-, sjukpensionerad)

$\square \quad$ Långtidssjukskriven (mer än 3 månader)

$\square \quad$ Sköter eget hushåll

$\square \quad$ Annat, nämligen följande

\section{Vilket är/var ditt huvudsakliga yrke?}

Yrke:

Nedan följer några frågor till dig som yrkesarbetar (även du som är sjukskriven ska besvara frågorna).

57. Hur trivs du med dina arbetsuppgifter?

․ Mycket bra

$\square$ Ganska bra

$\square$ Varken bra eller dåligt

$\square$ Ganska dåligt

․ Mycket dåligt

58. Är du orolig för att förlora ditt arbete inom det närmaste året?

$\square \mathrm{Ja}$

$\square \mathrm{Nej}$

59. a) Har du någon sjuk eller gammal närstående som du hjälper med vardagliga sysslor, ser till eller vårdar?

$\square \mathrm{Ja}$

$\square \mathrm{Nej}$

b) Om JA, hur många timmars arbete per vecka innebär detta i genomsnitt för dig?

Antal timmar per vecka. 


\section{Trygghet och Sociala relationer}

60. Händer det att du avstår från att gå ut ensam av rädsla för att bli överfallen, rånad eller på annat sätt ofredad?

$\begin{array}{ll}\square & \mathrm{Ja}, \text { ofta } \\ \square & \mathrm{Ja} \text {, ibland } \\ \square & \mathrm{Nej}\end{array}$

61. Har du under de senaste tre månaderna blivit behandlad/bemött på ett sätt så att du känt dig kränkt?

$\square$ Ja, flera gånger
$\square \quad \mathrm{Ja}$, någon gång
$\square \mathrm{Nej}$

62. Har du någon du kan dela dina innersta känslor med och anförtro dig åt?

$\square \mathrm{Ja}$

$\square$ Ja, för det mesta

$\square \mathrm{Nej}$

63. Kan du få hjälp av någon/några personer om du har praktiska problem eller är sjuk?

T.ex. få råd, låna saker, hjälp med matinköp, reparationer etc.

$\square \mathrm{Ja}$, alltid

$\square \mathrm{Ja}$, för det mesta

$\square$ Nej, för det mesta inte

$\square$ Nej, aldrig

64. Tycker du att man i allmänhet kan lita på de flesta människor?

$\square \mathrm{Ja}$

$\square \mathrm{Nej}$

65. Vilket förtroende har du för följande institutioner/politiker i samhället?
a) Sjukvården
$\square$ Mycket stort $\square$
b) Äldreomsorgen
$\square$ Mycket stort $\square$
c) Barnomsorgen
d) Skolan
Mycket stort $\square$
Ganska stort $\square$ Inte särskilt stort $\square$ Inget alls $\square$ Har ingen åsikt
Ganska stort $\square$ Inte särskilt stort $\square$ Inget alls $\square$ Har ingen åsikt
$\square$ Mycket stort $\square$ Ganska stort $\square$ Inte särskilt stort $\square$ Inget alls $\square$ Har ingen åsikt
e) Polisen
$\square$ Mycket stort $\square$ Ganska stort $\square$ Inte särskilt stort $\square$ Inget alls $\square$ Har ingen åsikt
f) Socialtjänsten
$\square$ Mycket stort $\square$ Ganska stort $\square$ Inte särskilt stort $\square$ Inget alls $\square$ Har ingen åsikt
g) Arbetsförmedlingen
$\square$ Mycket stort $\square$ Ganska stort $\square$ Inte särskilt stort $\square$ Inget alls $\square$ Har ingen åsikt
h) Försäkringskassan
$\square$ Mycket stort $\square$ Ganska stort $\square$ Inte särskilt stort $\square$ Inget alls $\square$ Har ingen åsikt i) Politiker
$\square$ Mycket stort $\square$ Ganska stort $\square$ Inte särskilt stort $\square$ Inget alls $\square$ Har ingen åsikt j) Fackföreningarna
$\square$ Mycket stort $\square$ Ganska stort $\square$ Inte särskilt stort $\square$ Inget alls $\square$ Har ingen åsikt 
66. Hur ser du på din framtid?

ㅁ Mycket hoppfull

$\square$ Ganska hoppfull

․ Varken hoppfull eller dyster

$\square$ Dyster

Mycket dyster

67. Har du något ytterligare som du vill framföra är du välkommen att skriva det här nedan:

TACK FÖR ATT DU TOG DIG TID ATT FYLLA I ENKÄTEN!

Skicka enkäten i det bifogade svarskuvertet. 